This is an author produced version of a paper published in Advances in Ecological Research.

This paper has been peer-reviewed but may not include the final publisher proof-corrections or pagination.

Citation for the published paper:

Martin, E.A. et al. (2019) Assessing the resilience of biodiversity-driven functions in agroecosystems under environmental change. Advances in Ecological Research. Volume: 60, pp: 59-123. http://dx.doi.org/10.1016/bs.aecr.2019.02.003.

Access to the published version may require journal subscription. Published with permission from: Elsevier.

Standard set statement from the publisher:

(C) Elsevier,2019 This manuscript version is made available under the CC-BY-NC-ND 4.0 license http://creativecommons.org/licenses/by-nc-nd/4.0/

SLU publication database, http://urn.kb.se/resolve?urn=urn:nbn:se:slu:epsilonp-101521 
1

2

6

7

8

9

10

11

12

13

14

15

Cite as:

Martin, E.A., Feit, B., Requier, F., Friberg, H., Jonsson, M., 2019. Assessing the resilience of biodiversity-driven functions in agroecosystems under environmental change. Advances in Ecological Research 60, 59-123. https://doi.org/10.1016/bs.aecr.2019.02.003

\section{Assessing the resilience of biodiversity-driven functions in agroecosystems under environmental change}

\section{* Department of Animal Ecology and Tropical Biology, Biocenter, University of Würzburg, Am} Hubland, 97074 Würzburg, Germany.

† Department of Ecology, Swedish University of Agricultural Sciences, PO Box 7044, 75007 Uppsala, Sweden

‡ Department of Forest Mycology and Plant Pathology, Swedish University of Agricultural Sciences, PO Box 7026; 75007 Uppsala, Sweden.

${ }^{1}$ Corresponding author. Email: emily.martin@uni-wuerzburg.de, phone: +499313183876. 


\section{$34 \quad$ Abstract}

Predicting the resilience of biodiversity-driven functions in agroecosystems to drivers of environmental change $(E C)$ is of critical importance to ensure long-term and environmentally safe agricultural production. However, operationalizing resilience of such functions is challenging, because conceptual approaches differ, direct measures are difficult, and the validity and interpretation of existing indicators are unclear. Here, we (1) summarize dimensions of resilience that apply in agroecosystems, and the disturbances they are subject to under EC. We then (2) review indicators of the resilience of biodiversity-driven functions in agroecosystems, and their support in theoretical and empirical studies. (3) Using these indicators, we examine what can be learned for the resilience of these functions to drivers of EC, focussing on the ecosystem services of biological pest control, biological disease control in soil and pollination. We conclude (4) that research into the resilience of these services is still in its infancy, but novel tools and approaches can catalyse further steps to assess and improve the resilience of biodiversity-driven agroecosystem functions under EC.

\section{Keywords}

Biological pest control, biological disease control, pollination, persistence, engineering resilience, ecological resilience 
58 Table of Contents

59 Introduction

60 Section 1: The concept of resilience as applied to biodiversity-driven functions in agroecosystems 6

611.1 Definitions 6

621.2 Spatial, temporal and organizational scales of disturbance: resilience to what?

63 Section 2: The link between indicators and resilience of agroecosystem functions 9

642.1 Indicators of resilience based on measures of biodiversity 10

$\begin{array}{lll}65 & 2.2 \text { Other indicators of resilience } & 19\end{array}$

66 Section 3: Resilience of agroecosystem functions to environmental change 21

$\begin{array}{lll}67 & 3.1 \text { Biological pest control } & 21\end{array}$

683.2 Plant disease suppression in soil 29

693.3 Crop pollination $\quad 35$

70 Section 4: Operationalizing resilience: a critique and steps ahead 42

714.1 Conceptual hurdles and technical challenges 44

724.2 Going beyond: novel approaches to measuring resilience under environmental change 45

734.3 Summary and conclusion: knowledge gaps and future needs 48 


\section{Introduction}

Characterizing and supporting the ability of Earth's ecosystems and their functions to persist, recover and adapt in the face of environmental change $(E C)$ is a major research agenda of the $21^{\text {st }}$ century (Steffen et al., 2018). In agroecosystems, human-environment interactions drive the provision of functions and services - such as crop yields - that are essential for the maintenance of contemporary human societies. However, just as other ecosystems worldwide, agroecosystems are subject to intensifying drivers of environmental change, which are likely to affect their ability to maintain functions over the long term (Tylianakis et al., 2008). Anticipating and preventing the loss of function in agroecosystems is made pressing by immediate, cascading, and potentially catastrophic impacts on global human food security, health, energy, and socio-economic stability as well as on the broader environment (Cabell and Oelofse, 2012; Foley et al., 2011; Wheeler and Braun, 2013).

Key functions provided by agroecosystems include pollination and biological control of pests and diseases. Because they directly influence several aspects of crop productivity, these functions represent ecosystem services with particularly critical impacts on human well-being, most notably human food security (Klein et al., 2007; Millennium Ecosystem Assessment, 2005; Oerke, 2006). In contrast to functions mainly driven by interactions between crops and their abiotic environment (e.g., water regulation, soil retention), pollination, pest and disease control are strongly biodiversitydriven, i.e. the presence and structure of service-providing communities such as pollinators and natural enemies determine service provision, contribution to crop yield and nutritional quality of crops (Bommarco et al., 2012; Pywell et al., 2015). In addition to their key contribution to yields, pest and disease control by natural enemies or antagonistic microorganisms represents an alternative management strategy that could limit environmental externalities and negative feedback loops associated with the use and over-use of synthetic pesticides in agriculture (Bommarco et al., 2013; Lechenet et al., 2017). However, while our understanding of the patterns of biodiversity underlying 
these functions is steadily increasing, the scientific field of predicting biodiversity-driven services in agroecosystems is in many respects still in its infancy (Karp et al., 2018; Tscharntke et al., 2016).

Resilience represents the ability of a system to maintain or recover its functioning, structure and overall identity in the face of changes in environmental conditions (Fig. 1) (Folke et al., 2010; Walker et al., 2004). If resilience of a system is low, disturbances may cause it to pass a threshold or tipping point, after which nonlinear regime shifts may occur (Scheffer et al., 2015). Though often elusive, approaches to quantify and predict the resilience and proximity to tipping points of ecological and social-ecological systems under EC have been fast developing in systems from aquatic, to rangelands, to global plant-pollinator networks (Dakos et al., 2015; Jiang et al., 2018; Sasaki et al., 2015; Sterling et al., 2017). In agroecosystems, such approaches (Angeler and Allen, 2016; Döring et al., 2013; Oliver et al., 2015a; Peterson et al., 2018; Standish et al., 2014) are however only sparsely reflected in the available literature (Vandermeer, 2011). For example, in a review of studies on ecological thresholds of change (Sasaki et al., 2015), agroecosystems were represented in less than $2 \%(2 / 147)$ of all studies published until 2013. More broadly, while resilience research in agroecosystems has focussed to some extent on the maintenance of yields at the field scale (e.g. Döring et al., 2013; Peterson et al., 2018), few studies have explicitly examined the resilience of biodiversity-driven functions and services to contemporary drivers of EC (Donohue et al., 2016; Oliver et al., 2015a). To date, the great majority of studies have used the effects of disturbance on farmland biodiversity as proxies to evaluate the resilience of biodiversity-driven functions (e.g. Karp et al., 2011; Oliver et al., 2015b). However, despite strong theoretical underpinnings and practical benefits of such proxies, the link between actual resilience of agroecosystem functions and the variety of resilience indicators based on biodiversity or other aspects has rarely been demonstrated (Angeler and Allen, 2016; Egli et al., 2018). 
agroecosystem functioning under EC. We focus on the biodiversity-driven functions and ecosystem services of pollination, biological pest control and biological disease control in soils. After (1) defining the concept of resilience as applied to agroecosystems and the nature and scales of disturbances that affect them, we (2) identify how resilience has been measured in these systems and review which available indicators are demonstrated to link to the resilience of biodiversity-driven functions in agroecosystems (from here on termed agroecosystem functions). We then (3) provide a narrative review of what can be learned from available measures and indicators before (4) highlighting current challenges and novel approaches with the potential to push resilience assessment of agroecosystem spatiotemporal complexity.

Section 1: The concept of resilience as applied to biodiversity-driven functions in agroecosystems

\subsection{Definitions}

Resilience has been defined in a multitude of ways across disciplines and systems (Carpenter et al., 2001; Peterson et al., 2018) leading to considerable breadth for its practical implementation (Donohue et al., 2016; Mori, 2016). To operationalize resilience in the context of this review, we consider three related meanings that have been applied or are relevant in agroecological science (Fig. 1) (Angeler and Allen, 2016; Donohue et al., 2016; Egli et al., 2018). (i) Persistence is the ability of a system to maintain its function under stress. (ii) Engineering resilience is the ability of a system to return to its previous state (bounce back) after a disturbance, as reflected e.g. by its speed (or rate) of recovery to the previous state. (iii) Ecological resilience is the extent of disturbances a system can absorb before reorganizing into a different state with different functioning, structure, 
identity and feedbacks (see also Walker et al., 2004 and Folke et al., 2010 for a detailed definition of ecological resilience).

These definitions differ in their focus on (i) the maintenance of an acceptable degree of

functioning under stress, where time may or may not be explicitly incorporated; (ii) the recovery of functioning after stress, with emphasis on a temporal dimension; and (iii) the existence of threshold disturbance levels associated with the intensity of stress. All three definitions have implications for the measurement and applicability of resilience in agroecosystem management (Sasaki et al., 2015), for the interpretation of underlying mechanisms, and lead to widely differing approaches in empirical and theoretical research. We thus employ these definitions throughout and classify existing approaches into each dimension of resilience.

Resilience (persistence, engineering or ecological resilience) can be brought about by a system or a function's properties of recovery (the ability to bounce back, e.g. by reorganizing after disturbance) or resistance (the ability to withstand disturbance without change; Egli et al., 2018; Hodgson et al., 2015; Oliver et al., 2015a). In some cases, rapid recovery may be interpreted as resistance if observed at wider time steps than the speed of recovery (Oliver et al., 2015a). The extent to which a function is able to persist under disturbance depends on both its properties of recovery and resistance (Fig.1a). In contrast, a function's engineering resilience depends on its ability to recover from disturbance (Fig.1b). Both definitions are linked to the concept of ecological stability under its definition by Holling (1973) and in its extensive use in the literature on e.g. diversity-stability relationships (Mori, 2016). However, ecological stability also includes the notion of the constancy of a system in space or time (i.e., its lack of variability; Donohue et al., 2016; Grimm and Wissel, 1997). To refer to systems that vary in space or time, we here use the term 'variability' (as opposed to 'invariability' for a system that does not change; Egli et al., 2018). Importantly, in 
and growth (Vasseur et al. 2013), variability of functions in space or time may be precisely what allows them to recover from and/or resist disturbances (Mori, 2016), thereby exhibiting one or multiple dimensions of resilience (Angeler and Allen, 2016; Egli et al., 2018).

\subsection{Spatial, temporal and organizational scales of disturbance: resilience to what?}

Disturbance is one of the key feature of many agroecosystems, which can be seen as mosaics of repeatedly and differentially disturbed patches through space and time. In agroecosystems, disturbance takes place from the scale of soil aggregates to whole landscapes and biogeographical realms; from instantaneous to decade-long effects; and from individual organisms to whole communities and networks. The multiscale nature of disturbances, and more generally of the variables influencing functions in agroecosystems, means that any given system is affected simultaneously by fast (small-scale) variables, and by slow (large-scale) ones that change much more gradually. Formally, disturbances can be characterized in addition to their spatiotemporal scale in terms of magnitude, frequency, duration, and variability or directionality of change in space and time (Donohue et al., 2016). 'Pulses' or 'acute' disturbances occur more or less instantaneously, but may be distributed over time as discrete environmental fluctuations. 'Press' or 'chronic' disturbances represent sustained, long-term changes (Donohue et al., 2016; Peterson et al., 2018; Sasaki et al., 2015).

Similar to other systems, agroecosystems are affected by globally relevant 'fast' and 'slow' variables (Biggs et al., 2015), such as competition by invasive species, extreme climate events or gradual temperature increases under climate change (e.g. as reviewed by Sasaki et al., 2015). However, a wide range of disturbances relates particularly to agricultural intensification and land use change, with scales that are highly specific to agroecosystems and their management (Peterson et al., 2018). In Fig. 2, we summarize the types of disturbance that can occur in agroecosystems and their spatial and temporal scale of effect. We focus on disturbances whose nature, magnitude or frequency are 
under the direct influence of physical drivers of terrestrial EC as defined by e.g. Sala et al. (2000), including particularly disturbances associated with land use change, climate change, and biotic invasions. As such, these disturbances reflect the impact of EC drivers at the level of agroecosystems. Their effects on biodiversity and associated functions occur both within fields and across whole landscapes, and include disturbances associated with direct management of fields and habitats (tilling, harvesting, pesticide application, changes in crops planted and rotations, changes in field sizes), as well as less controlled (less predictable) events such as extreme weather, outbreaks of pests and diseases or other invasions. Under EC, the directionality of these disturbances may be fixed (e.g. global temperature increases) or may be subject to differences according to regional factors and regulations, as in the case of opposing trends of land use intensification vs. abandonment in different regions and systems (van Vliet et al., 2015).

\section{Section 2: The link between indicators and resilience of agroecosystem functions}

To really understand the resilience of agroecosystem functions, we would ideally want to assess both resilience of the function itself and the biodiversity underpinning it in relation to a disturbance. In some situations this is feasible, such as when assessing persistence against certain acute or chronic disturbances occurring at local or landscape scales (Figure 2). However, in other cases, due to inherent difficulties of measuring the resilience of functions (see section 4 below; Egli et al., 2018), indicators based on the state of biodiversity have been employed to infer the resilience of functioning. Indeed, developing sets of surrogates or indicators is often seen as a more practicable approach to assessing resilience 'than trying to measure resilience itself' (Cabell and Oelofse, 2012; Darnhofer et al., 2010).

In this section, we summarize major indicators of resilience for biodiversity-driven functions in agroecosystems. For each indicator, we examine how and why it should affect function resilience 
and to what extent this link has been demonstrated in empirical and theoretical literature. We identify two broad categories of indicators for biodiversity-driven function resilience (Table 1): (1) indicators based on the state of measures of biodiversity, (2) indicators based not on biodiversity, but on statistical or structural properties of agroecosystems and agroecosystem functions.

\subsection{Indicators of resilience based on measures of biodiversity}

\section{Species richness}

Biodiversity-based indicators of function resilience are founded on the premise that components of biodiversity influence how associated functions are affected by disturbances. Among these, the species richness of communities has historically been examined as a key indicator of resilience of ecosystem functioning (Hooper et al., 2005, 2012). The idea that species richness can contribute to the resilience of ecosystem functions under disturbance or global change is based on the concept of a diversity of responses to disturbance among species (Elmqvist et al., 2003). Due to species-specific responses to disturbance, individual species within a community are likely to be affected differently by environmental change, depending, for example, on climatic tolerance, drought resistance, or resource requirements (Chapin et al., 1997; Naeem and Wright, 2003). With every additional species in a community, the likelihood increases that some species continue to provide a service when others are lost or reduced in effectiveness because of changes in their environment, through a statistical 'portfolio' effect (see functional redundancy below; Biggs et al., 2015; Peterson et al., 1998). The importance of high species richness for function resilience has been demonstrated in empirical and theoretical settings most frequently for plant productivity (Balvanera et al., 2006; Hooper et al., 2005; Isbell et al., 2015; Yachi and Loreau, 1999). However, recognition has risen that species richness per se does not imply function resilience, because species-rich systems may have similar responses to disturbances. In addition, the loss of species is non-random when associated with a particular disturbance, thus species with similar responses may be affected disproportionately, rather than species with different responses being affected equally by 
disturbance (Elmqvist et al., 2003; Mori et al., 2013). Further, classic metrics of taxonomic diversity provide little to no information about probable mechanistic links between species richness and function resilience, as they lack information about the relative importance and interactions of individual species and thus treat every species as equally important for the provision of a function (Cadotte et al., 2011; Gagic et al., 2015; McGill et al., 2006). Yet, the importance of a species' contribution in comparison with others in a community depends on species-specific functional traits ('effect' traits) related to their impact on ecosystem function. Losing a species of high importance will have a stronger effect on the provision and resilience of a service than the loss of a less important species. Consequently, recent studies have progressed from examining taxonomic diversity, to assessing further indicators of function resilience including the presence of key species or functional groups, functional diversity, redundancy and response diversity.

Presence of key species or functional groups

The presence or absence of key species or functional groups providing a particular function may drive both provision and resilience of the function (i.e. the functional identity hypothesis; e.g. Grime, 1998). In this case, the loss of key functional groups in response to disturbance may lead to a collapse of functioning. Theoretically, the consequences of the number of species removed from a system have been shown to depend on the functions those species perform in the system (Dunne et al., 2002). Empirically, extinction or lack of specialist pollinators has led to a collapse of pollination services and costly re-organization through hand pollination to maintain any amount of production, as in the case of vanilla but also apple production in Southern and Central Asia (Anderson et al., 2011; Garibaldi et al., 2009; Partap and Ya, 2012). Other examples include the necessary presence of avian frugivores to maintain seed dispersal, as shown in a natural experiment where frugivores were extirpated on one of two islands (Caves et al., 2013); and the importance of an insectivorous bird species for persistence of biological pest control in cacao (Maas et al., 2015). In soils, resilience (persistence or engineering resilience) of disease suppression may be due to the effect of one or a 
275 few groups (species or isolates) of organisms that are antagonists to the pathogen or active in disease suppression in other ways (Weller et al., 2002).

Functional diversity measures the number or diversity of functionally disparate species or properties of a community. It is assessed through a variety of indices, such as functional evenness and functional divergence that have been found to be better predictors of ecosystem functioning than species richness (Gagic et al., 2015). Several mechanisms are thought to underlie the importance of functional diversity for resilience of functioning: (1) High functional diversity may, through sampling effects, lead to the presence of functional groups with key roles for functioning (see above). (2) In agroecosystems, high functional diversity may enable communities providing a given function to be effective in a range of crops with different traits and management (i.e. the functional complementarity hypothesis; Díaz and Cabido, 2001; Gagic et al., 2015). Although direct 'trait-matching' of crops and service providers has been shown to be more important than functional trait diversity for current provision of pollination services (Garibaldi et al., 2015), high functional diversity may represent essential insurance for resilience of functions to changes in the portfolio of planted crops, and/or to increased diversity of planted crops (as promoted by the European CAP Greening pillar; European Commission, 2016). (3) Because high functional diversity is linked to high occupation of niche space, this indicator may imply buffering against invasions of alien species and/or the addition of new functional groups. For example, disease suppression in soil can be related to unspecific competition for niche space from soil microorganisms (Termorshuizen et al., 2006). Further, ecosystems with low functional diversity are generally considered more prone to invasion by new species than functionally rich ecosystems (Elton, 1958; Levine et al., 2004). In line with this, functionally diverse soil bacterial communities have been found to be more resistant to invasion by exotics, including plant pathogens (Eisenhauer et al., 2013; Irikiin et al., 2006; Matos et al., 2005; van Elsas et al., 2012; Wei et al., 2015), as has the productivity of functionally diverse 
grassland plant communities (Fargione and Tilman, 2005). These effects have been explained by a

301

302

303

high number of species interactions and intense competition for niche space. However, further evidence for the importance of functional diversity and complementarity for resilience of functions is currently lacking.

\section{Functional redundancy and response diversity}

The combination of functional redundancy and response diversity, respectively, guarantees that many species are able to provide a given function, and that they respond in different ways to disturbance (Elmqvist et al., 2003; Mori et al., 2013; Oliver et al., 2015a). Currently, these measures are considered major drivers of the resilience of ecosystem services to disturbance. In contrast to species complementarity and niche specialisation (Poisot et al., 2013), functional redundancy increases with the level of similarity, or functional niche overlap, between species in a community (Fonseca and Ganade, 2001; Naeem, 1998; Pillar et al., 2013). Ecological theories predict that communities with high functional redundancy can reduce the impact of loss of species on service provision (portfolio effect) or of species that experience a population decline as a result of global change (insurance hypothesis) (Hooper et al., 2005; Thibaut and Connolly, 2013). In recent years, an increasing number of studies have investigated the importance of functional redundancy for the resilience or variability of functional groups and ecosystem services under disturbance and change. For instance, Hallett et al. (2017) showed that pollination by wasps can effectively compensate for experimental removal of bumblebees, and Sanders et al. (2018) found that low trophic redundancy can lead to cascades of secondary extinctions and decreased persistence of parasitism following the removal of single parasitoid species. For the functioning of soils, there is a consensus that 'general functions' based on the performance of generalist species (or genotypes), like organic matter decomposition, are more resistant to disturbances than specific functions based on the action of specialist species, like nitrification (Deng, 2012; Griffiths and Philippot, 2013). This difference can be attributed to the observation that general functions are maintained by a wide range of redundant 
microorganisms, while specific functions are maintained by specific groups including fewer redundant species (Griffiths et al., 2001).

However, functional redundancy in itself is insufficient to ensure the resilience of functioning. A diversity of responses to disturbance and environmental change within redundant functional groups is seen as an additional necessary component (Elmqvist et al., 2003). Response diversity of ecosystem function providers in relation to environmental conditions enables compensation and spatiotemporal complementarity between species and individuals providing a particular function (Mori et al., 2013). Response diversity ensures that species with the same or a similar set of functions together contribute to functioning by being able to perform under varying environmental conditions, thereby potentially decreasing the variability of the function over time and increasing its resilience to disturbances. Different responses and sensitivity of species, and of individuals within species, to environmental change can be driven by: variation in inter- and/or intraspecific genetic makeup, phenotypic plasticity, and intrinsic growth rates (Oliver et al., 2015a). In a flexible modelling framework, Norberg et al. (2001) demonstrated theoretically that response diversity increases the persistence of functioning under disturbance by enhancing its capacity for resistance. Empirically, field studies below-ground have shown that selected isolates of microorganisms, applied as augmentative biocontrol to soil or plants to control diseases, can be highly effective in species-poor environments (e.g. in the laboratory or in otherwise sterile soil) but less or ineffective under field conditions (Alabouvette et al. 2006a; Cook 1993). One way to find strategies that are effective across a range of temperatures and soil types is to combine biocontrol agents with different environmental preferences (Elead et al., 1994; Guetsky et al., 2001). Aboveground, the importance of frugivore response diversity for persistence of seed dispersal has been demonstrated (Farwig et al., 2017; González-Varo et al., 2017; Moreira et al., 2017). However, empirical evidence of the effects of response diversity on the resilience of crop-associated functions such as pollination is still limited and ambiguous (Rader et al., 2013; Cariveau et al. 2013; Stavert et al. 2018). Importantly, the benefits of response diversity and functional redundancy for function 
resilience in crops may depend on the type of disturbance considered (Balvanera et al., 2006). In addition, detecting the importance of these indicators may hinge on considering the full pool of organisms providing a function irrespective of provenance or specialisation (Stavert et al., 2018).

relationship between species' response and effect traits, are closely related to the above concepts of functional redundancy and response diversity. Cross-scale resilience is obtained when species or functional groups respond to disturbances at different spatial or temporal scales (Angeler and Allen, 2016; Elmqvist et al., 2003; Peterson et al., 1998). Similarly to the mechanisms of response diversity, cross-scale resilience implies risk-spreading of disturbance effects across scales (instead of between species). This benefits resilience by increasing functions' resistance to disturbances. In addition, due to nestedness of scales within each other, species only affected by disturbance at one scale can be recruited from other scales if they are mobile enough (e.g. landscape or regional species pools) and can thus perform functions at the disturbed scale, leading to resilience through recovery of functioning. Species able to enact such transfers can be considered mobile link organisms (see further definition below) contributing to spatial resilience (Allen et al., 2016). The effectiveness of function recovery across scales may depend on relative patterns of alpha and beta-diversity of functionally redundant mobile link species, e.g. consumers (Tscharntke et al., 2008a, 2012). However, few studies to date have examined the links between cross-scale diversity patterns in agroecosystems and function resilience. One study examining variability of wasp and bee parasitism over time (Tylianakis et al., 2006), found that temporal variation in parasitoid alpha diversity, but not high beta-diversity, led to less variable parasitism. However, positive effects of different responses of organisms between scales have been found outside agroecosystems, for instance on the persistence of avian spruce budworm predation (Holling, 1988) and recently for the recovery of coral reefs (Nash et al., 2016). In both examples, body size of predators was used as a proxy to infer 
differences in scales of responses of organisms to disturbance. In agroecosystems, data on body size of function providers is available for many taxa (e.g. carabids, staphylinids, spiders, bees, butterflies and moths; Boetzl et al., 2018; Duflot et al., 2014; Gossner et al., 2015; Öckinger et al. 2010; Williams et al. 2010). Approaches for cross-scale comparisons of (functional) diversity patterns are also well developed (e.g. Martin et al., 2016; Steffan-Dewenter et al., 2002). However, studies that explicitly link scale-dependent species' responses to the resilience of agroecosystem functions are lacking. In this context, research testing the 'intermediate landscape hypothesis' (Tscharntke et al., 2012) may represent a key step forward by showing that sufficient species pools at the landscape scale can compensate for disturbances or lack of resources at a local scale (e.g. Concepción et al., 2012; Jonsson et al., 2015).

Negative co-variation occurs when the abundance of pairs of species providing the same function is negatively correlated, due to either competition or variation in their response to environmental factors (Elmqvist et al., 2003). Similarly to response diversity, this indicator should lead to persistence of functioning through the continued performance of different species under disturbance (Hooper et al., 2005). Negative co-variation has rarely been found to occur in real communities as shown in several long term and/or cross-taxonomic studies (Houlahan et al., 2007; Karp et al., 2011; Valone and Barber, 2008), and thus appears not to be a particularly useful indicator of the resilience of functioning. However, for example if there is strong competition between exotic and native species, such patterns may nevertheless occur and lead, counter-intuitively, to exotic species contributing to enhanced resilience (Stavert et al., 2018).

In contrast, the nature of the relationship between effect traits and response traits of organisms has been introduced and is gaining momentum as a likely indicator of resilience (Díaz et al., 2013; Oliver et al., 2015a; Standish et al., 2014; Suding et al., 2008). Effect traits are traits of organisms that determine their effects on a given function (e.g. consumption rates for predators). 

effect traits of organisms are correlated, then the loss of a response group after a disturbance implies the loss of the corresponding effect on function, even if other responses occur in the community. By contrast uncorrelated response and effect traits imply a balanced distribution of effect traits among responses of the community, and thus a decoupling between the vulnerability of functioning and the loss of particular response groups (Oliver et al., 2015a; Standish et al., 2014; Suding et al., 2008). Although still rarely examined in agroecosystems or explicitly linked to the persistence of agroecosystem functions (Díaz et al., 2013; Suding et al., 2008), correlated response and effect traits have been shown to cause a disruption of functioning under disturbance in the cases of both pollination and dung burial (Larsen et al., 2005).

Mobile links and biological legacies

legacies is seen as a crucial element for resilience of biodiversity-driven functions in agroecosystems, due to the spatiotemporal patchiness of these systems in terms of both structure and disturbance patterns (Folke et al., 2004; Lundberg and Moberg, 2003). Mobile link organisms represent species or individuals able to recolonize patches after a disturbance. Biological legacies, in contrast, remain in disturbed patches and form sources of regrowth. Because mobile link organisms effectively drive the transfer and recovery of functions through space, they are likely to constitute the key biological mechanism underlying why structural measures of 'spatial resilience' (sensu Allen et al., 2016), such as landscape heterogeneity or autocorrelation (the degree of aggregation of landscape patches), can influence the resilience of biodiversity-driven functions. Indeed, agricultural landscape heterogeneity represents a key factor of species' mobility (Fahrig et al., 2011; Schellhorn et al., 2014). Although many mobile link species are essential providers of valued services (see above paragraph: Presence of key species or functional groups), others such as mobile pests or invasive species often promote undesirable agroecosystem states and 'disservices' (Lundberg and Moberg, 
2003; Standish et al., 2014). This is in spite of disturbances that aim at their elimination such as the use of pesticides against agricultural pests (Krauss et al., 2011). Particularly above-ground, the provision and resilience of pollination and biological pest control are contingent on the ability of pollinators and natural enemies to recolonize fields at appropriate phenological stages after planting, overwintering, or punctual destructive treatments during the growth season (pesticide application, tillage, mowing) (Schellhorn et al., 2015; Tscharntke et al., 2012). The mobility and dispersal ability of organisms enables not only recolonization for recovery of functioning in fields after disturbance, but also the survival of organisms outside fields for the duration of the disturbance, provided appropriate 'refuge' habitats and/or resources are within reach in the surrounding landscape (Bianchi et al., 2006; Schellhorn et al., 2014, 2015).

\section{Interaction network complexity}

In addition to previous indicators, the structure of interaction networks is also considered to be important for the ability of communities to withstand disturbance. Particularly the degree of nestedness, modularity and connectance of networks are expected to play a role in the resilience of network functions (Biggs et al., 2015; Tylianakis and Morris, 2017). In soils, this is particularly relevant when faced with the invasion of species, including plant pathogens. Soil communities with low nestedness and high connectance have been shown to resist pathogen invasion better than communities with low connectance (Wei et al., 2015). This could be explained by a more efficient use of resources in highly connected microbial communities, leading to a more intense competition for resources and reduced saprotrophic growth of the invading pathogen (Case, 1990; Wei et al., 2015). Theoretically, resource use or trophic complementarity of communities has been shown to be an important driver of the persistence of functioning, e.g. in the case of plant productivity (Poisot et al., 2013). In modelled plant-pollinator networks, high connectance and/or nestedness are shown to increase the ability of communities to avoid collapse, persist and recover after disturbance (Lever et 
451 function itself, particularly in crops, remain unclear (Tylianakis and Morris, 2017). These are likely to depend on the effectiveness of trait-matching between pollinators and crops (e.g. Fontaine et al., 2005), which has yet to be integrated into recent modelling approaches (Bartomeus et al., 2016; Garibaldi et al., 2015). Theoretical frameworks provided evidence that in antagonistic networks (e.g. predator-prey), in contrast to mutualistic ones, modularity and low connectance foster community persistence and recovery (Thébault and Fontaine, 2010). However, the consequences for persistence of functioning itself also remain unclear (Tylianakis and Morris, 2017). For example, Macfadyen et al. (2009) found no link between the trophic structure of herbivore-parasitoid networks and the persistence of natural pest control on farms. Instead, the presence of effective parasitoid species was a determining factor (see the 'functional identity hypothesis' above).

\subsection{Other indicators of resilience}

Early-warning signals

Considerable effort has been spent in recent years on understanding and identifying possible 'early-warning signals' of an (eco)system's proximity to critical thresholds or tipping points, which if passed may lead to shifts in the system's structure, function, identity, and feedbacks (Scheffer et al., 2015). Such signals have been termed indicators of Critical Slowing Down (Dakos et al., 2015), because ecosystems approaching their tipping points have been found to recover more slowly from disturbance (thus being less ecologically resilient) than ecosystems that are far from their tipping points (Dakos et al., 2015; Scheffer et al., 2015). Indicators of an ecosystem or ecosystem function

472 slowing down before transitioning to a contrasting state include decreasing recovery rates after 473 disturbance (reflecting engineering resilience; Scheffer et al., 2009), increasing spatial or temporal 

Brock, 2006). predict the proximity of ecosystems and functions to tipping points, both theoretically (Bailey, 2010; Dakos et al., 2011) and empirically (Dai et al., 2013; Veraart et al., 2012), in studies from semi-arid grasslands (Bestelmeyer et al., 2013) to experimental microcosms (Veraart et al., 2012). In contrast, rising spatial or temporal autocorrelation and variance sometimes, but not always predict the onset of tipping points (Carpenter and Brock, 2011; Dakos et al., 2012). In some systems these indicators may even decrease before critical transitions, causingseveral authors to emphasize the need for caution and good system knowledge before interpreting them (Dakos et al., 2015; Génin et al., 2018). In addition, most of the work evaluating the performance of early-warning indicators has not been performed in agroecosystems, where inherent variability and heterogeneity of cropping patterns may strongly impact the meaning and applicability of such signals (Vandermeer, 2011). Instead, work has focussed on natural ecosystems such as lakes and semi-arid grasslands (Dakos et al. 2010). Recently, Génin et al. (2018) examined for the first time the behaviour of early-warning indicators in spatially structured ecosystems subject to spatially heterogeneous stress, as is the case in agroecosystems (mussel beds, dryland vegetation and forest). They show that heterogeneous stress can confound expected trends of the indicators based on patterns of critical slowing down and spatial patch structure (Génin et al., 2018). Thus, it remains to be determined to what extent signals of critical slowing down can be applied to infer the resilience of agroecosystem communities and functions across disturbance gradients (Dakos et al., 2015; Dakos, 2018).

Self-regulation, exposure to disturbance and local coupling 
and interactions). These indicators are identified as particularly relevant in agroecosystems (Cabell

500

501

502

503

504

505

506

507

508

509

510

511

512

513

514

515

516

517

518

519

520

521

522

523 and Oelofse, 2012). But to date, tests of their association with the persistence, engineering or ecological resilience of biodiversity-driven functions are scarce. Instead, studies have mainly examined the impact of these indicators on the resilience of the agroecosystem as a holistic socialecological system (sensu e.g. Folke et al. 2010) without assessing the resilience of specific functions (Cabell and Oelofse, 2012; Peterson et al., 2018). In theory, self-regulation and internal feedbacks such as density-dependent functioning are likely to be positively related to function persistence and ecological integrity (the ability of an ecosystem to support and maintain an adaptive biological system with the full range of elements and processes expected in the natural habitat of a region; Mora, 2017). In a specific example, self-regulation by ecosystem engineers (termites, earthworms, ants) of pre-Columbian 'raised-field' cultivation systems may have contributed to the long-term persistence of soil services and fertility by contributing to e.g. nutrient cycling, soil structure improvement and organic matter content(McKey et al., 2010). Mild exposure to disturbance that does not push function providers beyond survival thresholds may foster their ability to adapt and recover from further disturbances through e.g. phenotypic plasticity (Oliver et al., 2015a), which may increase their resilience to other drivers of change in the future (Kühsel and Blüthgen, 2015). Finally, locally coupled functions that rely on the biodiversity of locally available and/or native organisms, such as pollination of traditional crops by native pollinators (Partap and Ya, 2012) or local availability of parasitoids of pests, are likely to increase the persistence, engineering and ecological resilience of functions by preventing reliance on a small number of imported species with low local adaptation or with the potential for invasiveness and competition.

\section{Section 3: Resilience of agroecosystem functions to environmental change}

In the previous section, we outlined existing indicators with the potential to assess the resilience of functioning in agroecosystems, and their degree of validation by theoretical and 
empirical studies. Here, we examine what lessons can be learned from the use of such indicators, as well as from measures of function resilience itself. Specifically, we ask: (i) how resilient are agroecosystem functions to disturbances related to environmental change? and (ii) how is function resilience affected by disturbances related to environmental change? To assess these questions we focus on three biodiversity-driven, regulatory ecosystem services: (1) biological pest control, (2) disease suppression in soils, and (3) crop pollination.

\subsection{Biological pest control}

The general term biological pest control encompasses both the effect of naturally occurring enemies and antagonists, and of introduced or augmented biological control agents that reduce populations of different pestiferous organisms (Eilenberg et al., 2001). Here we focus on naturally occurring predators, parasitoids and pathogens of arthropod pests (biological control of plant diseases is discussed in Section 3.2). Biological control can help to keep damaging effects of pest species on crops below economically significant thresholds and thus reduce the need for direct pest control measures such as insecticide application. A key element of the effectiveness of biological control of agricultural pests is the presence and maintenance of a high abundance and diversity of natural enemies (Jonsson et al., 2017; Landis et al., 2000). However, antagonistic interactions among enemies can influence their potential to effectively control pests. In addition, the fact that predation is often density dependent means that measures of enemy abundance and diversity are often insufficient to assess the potential of a community to provide effective biological control. As a result, biological control potential is typically assessed using predator exclusion cages with standardized densities of (pest) prey, or by estimating attack rates on sentinel prey (Birkhofer et al., 2017; Lövei and Ferrante, 2017).

control itself are of a snap-shot character, and are thus not able to tease apart the temporal responses of biological control to disturbances. These studies mainly examine how persistent 
biological control services are under varying strengths and types of environmental disturbance. Indirect evidence that disturbances affect engineering and ecological resilience of biological control thus far mainly stems from studies of biodiversity-based resilience indicators. Based on that, we review the consequences of disturbances for the persistence of this service and for indicators of its resilience based on characteristics of natural enemy communities separately.

Land use intensity at landscape and local scales biological pest control have been extensively studied both at field and landscape scales, sometimes also considering interactive effects between scales. When agricultural intensification is realised at the landscape level, a significant loss and/or fragmentation of natural and semi-natural habitat is often the consequence. A number of studies have explored the persistence of biological control in relation to land use intensity gradients at the landscape level. Rusch et al. (2016) re-analysed ten datasets assessing aphid control with predator exclusion cages, and found that there was a consistent reduction in pest control services with landscape simplification ( $46 \%$ lower pest control in landscapes dominated by cultivated arable land). However, in a recent global re-analysis of exclusion cage studies no consistent effect of landscape simplification was found across studies, with approximately equal proportions of studies showing positive, negative or no effects of landscape simplification (Karp et al., 2018). Thies et al. (2011) studied biological control of aphids in cereal crops across Europe and found that pest control by natural enemies was reduced by landscape simplification in some regions but not in others. Thus, it appears that biological control in certain crop-pest-natural enemy systems in specific regions is more persistent to disturbances associated with landscape effects of modern agriculture than in others. diversity and abundance of natural enemies. For instance, a reduction in suitable habitat in agricultural landscapes had negative effects on parasitoid communities and parasitism rates (e.g. 
574 Kruess and Tscharntke, 1994, 2000; Menalled et al., 2003; Thies and Tscharntke, 1999). Habitat loss

575 or degradation can also lead to a reduction in the diversity of birds and bats and limit their potential

576 for pest control (e.g. Faria et al., 2006; Kalda et al., 2015; Perfecto et al., 2004; Redlich et al., 2018;

577 Tscharntke et al., 2008b). Furthermore, this factor has been linked to a reduction in the biodiversity

578 of ground-dwelling arthropods with negative effects on the pest control services they provide

579 (Nurdiansyah et al., 2016; Rusch et al., 2013, 2016; Weibull et al., 2003; Woodcock et al., 2010).

Response diversity of natural enemies to land use intensity has been studied for both

functional and taxonomic groups. For example, Martin et al. (2016) found that the response of

natural enemies to landscape simplification differed between taxa, with five out of seven broad natural enemy taxa being negatively affected by a simplified landscape configuration, but only carabids being negatively affected by reduced amounts of semi-natural habitat in the landscape. Typically, individual species and functional groups of species contribute differently to biological control services and if dominating key species or groups are particularly sensitive to disturbance this could have strong implications for resilience (see Table 1). Martin et al. (2013) found that flying predators were the most functionally important group for biological control of lepidopteran pests on cabbage in South Korea, but its effects on biological control were also the most sensitive to landscape simplification. Maas et al. (2015) studied predation in Indonesian cacao plantations and found that certain insectivorous birds with key importance for biological control were particularly sensitive to the distance to natural forest.

At local scales, a range of studies have explored how species diversity and biological control are affected by organic farming by comparing fields or farms under organic and conventional (intensive) management. Tuck et al. (2014) reviewed such studies and showed that the diversity of predators and several other functional groups was higher on farms under organic management. Östman et al. (2003) used predator exclusion cages combined with modelling to show that biological control was about twice as high in organic compared to conventional barley fields in Sweden. 
Together, these studies indicate that 1) biocontrol is not persistent to conventional management and 2) if maintained, conventional management should lead to decreased resilience of biocontrol to further disturbances.

Other studies have focused on the effects of individual disturbances. In a large European study, insecticide application was found to consistently reduce both predator diversity and biological control services (whereas fertilization levels had no effect) (Geiger et al., 2010). Insecticides often increase mortality of the natural enemies, but there is also evidence that it may modify natural enemy behaviour. For example, Stapel et al. (2000) found that insecticide application in cotton fields temporarily affected the foraging ability of a parasitoid wasp, thus reducing its ability to successfully control pest species for up to 18 days. Insecticides are known to affect species of natural enemies differently (Pisa et al., 2015), depending on their physiology and exposure to insecticide applications. Thus, it is clear that there is a response diversity for natural enemies in relation to insecticides, as long as enemy communities include species or individuals with variable responses. Biological pest control provided by such communities can be expected to be resilient against insecticide application. However, the available evidence (Geiger et al., 2010; Östman et al., 2003) suggests that in conventional European crops, this mechanism is currently either lacking or insufficient to maintain persistent biological control under insecticide use. In addition, where a degree of control is maintained, lower diversity of enemy communities on conventional farms and under insecticide application is likely to imply lower resilience of biological control to further disturbances. Herbicides rarely have direct lethal effects on arthropods, but application of certain types of herbicides such as glyphosates have been found to modify arthropod (predator) behaviour (Korenko et al., 2016). The main effect of herbicide application is, however, in most cases indirect, acting via reduced habitat heterogeneity and reduced availability of alternative food sources (Nyffeler et al., 1994). Accordingly, it has been shown that predator abundance and diversity are reduced both when herbicides are applied (Asteraki et al., 1992) and when weeds are manually removed (Diehl et al., 2012). In a recent study, Staudacher et al. (2018) found that herbicide application induced a rapid 
change in predator-prey network structure, with increased levels of prey specialization across generalist predator species, probably as a consequence of enhanced competition among predators (Staudacher et al. 2018). Thus without herbicide application, niche-overlap was larger among predators suggesting that the level of functional redundancy was higher. et al. (2016) showed that conventional tillage including ploughing had negative effects on both predator abundances and their potential to control pests, but only in simplified landscapes. This provides evidence that complex landscapes can provide cross-scale community resilience making biological control persistent to local field-level disturbances. Thorbek and Bilde (2004) studied the effects of several agricultural management measures related to disturbance (ploughing, noninversion tillage, superficial soil loosening, mechanical weed control and grass cutting) on abundances of ground dwelling predators. All measures were found to reduce predator abundances, and the predators seemed to aggregate in less disturbed areas. community-wide effects of land use intensification on biological control services. In particular, habitat degradation has been demonstrated to change the complexity of interaction networks and to alter interaction strengths between providers of pest control services and their prey. Laliberté and Tylianakis (2010), for example, have demonstrated that deforestation in tropical agroforestry systems leads to a spatio-temporal simplification of parasitoid-host networks, resulting in a homogenized interaction composition, and thus reduced potential resilience across rice and pasture sites in comparison to forested habitats. Gagic et al. (2012) report overall lower parasitism rates despite a higher complexity of the food web structure in an aphid-parasitoid-hyperparasitoid system in areas of high agricultural intensification. 
variability of parasitism rates when parasitoid diversity was high, which happened in this case in highly modified habitats. Similarly, MacFadyen et al. (2011) found lower variability of parasitism rates when parasitoid species richness was high, but in this study this occurred in organic (less disturbed) farms as opposed to conventional ones. In a unique attempt to test ecological resilience, MacFadyen et al. (2011) also simulated parasitoid removal from food-webs to assess the robustness of pest control under scenarios of extinction, but did not find any difference between farming systems. Rusch et al. (2013) studied within field variability in biological control using exclusion cages and found that the within-field spatial variabilityin biological pest control services decreasedwith crop rotation intensity in the landscape, although variability in parasitism rates increased. with land use at field and landscape levels affect various biodiversity-based resilience indicators, and a growing number also explore effects on biological control services themselves, using exclusion cages or sentinel prey. Applying space-for-time substitution (De Palma et al., 2018), these studies show that persistence of biological control in the face of disturbance caused by land use intensity varies between crop-pest systems and regions. Also, the effects appear to depend on the actual disturbance, with insecticide application for example showing consistent negative effects on biological control, whereas landscape effects seem to vary more. However, the reasons for different levels of persistence are rarely known - even if they seem to correlate in several cases with levels of natural enemy diversity. The great majority of available studies are of short-term snapshot character and do not examine temporal aspects of resilience, such as the ability of biological control to recover or persist over the long term. Instead, a few studies have considered changes in spatial or temporal variability in relation to disturbance. To date, effects of land use intensity on engineering resilience are few and ecological resilience has almost not been studied at all (but see MacFadyen et al. 2011). 
more limited than those investigating resilience to land use intensity. In general, models predict that pest problems will increase with climate change in large parts of the world, except in the lowland tropics (Deutsch et al., 2018; e.g. Diffenbaugh et al., 2008; Maiorano et al., 2014). A recent global study of maize, rice and wheat, for example, predicted that crop losses due to pests would increase by $10-25 \%$ globally, with the largest increases taking place in temperate areas where current yield levels are highest (Deutsch et al., 2018). However, such models are usually based on pest biology (e.g. metabolic rates and population growth; Deutsch et al., 2018), and ignore the potential impact of natural enemies, which could buffer against or enhance the predicted changes in crop losses depending on how enemies are affected by climate change. (Hillebrand, 2004) and a recent global assessment of predation rates showed that predation rates by arthropods increase towards the equator and at lower elevations (Roslin et al., 2017). This suggests that predators are generally both more diverse and have a stronger top-down impact on herbivore populations at higher temperatures. It remains unclear however, whether predators will be able to track the changes in climate to maintain these patterns under future conditions. Indeed, it has been predicted that biological control may be reduced under climate change in specific systems. For example, a modelling study on host-parasitoid food webs predicted that increasing ambient temperature could lead to a reduction in biocontrol services in systems where tolerance for higher temperatures is lower in parasitoids than their hosts (Furlong and Zalucki, 2017). predator communities and the implications for resilience of biological control. In a unique experimental study, Drieu and Rusch (2017) found that diverse predator communities shifted from being redundant to being complementary in their effects on leaf hopper pests on grape wines when 
evidence for response diversity of predators in relation to temperature. Thus such diverse predator communities are likely to provide resilient biological control under climate change.

Barton and Ives (2014) found that water stress in alfalfa led to reduced growth rates of pea aphids, which led to fewer ladybeetle predators and ultimately reduced predation rates on spotted aphids and a release of this aphid species from top-down control. Effects on biological control may become even more difficult to predict if drought is combined with elevated temperatures. Using a combination of field observations and laboratory mesocosm studies of cabbage aphids and their parasitoids, Romo and Tylianakis (2013) showed that the parasitoids had a better ability to control aphids under increased temperatures and drought when studied separately, but that the results were reversed when the two disturbances were combined. However, the role of biodiversity in providing resilience against drought has not been explicitly studied. predator diversity and resilience of biological control services does not allow reliable predictions about their resilience in future climate scenarios. In addition, the potential to generalize results of individual studies to form such predictions could be limited, because responses are likely to vary with respect to direct and indirect impacts of climate change on both enemies and pests as well as their host plants, and because interactive effects of different aspects of climate change and other disturbances may be common (Sasaki et al. 2015; Thomson et al., 2010).

\subsection{Plant disease suppression in soil}

Soil-borne plant diseases are important threats to agricultural crops, resulting in severe yield losses. These diseases are often difficult to control by conventional strategies such as chemical disease control or the use of resistant cultivars (Weller et al 2002). Therefore, protection and 
management of naturally occurring disease suppression in soils constitute an interesting possibility

724

725

726 for sustainable disease control in agricultural crops. The ability to suppress diseases is a quality of the soil that can be enhanced or destroyed by environmental factors connected to global change, including cultural practices and other disturbances (Larkin 2015).

All soils have some capacity to suppress soil-borne plant pathogens and the diseases they cause. Soils with strong disease suppression were described early on as suppressive soils, in contrast to conducive soils, where disease occurs readily (Baker and Cook 1974). However, the ability to suppress diseases is better described as a continuum from strong disease suppression to very limited suppression (Alabouvette et al., 2006b). The mechanisms of importance for suppression vary with the ecological strategy of the pathogen, and the combination of pathogen and host plant (the 'pathosystem'; Termorshuizen and Jeger, 2008). Thereby, there is also variation in the ability of the suppression to withstand disturbances. Typically, the mechanisms behind the suppression are not fully understood. Suppression can be due to biotic or abiotic factors or the combination of both, and involve both suppression of pathogen growth and of disease development (Kinkel et al., 2011). Cases where the suggested mechanisms are purely due to abiotic factors will not be covered here.

In contrast to above-ground pest control, the available literature on disease suppression in soil mainly focuses on the scale of plots to fields, though some studies have investigated interactions of general soil functions (e.g. as approximated by soil organic matter content) with landscape-scale simplification (Gagic et al., 2017). Climatic disturbances and change may theoretically have strong impacts on disease suppression in soil and its persistence (Stres et al., 2010). However, few studies have investigated these effects considering realistic ranges of temperature or precipitation change. Typically, disease suppression in soil is assessed by performing bioassays where an isolate of the pathogen is inoculated into the soil, and a susceptible plant is grown under temperature and humidity favourable for disease development. Specific mechanisms or processes of importance for suppression are also commonly studied on nutrient media or other laboratory conditions, for 
example restriction of fungal spore germination (fungistasis) or inhibition of microbial growth (microbiostasis; (Ho and Ko, 1982; Lockwood, 1977). to form the suppressive ability of a specific soil (Weller et al 2002). General suppression is related to unspecific competition for niche space bythe total microbial biomass in soil and its activity (Termorshuizen et al., 2006). This type of suppression is widespread, occurs more or less in all nonsterile soils, and is often enhanced by the addition of organic material. Especially in the case of competition sensitive pathogens, this type of suppression can be of great importance, for example in the suppression of corky root of tomato, caused by the fungus Pyrenochaeta lycopersici (Hasna et al., 2007). As general soil suppression is caused by the total activity of the microbial biomass rather than specific species, it is not particularly sensitive to disturbances as long as the microbial activity is maintained or increased. One example of compromised general suppression can be seen after the drastic disturbance caused by sterilisation of greenhouse soils in tomato production. After soil sterilisation, Fusarium crown and root rot caused by Fusarium oxysporum f.sp. radicis-lycopersici developed readily in an environment with few competitors (Rowe, 1978). However, after sterilisation, all soil organisms with more or less specific interaction with the pathogen are similarly killed. Thus, deleterious effects of soil sterilization on persistence of soil disease suppression can also be due to loss of organisms with more specific interactions (specific suppression). Specific suppression is, in contrast to general suppression, suggested to be due to the effect of one or a few groups (species or isolates) of organisms that are antagonists to the pathogen or active in disease suppression in other ways (Weller et al., 2002). In some cases, specific suppression can even be due to the production of specific antagonistic substances such as antibiotics (Weller et al., 2002). The effect of a disturbance on specific suppression depends completely on how sensitive the important organism(s) are to the disturbance and how well they can recover from it. In several of 
the best studied examples of specific suppression, the organisms of importance have been isolated and transferred to other soils, resulting in disease suppression also in these soils (Weller et al., 2002). This transferability has been used to prove the role of a specific isolate in disease suppression, but requires that the organism that is isolated is competitive enough to colonize the soil to which it is transferred.

\section{Field-scale disturbances: agricultural management and crop rotation}

For several soil-borne plant pathogens, soils with strong disease suppression have been identified. In these soils, the disease development is limited even in presence of pathogen inoculum and under environmental conditions favourable for disease development. Although the important mechanisms occurring in theses soils are not fully understood and are known to vary with the pathosystem, the suppressive activity is suggested to be complex in its nature, and caused by a combination of general and specific suppression (Weller et al 2002; Schlatter et al 2017). In certain cases, the disease suppression is long-standing, with little variation over years and not drastically changed depending on the crop rotation or cultural practices used. One example of such longstanding suppression is found in Fusarium wilt-suppressive soils of Châteaurenard in France, which has been attributed to the combined activity of certain non-pathogenic strains of $F$. oxysporum and the bacterium Pseudomonas fluorescence (Siegel-Hertz et al., 2018; Trivedi et al., 2017). The reason for persistence of the disease suppressing activity of this soil is not well understood. It has been suggested that the fact that the suppression is long-lasting serves as a proof for direct or indirect influence of physicochemical soil characteristics. The importance of environmental factors in influencing the structure and function of soil microbial communities is supported by Griffiths and Philippot (2013), Banning and Murphy (2008) and Orwin and Wardle (2006). According to these authors, the persistence in soil functioning over time, despite varying levels of disturbance, is a result of interactions between the microbial community structure and environmental factors such as soil type or nutrient availability. 

organic material, specific crop rotations or by crop monoculture (Raaijmakers et al 2009). For example, suppression of Fusarium wilt can be induced by continuous cropping of partially resistant cultivars. This induced suppression is suggested to be largely caused by non-pathogenic isolates of Fusarium oxysporum, and to be mainly due to induced pathogen resistance in the host plants. This is in contrast to the long-standing suppression in Châteaurenard described above, which also involves suppression of the pathogen's saprotrophic growth and spore germination (Larkin, 1996; Weller et al., 2002). Another example of monoculture-induced suppressiveness is take-all decline - a reduction of take-all of wheat (caused by Gaeumannomyces graminis var. tritici) after continuous cropping of susceptible cultivars and at least one severe outbreak of take-all. As a response to the build-up of pathogenic populations, a range of antagonistic microorganisms accumulate in the soil, resulting in strong disease suppression. This phenomenon has been described to occur worldwide, with some variation in its extent and speed of development. However, it is not long-standing and is lost when the monoculture is broken (Weller et al., 2002). In these examples, intensification of cropping practices illustrated by increased use of monocultures is thus shown to have a positive impact on the persistence of disease suppression in soil. This is in stark contrast to the effects of this driver generally observed on e.g. above-ground pest control, and to findings that species-rich plant communities can lead to suppression of plant pathogens (Mommer et al., 2018) or increase the disease suppressive potential in soil (Latz et al., 2016)

Field to microcosm scale: incorporation of organic material Soil suppressiveness can be induced by addition of various types of organic material to the soil, or by leaving crop residues in the field to promote decomposers living on the residues (Raaijmakers et al., 2009). Addition and incorporation of organic material can be regarded as a type of disturbance of the soil system, changing the habitat for organisms living there, although in this case, the purpose is to increase the activity of beneficial organisms suppressing plant diseases. As 
such, this practice represents the inverse trend to depletions of soil organic matter characteristic of current agricultural intensification. The use of composted plant material to induce soil suppressiveness has been studied extensively and found to have the potential to suppress various types of plant diseases, through competition-based suppression as well as other mechanisms importance. Effects of soil treatments also depend on site-specific soil characteristics. PérezPiqueres et al. (2006) studied the effect of four composts in two soils with differences in biological and physicochemical characteristics. In both soils, all four composts caused changes in bacterial and fungal community structures, and effects on community-level physiological profiles and suppression of damping of pine (Pinus nigra), caused by Rhizoctonia solani, varied depending on the combination of compost and soil. other crops containing glucosinolates, a strategy called biofumigation. When such plant material is incorporated into the soil, the glucosinolates are hydrolysed into a range of products with a broad biocidal activity. This results both in direct reduction of microbial populations, including pathogens, and in secondary effects when saprotrophic organisms use the plant material as a food source. The relative importance of these two effects is debated, and depends on the chemical properties of the

841 plant material and site-specific soil characteristics. The suppression has been correlated with both 842 reductions in pathogen populations (Smolinska et al., 2003), with increases in microbial biomass or 843 activity (Yulianti et al., 2007), with changes in the microbial community structure (Wang et al., 2014) 844 or with increases in specific pathogen antagonistic populations (Mazzola et al., 2007; Weerakoon et al., 2012). 
suppress diseases depend on the type and amount of material applied (Yohalem and Passey, 2011). In biofumigation treatments, the toxic products do not have any known long-lasting effect. Their main activity lasts from hours up to a few days (Matthiessen and Kirkegaard, 2006). Effects of the organic material itself last longer, as well as secondary effects from changes in the abundance and structure of communities. Many responses of the microbial community are seen directly after a biofumigation treatment, after which the community slowly returns to its initial biomass and community structure. Especially the bacterial community seems to be influenced by biofumigation treatments, but it appears to return to initial structure and biomass within a few months. In contrast, fungal communities are more resistant and take a longer time to return to initial structures (Friberg et al., 2009; Mocali et al., 2015; Wei et al., 2016). There is limited information about how the duration of responses in microbial communities relates to the suppression of diseases. In some cases, the biofumigation effect on disease suppression lasted longer than changes in microbial community structure were detected (Friberg et al., 2009). This indicates that the engineering resilience of the community to biofumigation may be higher than the resilience of functioning itself. At least in part, such lack of correlation in changes in population structures compared to the suppression could be due to differences in the sensitivity of methods used to characterize communities and assess suppressiveness.

To conclude, there are examples where disease suppression in soil is persistent to disturbances connected to cropping practices occurring over both long and short time scales. These include examples of long-lasting specific disease suppression resilient to variation in cropping practices and crops over time, but also examples where the suppression is highly dependent on specific practices and collapses if these practices change. Several studies have focused on the beneficial effects on suppressiveness obtained by adding or preserving organic material in the soil. Based on this, agricultural intensification leading to a depletion in soil organic matter should be considered as one of the most problematic consequences of global environmental changes. To date, resilience of disease suppression in soil has been addressed in terms of direct measures of function 
persistence and engineering resilience, including long term studies. In contrast, effects of disturbances on resilience indicators, including measures of community structure for disease suppressing organisms, are less frequently studied in this framework. Mechanisms of disease suppression are often complex and vary between sites and pathosystems. Through a better understanding of the processes and organisms of importance, agricultural practices and measures could be adjusted to, at least partly, counteract negative effects of global change on plant health.

\subsection{Crop pollination}

The evidence for a decline of bees (and more generally pollinators, Biesmeijer et al. 2006) raises alarm for the resilience of their supporting pollination services to pollinator-dependent crops (Potts et al. 2016). Indeed, less diverse pollinator communities may provide ecosystem services that are less resilient to disturbance over space or time (e.g. Rader et al. 2013; see discussion in previous section). Bees are the most important group of pollinators in temperate climates (Ollerton et al. 2011), and provide critical pollination services for wild plant communities and agricultural productivity (Potts et al. 2016). Nearly $90 \%$ of the world's flowering plant species (angiosperms) are pollinated by animal mediation (Ollerton et al. 2011), including ca. $70 \%$ of world crops (Klein et al. 2007). However, bees as well as pollinators in general are currently declining worldwide (Cameron et al. 2011, Goulson et al. 2015, Potts et al. 2010, 2016), and plant-pollinator networks are disturbed (Biesmeijer et al. 2006, Fitter and Fitter 2002). For instance, during the last decades, the diversity of bees observed in Great Britain and the Netherlands has decreased by more than half, in parallel with the decrease of the diversity of plants (Biesmeijer et al. 2006). Crop pollination is therefore commonly cited as an example of an endangered ecosystem service and several studies have analysed the risk of pollination deficits, and their relations to global environmental changes that affect pollinator biodiversity.

\section{Assessing crop pollination service}



metrics. The simple measure of the abundance and diversity of flying bees captured inside the crop has been used as a proxy of the visitation rate of flowers (e.g. Carvell et al. 2007, Le Féon et al. 2010, 2013). Pan traps are widely used for this purpose (but also transects with net catch). When placed in the crops, pan traps mimic flowers and collect visiting pollinators. This estimate is very approximate and potentially not related to actual pollination success, because collected bees may be either flower visitors or just crossing the field without visiting flowers. Moreover, no estimate of pollen deposition is available through this method. Other studies use the direct measure of the number of pollinator visits per flower as a proxy of pollination service (e.g. Bartomeus et al. 2014). This method allows to estimate the abundance and diversity of flower visitors. Nevertheless, the relationship between bee visit and pollen deposition is missing (i.e. the transport of pollen from the anthers

910 [male organ] to the stigma [female organ]). This prevents any robust estimation of the pollination service itself as, for instance, some bees are known to "rob" the nectar of plants without any process of pollen deposition (Saez et al. 2017). The most rigorous approach to estimate the pollination service of bees is to measure pollen deposition per bee visit. Some studies have counted the number of pollen grains deposited by bees on the plant stigma, after excluding the relative contributions of wind and self-pollination through exclosures (Kremen et al. 2002, Cariveau et al. 2013). In parallel, bee visits were also surveyed (i.e. the abundance and diversity of bee visitors was recorded). This rigorous estimate of pollination service is time-consuming (microscopic counting of pollen grains deposited on the stigma) and complex to replicate, which is why few studies have applied this method. A more frequently used alternative is counting the number of seeds produced per flower or

920 plant (i.e. seed set), following the same protocol of exclusion (e.g. Holzschuh et al. 2012, Garratt et al. 2014, Porcel et al. 2018). 

on the resilience of pollination services and its indicators in agroecosystems. We focus especially on bees due to their critical importance as pollinators, but studies with comparable metrics and patterns have considered other pollinator groups (e.g. Rader et al. 2016). major cause in the decline of bee-driven pollination services in agroecosystems (Goulson et al. 2015, Potts et al. 2010, 2016). At the landscape scale, the loss and degradation of semi-natural habitats has reduced the amount and diversity of floral resources (Goulson et al. 2008, Williams \& Osborne 2009) and the availability of nesting sites for pollinators (Steffan-Dewenter \& Schiele 2008), resulting in a general decline in bee abundance and diversity in agricultural areas. Compelling evidence of positive effects of the proximity and amount of natural (or semi-natural) habitats on the abundance and diversity of bee visits in crops is available from several studies and syntheses (e.g. Kremen et al. 2002, Ricketts et al. 2008, Cariveau et al. 2013, Kennedy et al. 2013). These studies confirm the benefits of natural habitat for bee diversity in pollinator-dependent crops. However, the associated improvement of pollination service is undemonstrated. While some studies show an increase in pollen deposition with proximity to natural habitat (Kremen et al. 2002, Cariveau et al. 2013), others show no effect on fruit and seed set (Ricketts et al. 2008), thus implying persistence of pollination services under landscape simplification and habitat loss. Finally, some studies examined the engineering resilience (recovery) of pollinator communities after restoration or planting of seminatural habitats, i.e. under a reversal of the trends in agricultural landscape simplification. These studies focus on bee abundance and diversity in crops (e.g. using pan traps) and not on pollination itself. They provide evidence of positive effects of wildflower planting and restoration of native plant hedgerows on the diversity of pollinator communities (e.g. Williams et al. 2015, Kremen and M'Gonigle 2015), suggesting beneficial effects of these measures on the resilience of pollination to future environmental disturbance. 

insecticides induce sub-lethal effects on bee behaviour and survival (Henry et al. 2012). Indirectly, e.g. herbicides decrease the availability of floral resources and fertilizers decrease the diversity of infield plants (Gabriel and Tscharntke 2007, Holzschuh et al. 2007, Goulson et al. 2015). Recently, evidence has been found for negative effects of exposure to e.g. neonicotinoid insecticides on wild bee density and flower visits (Rundlöf et al. 2015). In a uniquely long-term dataset monitoring bees in Great Britain over 18 years, these deleterious effects have been shown to extend to whole communities of bee pollinators, affecting both the persistence and likelihood of extinction of many species (Woodcock et al., 2016). In contrast, organic farming (without insecticide exposure) has been shown to increase the diversity and abundance of native bees in agroecosystems compared to conventional management (Kremen et al. 2002). However, expected stronger provision of associated pollination services (fruit set or pollen deposition) in organic management, which would imply low persistence of pollination under insecticide use, is controversial (see Kremen et al. 2002, Porcel et al. 2018).

Supplementation of managed pollinators, and other disturbances (Biesmeijer et al. 2006) until a tipping point of pollination resilience is reached that could be viewed as either (1) the complete extinction of wild bees, or (2) the absence of trait-matching between local bees and crop flowers (e.g. Garibaldi et al. 2015, Bartomeus et al. 2016). The first (extreme) scenario occurs in some parts of Asia. In recent years, farmers have been forced to hand-pollinate apple trees, carrying pots of pollen and paintbrushes with which to individually pollinate every flower, after the extinction of local pollinators due to habitat degradation (Partap and Ya, 2012). The second scenario could occur with the current decline in bee diversity (see below; Biesmeijer et al. 2006, Potts et al. 2010, 2016). Supplementation of managed generalist pollinators is now common in 
973 2017). For this purpose, the western honey bee (Apis mellifera L.) is the species that is most widely used across the world, although recent studies proposed management of other species (reviewed in 975 Garibaldi et al. 2017, Isaacs et al. 2017, Pitts-Singer et al. 2018). The currently most common management practice to reduce potential pollination deficits in pollinator-dependent crops consists of increasing the stock rate of managed honey bee colonies per unit area (Isaacs et al. 2017). decreasing their flower visitation (by competition), reproductive success, abundance, and diversity (Elbgami et al. 2014, Goulson et al. 2009, Hudewenz and Klein 2013, Geslin et al. 2017, Geldmann and González-Varo 2018). Thus, artificial supplementation of pollinators can have detrimental effects similar to the introduction of invasive species. In this way, some managed pollinators that have been introduced for crop pollination out of their native range, are currently invasive. In particular, the introduction of Bombus terrestris for the pollination of tomato in Chile has led to a large scale invasion throughout Latin America, and the collapse of native bumble bees through competition for resources (Morales et al. 2013). Thus, supplementation of managed pollinators can affect the resilience of the pollination service in agroecosystems. In addition, other threats may affect pollination service resilience such as the spread of invasive parasites and pathogens of pollinators, cross-transmission between managed populations and wild species, and impacts of climatic disturbances and change on shifts in the range of native pollinator populations (reviewed in Potts et al. 2010, 2016). However, to our knowledge, none of these studies have investigated these effects on the resilience of pollination services or associated indicators.

Resilience of crop pollination to disturbance: major knowledge gaps 
998

(recovery) of pollinator communities. In addition, the majority of studies focus on the resilience indicators of species richness or diversity of bees, but few explore effects of disturbances on other indicators involving functional traits. Based on available studies, the resilience of pollination services in agroecosystems is likely to be threatened by multiple disturbances including habitat loss, pesticide use, supplementation of managed pollinators and climate change (Potts et al. 2016). Persistence of these services may be supported by organic practices and the restoration of semi-natural habitats, but little is known to date about long-term effects of other environmental measures such as flower planting. Furthermore, a more realistic context of trait-matching of mutualistic interactions, as already described in natural ecosystems (Fontaine et al. 2006, Thébault and Fontaine 2010) currently needs to be considered.

Trait-matching is the process by which pollinators have coevolved specialized mutualisms with flowering plants. It is characterized for instance by pollinators with long tongues mainly visiting plants with deep corolla, suggesting a strong match between flower and pollinator morphology at the individual scale (Garibaldi et al. 2015, Bartomeus et al. 2016). Due to the spatiotemporal heterogeneity of cropping patterns, extension of methods developed outside agroecosystems to assess ecological resilience of pollination in agroecosystems may be contingent on the consideration of trait-matching between pollinators and crops. Indeed, in a first step considering the provision (not the resilience) of pollination services, trait-matching has been shown to better predict success of crop fruit set than trait diversity (Garibaldi et al. 2015).

However, to our knowledge, no studies have analysed the effect of environmental disturbances on the persistence or recovery of trait-matching in agroecosystems. We hypothesize that such approaches would be robust measures of the resilience of pollination services. Moreover, to our knowledge no study has considered the implications of the planting of exotic crops for the resilience of pollination (or other services) in agroecosystems. Indeed, movements of wild bees from local (semi) natural habitats into crop fields are often expected to benefit the provision and 
persistence of pollination services in crops. However, this expectation does not consider the fact that most pollinator-dependent crops are exotic in the system. Pollinator-dependent crops are indeed frequently established whose flower traits do not match the traits of the local (native) bee community. Thus, (1) no local bee will be able to pollinate the crop, (2) the crop will reduce the availability of nesting and feeding semi-natural habitats for local bees, (3) farmers will need to practice supplementation of managed generalist pollinators (or "human pollinators", Partap and Ya 2012), that can spillover into semi-natural habitat after the flowering period of the crop and therefore compete with native wild bees, reducing their fitness and affecting the resilience of the pollination service through a number of mechanisms (Table 1). This drastic scenario does indeed apply in the case of the use of plants with deep corollas (such as perennial leguminous herbs) that often require trait-matching interactions with very long-tongued bees, which are currently endangered (Cameron et al. 2011). Overlooking the trait-matching mutualistic interactions of pollination services should annul efforts of currently applied pollinator-friendly schemes (e.g. reducing pesticide exposures, increasing natural nesting and flowering habitats). Thus, we hypothesize that cultivating crop plants with trait-matching to local wild bee populations would enhance the resilience of pollination services against present and future environmental disturbances.

\section{Section 4: Operationalizing resilience: a critique and steps ahead}

In the previous section, we reviewed to what extent measures of resilience to environmental disturbances have been operationalized to date for three key biodiversity-driven services in agroecosystems. We conclude that in contrast to certain other functions or services (e.g. biomass production, Isbell et al., 2015) and certain other ecosystems (e.g. coral reefs; Nash et al., 2016), measures of resilience for these functions lag behind in their ability to uncover mechanisms and to predict response trajectories to various types of disturbances. Indeed, for the functions considered, 
only very few studies have investigated even the more 'accessible' measures of engineering resilience (Ingrisch and Bahn, 2018) by testing recovery rates after disturbance. More complex measures of ecological resilience remain, for now, essentially uncharted territory (but see Macfadyen et al. 2009, 2011), despite developing approaches outside agroecosystems that may represent important stepping stones (e.g. for pollinator networks; Jiang et al., 2018).

Instead, many studies measuring the functions of interest focus on (1) the persistence of functions under disturbance or (2) on indicators (particularly biodiversity-based) of the resilience of functions. Generally, these studies are not framed to examine a component of resilience.

(1) In the case of measures of function persistence, studies on pollination and biological pest control most often use snap-shot measures that inform on the state of the function after disturbance. However, they provide no indication of whether or not the function may recover in the future, whether it is already on a trajectory for recovery, or may further degrade. As such, the conclusions that can be drawn for resilience over the longer term are limited. However, these studies nevertheless inform on the important aspect of to what extent a function was able to persist under disturbance, and thus - if measured in a standard way across systems - can help rank the resilience of functions in different agroecosystems subject to similar pressures (e.g. Cariveau et al., 2013; see also metrics of Category I, Ingrisch and Bahn, 2018). In this regard, several studies on plant disease suppression in soil are the exception by including longer term measurements of persistence and recovery. In addition, studies examining temporal variation of pollination and biological pest control after disturbance are still rare, but represent an important step in this direction (e.g. Macfadyen et al., 2011). These studies have yet to show their full potential in terms of resilience assessment by explicitly comparing trajectories of long-term persistence to undisturbed (dynamic) baselines (Egli et al., 2018; Ingrisch and Bahn, 2018).

(2) Particularly for functions above-ground, many measures of how communities, functional community structure and interactions are modified under different types of disturbance have been 
examined in agroecosystems. In the case of pollination, measures based on biodiversity appear to

1074

1075

1076

1077

1078 dominate even more than in the case of biological pest control compared to direct measures of persistence of the functions themselves. However, this trend could change due to the current development of trait-matching approaches in pollination studies. While trait-matching approaches are gaining ground in the context of pollination, they have yet to be developed in studies of biological pest control, despite strong benefits that can be expected in this field. In contrast to these functions above-ground, studies of disease control in soil rarely examine biodiversity-based indicators compared to direct measures of the function itself. Although the validity of biodiversitybased indicators is often still far from demonstrated (Egli et al. 2018; Section 2 \& Table 1), if confirmed these measures could give key indications of the resilience of functions to future disturbances (e.g. Oliver et al., 2015a; Scheffer et al., 2009).

\subsection{Conceptual hurdles and technical challenges}

The distinction between the two types of measures - direct function persistence (1) vs. biodiversity-based or other resilience indicators (2) - in fact represents far more than a difference in methods. In Figs. 3 \& 4, we highlight the essential differences in the questions they can each address. In fact, when addressing the resilience of (agro)ecosystem functions under EC, two superficially similar but fundamentally different questions can be examined:

(i) To what extent are ecosystem functions able to persist (recover, resist) under EC? (Fig. 3)

(ii) What is the impact of EC on the ability of ecosystem functions to persist (recover, resist) under further disturbance? (Fig. 4)

We hypothesize that a lack of clarity about which of these questions is being addressed compounds the profusion of resilience metrics, definitions and theoretical assumptions (Donohue et al., 2016; Egli et al., 2018; Weise et al. 2019), hindering the development of operational frameworks in agroecosystems. In question (i), direct assessment of the function's response to disturbance is 
both necessary and theoretically possible, using existing measures of (short or long-term) persistence or more sophisticated metrics involving e.g. function resistance and recovery (Ingrisch and Bahn, 2018). Indeed, in this case, the disturbance is considered to have already taken place in some, if not all, observable systems (Fig. 3). Critically, this means that systems with different resilience to a known disturbance can be compared in terms of baseline biodiversity or statistical properties, and associated resilience indicators either invalidated or confirmed (e.g. Cariveau et al., 2013; Génin et al., 2018; Isbell et al., 2015). Addressing question (i) is essential to increase our ability to predict (anticipate) the consequences of observed environmental change on agroecosystem functions. In contrast, in question (ii), the focus is on resilience to unknown, future disturbances. Observed changes may erode, increase or not affect function resilience to future disturbance (Fig. 4), thus forming a legacy of previous and current changes that influence a function's future responses. Since responses to future disturbance are not directly observable, the state of indicators after observed environmental disturbance is a critical tool for their prediction.

[Insert Figures 3 and 4 here]

\subsection{Going beyond: novel approaches to measuring resilience under environmental change}

Current trends and models give indications as to what disturbances can be expected in agroecosystems of different regions, cultivation systems and at different scales (Fig. 2) (Sala et al., 2000). As a result, experimental tests could theoretically go beyond the use of indicators by directly estimating the impact of observed disturbances on resilience to (likely) future disturbance. In practice, this comes down to examining the effects of combinations of known and likely disturbances on the resilience of functioning. Importantly, approaches testing effects of multiple disturbances have the potential to highlight critical interactions between them for the resilience of functioning (e.g. Mantyka-Pringle et al., 2012; Sasaki et al., 2015). 

of ecosystem functions are relatively rare, including outside agroecosystems (Sasaki et al., 2015).

1123

1124

1125

1126 Nevertheless, some examples reviewed above could be considered in this light, such as studies investigating the impact of local and landscape factors on biological pest control (e.g. Jonsson et al., 2015; Tamburini et al., 2016). In these studies, combinations of a 'press' (chronic) disturbance (e.g. landscape simplification) and a 'pulse' (e.g. tillage; Tamburini et al., 2016) are found to interactively affect the persistence of biological control. Testing experimental 'pulse' disturbances in agroecosystems occurring at the scale of fields (Fig. 2) could be a promising way to attain direct measures of engineering resilience by assessing function recovery rates. Indeed, small-scale, acute disturbances are likely to have relatively short trajectories of recovery at experimentally practicable spatial and temporal scales, and may not require the kind of long-term experiments needed to measure resilience to chronic disturbances occurring at large scales. However, in systems with a legacy of strong large-scale, chronic disturbance (e.g. very simplified landscapes; Tscharntke et al., 2012), we expect the speed of function recovery after small-scale 'pulses' to be slower than in less chronically disturbed systems (Tscharntke et al., 2012). In other words, measuring recovery rates from small-scale disturbances should inform about the relative engineering resilience of systems undergoing variable degrees of chronic, large-scale disturbance such as landscape simplification. If we further assume that the validity of slowing recovery rates as indicators for ecological resilience (Table 1; Scheffer et al., 2015) can be extended to biodiversity-driven functions in agroecosystems, then (using a space-for-time substitution; De Palma et al., 2018) these measures may also provide some indication of the functions' ecological resilience itself. Although still lacking empirically, this approach has recently been tested theoretically in modelled spatially explicit landscapes, yielding critical insights for practical application in agroecosystems (Leemput et al., 2018).

For chronic disturbances such as climate change occurring at a global level, empirical investigations at landscape or regional scales remain difficult. For this, other approaches have recently been applied and may represent promising alternatives. Using a 'trait-for-time' substitution, 
Kühsel and Blüthgen (2015) examined the resilience of pollinators to climate change by estimating species-specific temperature niches. They show that communities in intensively used landscapes are in fact likely to be more resilient to climate change, as they consist of species (mainly flies) that have broader temperature niches than communities in less disturbed landscapes that have not undergone filtering by land use intensification. While promising, it is still unclear, however, whether such traitfor-time approaches can provide evidence of resilience to climate change of agroecosystem functions (here pollination services) themselves. In this example, resilience of pollination services to further disturbance including climate change may in fact be lower when provided by climateresilient flies, because it is driven by a community with lower functional diversity (mainly generalists) compared to communities in less disturbed, low-intensity landscapes.

Other approaches to estimate resilience that go beyond some empirical constraints, such as the difficulty to perform experiments and collect data at sufficient spatiotemporal scales, involve statistical and/or theoretical modelling (Egli et al., 2018). For example, modelling of non-linearities in the response of agroecosystem functions to disturbance gradients sometimes uncovers thresholdlike changes that may be related to thresholds of ecological resilience (Concepción 2012, With 2002). However, due to the snapshot character of these studies, as discussed above, it is not known whether 'collapsed' functions after such thresholds are on trajectories to recover. In addition, it is also not theoretically known to what extent agroecosystem functions (not communities) are at all subject to thresholds or tipping points of ecological resilience, or instead go through gradual regime shifts when nearing collapse (Dakos et al., 2015). According to theoretical frameworks, communities of function providers outside agroecosystems appear to be subject to tipping points, as shown by recent attempts to model the robustness of communities responsible for providing a function to incremental loss of species. For example, dimension-reduced mutualistic network models have been applied to predict critical tipping points in empirical plant-pollinator communities (Gao et al., 2016; Jiang et al., 2018). In addition, eigenvector decomposition methods are being explored to identify best-indicator species of critical transitions in communities (Dakos, 2018). These examples provide 
support for the idea that community tipping points also take place in agroecosystems. However, to date, models of community or network resilience have not considered implications in terms of the resilience of associated functions, and appear to generally assume a positive relationship between resilience of a community and resilience of functioning (Jiang et al., 2018). However, if combined with measures of the effectiveness of organisms for service provision in crops, according, for instance, to the degree of trait-matching they exhibit with crops, these methods are promising in estimating resilience of agroecosystem functions to large-scale, chronic environmental disturbances in addition to disturbances at smaller spatial and temporal scales.

\subsection{Summary and conclusion: knowledge gaps and future needs}

In this paper, we have reviewed how the resilience of biodiversity-driven functions is, and could be, operationalized in agroecosystems under varying degrees of environmental disturbance.

We show that despite a large number of available indicators of resilience, few to date have yet demonstrated validity for biodiversity-driven functions in agroecosystems. Furthermore, studies of three key biodiversity-driven services in agroecosystems highlight that when available, approaches to resilience assessment differ widely between functions, as does the degree to which studies have assessed different dimensions (definitions) of resilience. Overall, we conclude that:

(1) Studies examining the resilience or resilience indicators of biological pest control, disease control in soil, and pollination show variable resilience of these functions to environmental disturbance, but generally low persistence (with exceptions) to land use intensification at local to landscape scales. In contrast, resilience to biotic invasions (pest and pathogen outbreaks, introduction or supplementation of exotic or native pollinators) varies between functions and may depend to a large extent on interactions with land use intensity. Limited data are currently available on the resilience of these functions to climate change, despite progress in assessing the resilience of communities (mainly pollinators) to this driver. 
(2) More studies are needed that directly measure or estimate engineering and ecological resilience of agroecosystem functions. Various approaches developed outside agroecosystems can represent useful blueprints both empirically (direct experimental assessments) and theoretically (indirect estimates and modelling). For this, clarity of concepts is key and we provide a break-down of the steps needed to effectively define the 
the Swedish Research Council FORMAS (grant number 2016-01511, project: 'Will seemingly

redundant predator communities maintain stable biological control in the future?'). M. Jonsson and

H. Friberg were financially supported by the Centre for Biological Control at the Swedish University of Agricultural Sciences. E.A. Martin and F. Requier received no specific grant from any funding agency in the public, commercial, or not-for-profit sectors.

References

Alabouvette, C., Olivain, C., Steinberg, C., 2006a. Biological control of plant diseases: the European situation. Eur. J. Plant Pathol. 114, 329-341. https://doi.org/10.1007/s10658-005-0233-0

Alabouvette, C., Raaijmakers, J., DE Boer, W., Notz, R., Défago, G., Steinberg, C., Lemanceau, P., 2006b. Concepts and Methods to Assess the Phytosanitary Quality of Soils. In: J. Bloem, D.W. Hopkins, A. Benedetti, Microbiological methods for assessing soil quality (p. 257-269).

Allen, C.R., Angeler, D.G., Cumming, G.S., Folke, C., Twidwell, D., Uden, D.R., 2016. Quantifying spatial resilience. J. Appl. Ecol. 53, 625-635. https://doi.org/10.1111/1365-2664.12634

Allen, C.R., Angeler, D.G., Garmestani, A.S., Gunderson, L.H., Holling, C.S., 2014. Panarchy: Theory and Application. Ecosystems 17, 578-589. https://doi.org/10.1007/s10021-013-9744-2

Anderson, S.H., Kelly, D., Ladley, J.J., Molloy, S., Terry, J., 2011. Cascading Effects of Bird Functional Extinction Reduce Pollination and Plant Density. Science 331, 1068-1071. https://doi.org/10.1126/science.1199092

Angeler, D.G., Allen, C.R., 2016. Quantifying resilience. J. Appl. Ecol. 53, 617-624. https://doi.org/10.1111/1365-2664.12649

European Commission, 2016. Greening. Agric. Rural Dev. - Eur. Comm. URL https://ec.europa.eu/agriculture/direct-support/greening_en (accessed 9.5.18).

Asteraki, E.J., Hanks, C.B., Clements, R.O., 1992. The impact of the chemical removal of the hedgebase flora on the community structure of carabid beetles (Col., Carabidae) and spiders (Araneae) of the field and hedge bottom. J. Appl. Entomol. 113, 398-406. https://doi.org/10.1111/j.1439-0418.1992.tb00680.x 
Bailey, R.M., 2010. Spatial and temporal signatures of fragility and threshold proximity in modelled semi-arid vegetation. Proc. R. Soc. Lond. B Biol. Sci. rspb20101750. https://doi.org/10.1098/rspb.2010.1750

Baker, K.F., Cook, R.J., 1974. Biological control of plant pathogens. WH Freeman and Company.

Balvanera, P., Pfisterer, A.B., Buchmann, N., He, J.-S., Nakashizuka, T., Raffaelli, D., Schmid, B., 2006. Quantifying the evidence for biodiversity effects on ecosystem functioning and services. Ecol. Lett. 9, 1146-1156. https://doi.org/10.1111/j.1461-0248.2006.00963.x

Banning, N.C., Murphy, D.V., 2008. Effect of heat-induced disturbance on microbial biomass and activity in forest soil and the relationship between disturbance effects and microbial community structure. Appl. Soil Ecol. 40, 109-119.

Bartomeus, I., Potts, S.G., Steffan-Dewenter, I., Vaissière, B.E., Woyciechowski, M., Krewenka, K.M., Tscheulin, T., Roberts, S.P.M., Szentgyörgyi, H., Westphal, C., Bommarco, R., 2014. Contribution of insect pollinators to crop yield and quality varies with agricultural intensification. PeerJ 2, e328. https://doi.org/10.7717/peerj.328

Bartomeus, I., Gravel, D., Tylianakis, J.M., Aizen, M.A., Dickie, I.A., Bernard-Verdier, M., 2016. A common framework for identifying linkage rules across different types of interactions. Funct. Ecol. 30, 1894-1903. https://doi.org/10.1111/1365-2435.12666

Barton, B.T., Ives, A.R., 2014. Species interactions and a chain of indirect effects driven by reduced precipitation. Ecology 95, 486-494. https://doi.org/10.1890/13-0044.1

Bestelmeyer, B.T., Duniway, M.C., James, D.K., Burkett, L.M., Havstad, K.M., 2013. A test of critical thresholds and their indicators in a desertification-prone ecosystem: more resilience than we thought. Ecol. Lett. 16, 339-345. https://doi.org/10.1111/ele.12045.

Bianchi, F.J., Booij, C.J.H., Tscharntke, T., 2006. Sustainable pest regulation in agricultural landscapes: a review on landscape composition, biodiversity and natural pest control. Proc. R. Soc. Lond. B Biol. Sci. 273, 1715-1727. https://doi.org/10.1098/rspb.2006.3530

Biesmeijer, J.C., Roberts, S.P.M., Reemer, M., Ohlemüller, R., Edwards, M., Peeters, T., Schaffers, A.P., Potts, S.G., Kleukers, K., Thomas, C.D., Settlele, J., Kunin, W.E., 2006. Parallel declines in pollinators and insectpollinated plants in Britain and the Netherlands. Science 313, 351-354. https://doi.org/10.1126/science.1127863

Biggs, R., Schlüter, M., Schoon, M.L., 2015. Principles for building resilience: sustaining ecosystem services in social-ecological systems. Cambridge University Press. 
Birkhofer, K., Bylund, H., Dalin, P., Ferlian, O., Gagic, V., Hambäck, P.A., Klapwijk, M., Mestre, L., Roubinet, E., Schroeder, M., Stenberg, J.A., Porcel, M., Björkman, C., Jonsson, M., 2017. Methods to identify the prey of invertebrate predators in terrestrial field studies. Ecol. Evol. https://doi.org/10.1002/ece3.2791

Boetzl, F.A., Krimmer, E., Krauss, J., Steffan-Dewenter, I., 2018. Agri-environmental schemes promote ground-dwelling predators in adjacent oilseed rape fields: Diversity, species traits and distance-decay functions. J. Appl. Ecol. https://doi.org/10.1111/1365-2664.13162

Bommarco, R., Kleijn, D., Potts, S.G., 2013. Ecological intensification: harnessing ecosystem services for food security. Trends Ecol. Evol. 28, 230-238. https://doi.org/10.1016/j.tree.2012.10.012

Bommarco, R., Marini, L., Vaissière, B.E., 2012. Insect pollination enhances seed yield, quality, and market value in oilseed rape. Oecologia 169, 1025-1032. https://doi.org/10.1007/s00442-0122271-6

Cabell, J., Oelofse, M., 2012. An Indicator Framework for Assessing Agroecosystem Resilience. Ecol. Soc. 17, 18. https://doi.org/10.5751/ES-04666-170118

Cadotte, M.W., Carscadden, K., Mirotchnick, N., 2011. Beyond species: Functional diversity and the maintenance of ecological processes and services. J. Appl. Ecol. 48, 1079-1087. https://doi.org/10.1111/j.1365-2664.2011.02048.x

Cameron, S.A., Lozier, J.D., Strange, J.P., Koch, J.B., Cordes, N., Solter, L.F., Griswold, T.L., 2011. Patterns of widespread decline in North American bumble bees. Proc. Natl. Acad. Sci. 108, 662-667. https://doi.org/10.1073/pnas.1014743108

Cariveau, D.P., Williams, N.M., Benjamin, F.E., Winfree, R., 2013. Response diversity to land use occurs but does not consistently stabilise ecosystem services provided by native pollinators. Ecol. Lett. 16, 903-911. https://doi.org/10.1111/ele.12126

Carpenter, S., Walker, B., Anderies, J.M., Abel, N., 2001. From Metaphor to Measurement: Resilience of What to What? Ecosystems 4, 765-781. https://doi.org/10.1007/s10021-001-0045-9

Carpenter, S.R., Brock, W.A., 2011. Early warnings of unknown nonlinear shifts: a nonparametric approach. Ecology 92, 2196-2201. https://doi.org/10.1890/11-0716.1

Carpenter, S.R., Brock, W.A., 2006. Rising variance: a leading indicator of ecological transition. Ecol. Lett. 9, 311-318. https://doi.org/10.1111/j.1461-0248.2005.00877.x 
Carvell, C., Meek, W.R., Pywell, R.F., Goulson, D., Nowakowski, M., 2007. Comparing the efficacy of agri-environment schemes to enhance bumble bee abundance and diversity on arable field margins. J. Appl. Ecol. 44, 29-40. https://doi.org/10.1111/j.1365-2664.2006.01249.x

Case, T.J., 1990. Invasion resistance arises in strongly interacting species-rich model competition communities. Proc. Natl. Acad. Sci. 87, 9610-9614. https://doi.org/10.1073/pnas.87.24.9610

Caves, E.M., Jennings, S.B., HilleRisLambers, J., Tewksbury, J.J., Rogers, H.S., 2013. Natural Experiment Demonstrates That Bird Loss Leads to Cessation of Dispersal of Native Seeds from Intact to Degraded Forests. PLOS ONE 8, e65618. https://doi.org/10.1371/journal.pone.0065618

Chapin, F.S., Walker, B.H., Hobbs, R.J., Hooper, D.U., Lawton, J.H., Sala, O.E., Tilman, D., 1997. Biotic control over the functioning of ecosystems. Science $277,500-504$. https://doi.org/10.1126/science.277.5325.500

Concepción, E.D., Díaz, M., Kleijn, D., Báldi, A., Batáry, P., Clough, Y., Gabriel, D., Herzog, F., Holzschuh, A., Knop, E., 2012. Interactive effects of landscape context constrain the effectiveness of local agri-environmental management. J. Appl. Ecol. 49, 695-705. https://doi.org/10.1111/j.1365-2664.2012.02131.x

Cook, R.J., 1993. Making greater use of introduced microorganisms for biological control of plant pathogens. Annu. Rev. Phytopathol. 31, 53-80.

Dai, L., Korolev, K.S., Gore, J., 2013. Slower recovery in space before collapse of connected populations. Nature 496, 355-358. https://doi.org/10.1038/nature12071

Dakos, V., 2018. Identifying best-indicator species for abrupt transitions in multispecies communities. Ecol. Indic. 94, 494-502. https://doi.org/10.1016/j.ecolind.2017.10.024

Dakos, V., Carpenter, S.R., Nes, E.H. van, Scheffer, M., 2015. Resilience indicators: prospects and limitations for early warnings of regime shifts. Philos. Trans. R. Soc. Lond. B Biol. Sci. 370, 20130263. https://doi.org/10.1098/rstb.2013.0263

Dakos, V., Kéfi, S., Rietkerk, M., Van Nes, E.H., Scheffer, M., 2011. Slowing down in spatially patterned ecosystems at the brink of collapse. Am. Nat. 177, E153-E166. https://doi.org/10.1086/659945.

Dakos, V., Van Nes, E.H., D'Odorico, P., Scheffer, M., 2012. Robustness of variance and autocorrelation as indicators of critical slowing down. Ecology 93, 264-271. https://doi.org/10.1890/11-0889.1 
Dakos, V., van Nes, E.H., Donangelo, R., Fort, H., Scheffer, M., 2010. Spatial correlation as leading indicator of catastrophic shifts. Theor. Ecol. 3, 163-174. https://doi.org/10.1007/s12080-0090060-6

Darnhofer, I., Bellon, S., Dedieu, B., Milestad, R., 2010. Adaptiveness to enhance the sustainability of farming systems. A review. Agron. Sustain. Dev. 30, 545-555. https://doi.org/10.1051/agro/2009053

De Bello, F., Thuiller, W., Lepš, J., Choler, P., Clément, J.-C., Macek, P., Sebastià, M.-T., Lavorel, S., 2009. Partitioning of functional diversity reveals the scale and extent of trait convergence and divergence. J. Veg. Sci. 20, 475-486. https://doi.org/10.1111/j.1654-1103.2009.01042.x

De Palma, A., Sanchez-Ortiz, K., Martin, P.A., Chadwick, A., Gilbert, G., Bates, A.E., Börger, L., Contu, S., Hill, S.L.L., Purvis, A., 2018. Chapter Four - Challenges With Inferring How Land-Use Affects Terrestrial Biodiversity: Study Design, Time, Space and Synthesis, in: Bohan, D.A., Dumbrell, A.J., Woodward, G., Jackson, M. (Eds.), Advances in Ecological Research, Next Generation Biomonitoring: Part 1. Academic Press, pp. 163-199. https://doi.org/10.1016/bs.aecr.2017.12.004

Deng, H., 2012. A review of diversity-stability relationship of soil microbial community: What do we not know? J. Environ. Sci. 24, 1027-1035. https://doi.org/10.1016/S1001-0742(11)60846-2

Deutsch, C.A., Tewksbury, J.J., Tigchelaar, M., Battisti, D.S., Merrill, S.C., Huey, R.B., Naylor, R.L., 2018. Increase in crop losses to insect pests in a warming climate. Science 361, 916-919. https://doi.org/10.1126/science.aat3466

Díaz, S., Purvis, A., Cornelissen, J.H., Mace, G.M., Donoghue, M.J., Ewers, R.M., Jordano, P., Pearse, W.D., 2013. Functional traits, the phylogeny of function, and ecosystem service vulnerability. Ecol. Evol. 3, 2958-2975. https://doi.org/10.1002/ece3.601

Diehl, E., Wolters, V., Birkhofer, K., 2012. Arable weeds in organically managed wheat fields foster carabid beetles by resource- and structure-mediated effects. Arthropod-Plant Interact. 6, 7582. https://doi.org/10.1007/s11829-011-9153-4

Diffenbaugh, N.S., Krupke, C.H., White, M.A., Alexander, C.E., 2008. Global warming presents new challenges for maize pest management. Environ. Res. Lett. 3. https://doi.org/10.1088/1748$9326 / 3 / 4 / 044007$

Díaz, S., Cabido, M., 2001. Vive la différence: plant functional diversity matters to ecosystem processes. Trends Ecol. Evol. 16, 646-655. https://doi.org/10.1016/S0169-5347(01)02283-2 
Donohue, I., Hillebrand, H., Montoya, J.M., Petchey, O.L., Pimm, S.L., Fowler, M.S., Healy, K., Jackson, A.L., Lurgi, M., McClean, D., O'Connor, N.E., O'Gorman, E.J., Yang, Q., 2016. Navigating the complexity of ecological stability. Ecol. Lett. 19, 1172-1185. https://doi.org/10.1111/ele.12648

Döring, T.F., Vieweger, A., Pautasso, M., Vaarst, M., Finckh, M.R., Wolfe, M.S., 2013. Resilience as a universal criterion of health. J. Sci. Food Agric. 95, 455-465. https://doi.org/10.1002/jsfa.6539

Drieu, R., Rusch, A., 2017. Conserving species-rich predator assemblages strengthens natural pest control in a climate warming context. Agric. For. Entomol. 19, 52-59. https://doi.org/10.1111/afe.12180

Duflot, R., Georges, R., Ernoult, A., Aviron, S., Burel, F., 2014. Landscape heterogeneity as an ecological filter of species traits. Acta Oecologica 56, 19-26. https://doi.org/10.1016/j.actao.2014.01.004

Dunne, J.A., Williams, R.J., Martinez, N.D., 2002. Network structure and biodiversity loss in food webs: robustness increases with connectance. Ecol. Lett. 5, 558-567. https://doi.org/10.1046/j.1461-0248.2002.00354.x

Egli, L., Weise, H., Radchuk, V., Seppelt, R., Grimm, V., 2018. Exploring resilience with agent-based models: State of the art, knowledge gaps and recommendations for coping with multidimensionality. Ecol. Complex. https://doi.org/10.1016/j.ecocom.2018.06.008

Eilenberg, J., Hajek, A., Lomer, C., 2001. Suggestions for unifying the terminology in biological control. BioControl 46, 387-400.

Eisenhauer, N., Schulz, W., Scheu, S., Jousset, A., 2013. Niche dimensionality links biodiversity and invasibility of microbial communities. Funct. Ecol. 27, 282-288. https://doi.org/10.1111/j.1365-2435.2012.02060.x

Elbgami, T., Kunin, W.E., Hughes, W.O.H., Biesmeijer, J.C., 2014. The effect of proximity to a honeybee apiary on bumblebee colony fitness, development, and performance. Apidologie 45, 504-513. https://doi.org/10.1007/s13592-013-0265-y

Elead, Y., Köhl, J., Fokkema, N.J., 1994. Control of infection and sporulation ofBotrytis cinerea on bean and tomato by saprophytic bacteria and fungi. Eur. J. Plant Pathol. 100, 315-336. https://doi.org/10.1007/BF01876443 
Elmqvist, T., Folke, C., Nyström, M., Peterson, G., Bengtsson, J., Walker, B., Norberg, J., 2003. Response diversity, ecosystem change, and resilience. Front. Ecol. Environ. 1, 488-494. https://doi.org/10.1890/1540-9295(2003)001[0488:RDECAR]2.0.CO;2

Elton, C.S., 1958. The ecology of invasions by animals and plants. Methuen, London, UK.

Fahrig, L., Baudry, J., Brotons, L., Burel, F.G., Crist, T.O., Fuller, R.J., Sirami, C., Siriwardena, G.M., Martin, J.-L., 2011. Functional landscape heterogeneity and animal biodiversity in agricultural landscapes. Ecol. Lett. 14, 101-112. https://doi.org/10.1111/j.1461-0248.2010.01559.x

Fargione, J.E., Tilman, D., 2005. Diversity decreases invasion via both sampling and complementarity effects. Ecol. Lett. 8, 604-611. https://doi.org/10.1111/j.1461-0248.2005.00753.x

Faria, D., Laps, R.R., Baumgarten, J., Cetra, M., 2006. Bat and bird assemblages from forests and shade cacao plantations in two contrasting landscapes in the Atlantic Forest of southern Bahia, Brazil. Biodivers. Conserv. 15, 587-612. https://doi.org/10.1007/s10531-005-2089-1

Farwig, N., Schabo, D.G., Albrecht, J., 2017. Trait-associated loss of frugivores in fragmented forest does not affect seed removal rates. J. Ecol. 105, 20-28. https://doi.org/10.1111/13652745.12669

Fitter, A.H., Fitter, R.S.R., 2002. Rapid Changes in Flowering Time in British Plants. Science 296, 16891691. https://doi.org/10.1126/science.1071617

Foley, J.A., Ramankutty, N., Brauman, K.A., Cassidy, E.S., Gerber, J.S., Johnston, M., Mueller, N.D., O'Connell, C., Ray, D.K., West, P.C., 2011. Solutions for a cultivated planet. Nature 478, 337. https://doi.org/10.1038/nature10452

Folke, C., Carpenter, S., Walker, B., Scheffer, M., Elmqvist, T., Gunderson, L., Holling, C.S., 2004. Regime shifts, resilience, and biodiversity in ecosystem management. Annu. Rev. Ecol. Evol. Syst. 35, 557-581. https://doi.org/10.1146/annurev.ecolsys.35.021103.105711

Folke, C., Carpenter, S.R., Walker, B., Scheffer, M., Chapin, T., Rockström, J., 2010. Resilience Thinking: Integrating Resilience, Adaptability and Transformability. Ecol. Soc. 15.

Fonseca, C.R., Ganade, G., 2001. Species functional redundancy, random extinctions and the stability of ecosystems. J. Ecol. 89, 118-125. https://doi.org/10.1046/j.1365-2745.2001.00528.x

Fontaine, C., Dajoz, I., Meriguet, J., Loreau, M., 2005. Functional diversity of plant-pollinator interaction webs enhances the persistence of plant communities. PLoS Biol. 4, e1. https://doi.org/10.1371/journal.pbio.0040001 
Friberg, H., Edel-Hermann, V., Faivre, C., Gautheron, N., Fayolle, L., Faloya, V., Montfort, F., Steinberg, C., 2009. Cause and duration of mustard incorporation effects on soil-borne plant pathogenic fungi. Soil Biol. Biochem. 41, 2075-2084. https://doi.org/10.1016/j.soilbio.2009.07.017

Frost, C.M., Peralta, G., Rand, T.A., Didham, R.K., Varsani, A., Tylianakis, J.M., 2016. Apparent competition drives community-wide parasitism rates and changes in host abundance across ecosystem boundaries. Nat. Commun. 7, 12644. https://doi.org/10.1038/ncomms12644

Furlong, M.J., Zalucki, M.P., 2017. Climate change and biological control: the consequences of increasing temperatures on host-parasitoid interactions. Curr. Opin. Insect Sci. 20, 39-44. https://doi.org/10.1016/J.COIS.2017.03.006

Gabriel, D., Tscharntke, T. 2007. Insect pollinated plants benefit from organic farming. Agric. Ecosyst. Environ. 118, 43-48. https://doi.org/10.1016/j.agee.2006.04.005

Gagic, V., Bartomeus, I., Jonsson, T., Taylor, A., Winqvist, C., Fischer, C., Slade, E.M., SteffanDewenter, I., Emmerson, M., Potts, S.G., Tscharntke, T., Weisser, W., Bommarco, R., 2015. Functional identity and diversity of animals predict ecosystem functioning better than speciesbased indices. Proc. R. Soc. Lond. B Biol. Sci. 282, 20142620. https://doi.org/10.1098/rspb.2014.2620

Gagic, V., Hänke, S., Thies, C., Scherber, C., Tomanović, Ž., Tscharntke, T., 2012. Agricultural intensification and cereal aphid-parasitoid-hyperparasitoid food webs: Network complexity, temporal variability and parasitism rates. Oecologia 170, 1099-1109. https://doi.org/10.1007/s00442-012-2366-0

Gagic, V., Kleijn, D., Báldi, A., Boros, G., Jørgensen, H.B., Elek, Z., Garratt, M.P.D., de Groot, G.A., Hedlund, K., Kovács-Hostyánszki, A., Marini, L., Martin, E., Pevere, I., Potts, S.G., Redlich, S., Senapathi, D., Steffan-Dewenter, I., Świtek, S., Smith, H.G., Takács, V., Tryjanowski, P., van der Putten, W.H., van Gils, S., Bommarco, R., 2017. Combined effects of agrochemicals and ecosystem services on crop yield across Europe. Ecol. Lett. 20, 1427-1436. https://doi.org/10.1111/ele.12850

Gao, J., Barzel, B., Barabási, A.-L., 2016. Universal resilience patterns in complex networks. Nature 530, 307-312. https://doi.org/10.1038/nature16948 
Garratt, M.P.D., Breeze, T.D., Jenner, N., Polce, C., Biesmeijer, J.C., Potts, S.G. 2014. Avoiding a bad apple: Insect pollination enhances fruit quality and economic value. Agric. Ecosyst. Environ. 184, 34-40. https://doi.org/10.1016/j.agee.2013.10.032

García, D., Martínez, D., Herrera, J.M., Morales, J.M., 2013. Functional heterogeneity in a plantfrugivore assemblage enhances seed dispersal resilience to habitat loss. Ecography 36, 197208. https://doi.org/10.1111/j.1600-0587.2012.07519.x

Garibaldi, L.A., Aizen, M.A., Cunningham, S., Klein, A.M., 2009a. Pollinator shortage and global crop yield. Commun. Integr. Biol. 2, 37-39. https://doi.org/10.4161/cib.2.1.7425

Garibaldi, L.A., Bartomeus, I., Bommarco R., Klein A.M., Cunningham S.A., Aizen M.A., Boreux V., Garratt M.P.D., Carvalheiro L.G., Kremen C., Morales C.L., Schüepp C., Chacoff N.P., Freitas Breno M., Gagic V., Holzschuh A., Klatt B.K., Krewenka K.M., Krishnan S., Mayfield M.M., Motzke I., Otieno M., Petersen J., Potts S.G., Ricketts T.H., Rundlöf M., Sciligo A., Sinu Palatty A., Steffan-Dewenter I., Taki H., Tscharntke T., Vergara C.H., Viana B.F., Woyciechowski M., Devictor V., 2015. EDITOR'S CHOICE: REVIEW: Trait matching of flower visitors and crops predicts fruit set better than trait diversity. J. Appl. Ecol. 52, 1436-1444. https://doi.org/10.1111/1365-2664.12530

Garibaldi, L.A., Requier, F., Rollin, O., Andersson, G.K.S., 2017. Towards an integrated species and habitat management of crop pollination. Curr. Opin. Insect Sci. 21, 1-10. https://doi.org/10.1016/j.cois.2017.05.016

Geldmann, J., González-Varo, J.P., 2018. Conserving honey bees does not help wildlife. Science 359, 392-393. https://doi.org/10.1126/science.aar2269

Geiger, F., Bengtsson, J., Berendse, F., Weisser, W.W., Emmerson, M., Morales, M.B., Ceryngier, P., Liira, J., Tscharntke, T., Winqvist, C., Eggers, S., Bommarco, R., Pärt, T., Bretagnolle, V., Plantegenest, M., Clement, L.W., Dennis, C., Palmer, C., Oñate, J.J., Guerrero, I., Hawro, V., Aavik, T., Thies, C., Flohre, A., Hänke, S., Fischer, C., Goedhart, P.W., Inchausti, P., 2010. Persistent negative effects of pesticides on biodiversity and biological control potential on European farmland. Basic Appl. Ecol. 11, 97-105. https://doi.org/10.1016/j.baae.2009.12.001

Génin, A., Majumder, S., Sankaran, S., Schneider, F.D., Danet, A., Berdugo, M., Guttal, V., Kéfi, S., 2018. Spatially heterogeneous stressors can alter the performance of indicators of regime shifts. Ecol. Indic. 94, 520-533. https://doi.org/10.1016/j.ecolind.2017.10.071 
Geslin B., Gauzens, B., Baude, M., Dajoz, I., Fontaine, C., Henry, M., Ropars, L., Rollin, O., Thébault, E., Vereecken, N.J., 2017. Chapter Four - Massively Introduced Managed Species and Their Consequences for Plant-Pollinator Interactions. Advances in Ecological Research, Networks of Invasion : Empirical Evidence and Case Studies. Academic Press, pp. 147-199. https://doi.org/10.1016/bs.aecr.2016.10.007

González-Varo, J.P., Carvalho, C.S., Arroyo, J.M., Jordano, P., 2017. Unravelling seed dispersal through fragmented landscapes: Frugivore species operate unevenly as mobile links. Mol. Ecol. 26, 4309-4321. https://doi.org/10.1111/mec.14181

González-Varo, J.P., Geldmann, J., 2018. Response to Comments of "Conserving honey bees does not help wildlife" Science 360, 390.

Gossner, M.M., Simons, N.K., Achtziger, R., Blick, T., Dorow, W.H., Dziock, F., Köhler, F., Rabitsch, W., Weisser, W.W., 2015. A summary of eight traits of Coleoptera, Hemiptera, Orthoptera and Araneae, occurring in grasslands in Germany. Sci. Data 2, 150013.

Goulson, D., Lye, G.C., Darvill, B., 2008. Decline and Conservation of Bumble Bees. Annu. Rev. Entomol. 53, 191-208.

Goulson, D., Nicholls, E., Botias, C., Rotheray, E.L., 2015. Bee declines driven by combined stress from parasites, pesticides, and lack of flowers. Science, 347, 1255957.

Goulson, D., Sparrow, K.R., 2009. Evidence for competition between honeybees and bumblebees; effects on bumblebee worker size. J. Insect Conserv. 13, 177-181.

Griffiths, B., Ritz, K., Wheatley, R., Kuan, H., Boag, B., Christensen, S., Ekelund, F., Sørensen, S., Muller, S., Bloem, J., 2001. An examination of the biodiversity-ecosystem function relationship in arable soil microbial communities. Soil Biol. Biochem. 33, 1713-1722. https://doi.org/10.1016/S0038-0717(01)00094-3

Griffiths, B.S., Philippot, L., 2013. Insights into the resistance and resilience of the soil microbial community. FEMS Microbiol. Rev. 37, 112-129. https://doi.org/10.1111/j.1574$6976.2012 .00343 . x$

Grime, J.P., 1998. Benefits of plant diversity to ecosystems: immediate, filter and founder effects. J. Ecol. 86, 902-910. https://doi.org/10.1046/j.1365-2745.1998.00306.x

Grimm, V., Wissel, C., 1997. Babel, or the ecological stability discussions: an inventory and analysis of terminology and a guide for avoiding confusion. Oecologia 109, 323-334. https://doi.org/10.1007/s004420050090 
Guetsky, R., Shtienberg, D., Elad, Y., Dinoor, A., 2001. Combining Biocontrol Agents to Reduce the Variability of Biological Control. Phytopathology 91, 621-627. https://doi.org/10.1094/PHYTO.2001.91.7.621

Hallett, A.C., Mitchell, R.J., Chamberlain, E.R., Karron, J.D., 2017. Pollination success following loss of a frequent pollinator: the role of compensatory visitation by other effective pollinators. AoB Plants 9.

Hasna, M.K., Mårtensson, A., Persson, P., Rämert, B., 2007. Use of composts to manage corky root disease in organic tomato production. Ann. Appl. Biol. 151, 381-390. https://doi.org/10.1111/j.1744-7348.2007.00178.x

Henry, M., Beguin, M., Requier, F., Rollin, O., Odoux, J.F., Aupinel, P., Aptel, J., Tchamitchian, S., Decourtye, A., 2012. A common Pesticide Decreases Foraging Success and Survival in Honey Bees. Science 336, 348-350.

Hillebrand, H., 2004. On the Generality of the Latitudinal Diversity Gradient. Am. Nat. 163, 192-211. https://doi.org/10.1086/381004

Ho, W.C., Ko, W.H., 1982. Characteristics of soil microbiostasis. Soil Biol. Biochem. 14, 589-593. https://doi.org/10.1016/0038-0717(82)90092-X

Hodgson, D., McDonald, J.L., Hosken, D.J., 2015. What do you mean, 'resilient'? Trends Ecol. Evol. 30, 503-506. https://doi.org/10.1016/j.tree.2015.06.010

Holling, C.S., 1988. Temperate forest insect outbreaks, tropical deforestation and migratory birds. Mem. Entomol. Soc. Can. 120, 21-32. https://doi.org/10.4039/entm120146021-1

Holling, C.S., 1973. Resilience and stability of ecological systems. Annu. Rev. Ecol. Syst. 4, 1-23.

Holzschuh, A., Dudenhöffer, J.H., Tscharntke, T., 2012. Landscapes with wild bee habitats enhance pollination, fruit set and yield of sweet cherry. Biol. Conserv. 153, 101-107.

Holzschuh, A., Steffan-Dewenter, I., Kleijn, D., Tscharntke, T., 2007. Diversity of flower-visiting bees in cereal fields: effects of farming system, landscape composition and regional context. J. Appl. Ecol. 44, 41-49.

Hooper, D.U., Adair, E.C., Cardinale, B.J., Byrnes, J.E.K., Hungate, B.A., Matulich, K.L., Gonzalez, A., Duffy, J.E., Gamfeldt, L., O’Connor, M.I., 2012. A global synthesis reveals biodiversity loss as a major driver of ecosystem change. Nature 486, 105-108. https://doi.org/10.1038/nature11118 
Hooper, D.U., Chapin, F.S., Ewel, J.J., Hector, A., Inchausti, P., Lavorel, S., Lawton, J.H., Lodge, D.M., Loreau, M., Naeem, S., Schmid, B., Setala, H., Symstad, A.J., Vandermeer, J., Wardle, D.A., 2005. Effects of biodiversity on ecosystem functioning: a consensus of current knowledge. Ecol. Monogr. 75, 3-35. https://doi.org/10.1890/04-0922

Houlahan, J.E., Currie, D.J., Cottenie, K., Cumming, G.S., Ernest, S.K.M., Findlay, C.S., Fuhlendorf, S.D., Gaedke, U., Legendre, P., Magnuson, J.J., McArdle, B.H., Muldavin, E.H., Noble, D., Russell, R., Stevens, R.D., Willis, T.J., Woiwod, I.P., Wondzell, S.M., 2007. Compensatory dynamics are rare in natural ecological communities. Proc. Natl. Acad. Sci. 104, 3273-3277. https://doi.org/10.1073/pnas.0603798104

Hudewenz, A., Klein, A.M., 2013. Competition between honey bees and wild bees and the role of nesting resources in a nature reserve. J. Insect Conserv. 17, 1275-1283.

Ingrisch, J., Bahn, M., 2018. Towards a comparable quantification of resilience. Trends Ecol. Evol. 33, 251-259. https://doi.org/10.1016/j.tree.2018.01.013

Irikiin, Y., Nishiyama, M., Otsuka, S., Senoo, K., 2006. Rhizobacterial community-level, sole carbon source utilization pattern affects the delay in the bacterial wilt of tomato grown in rhizobacterial community model system. Appl. Soil Ecol. 34, 27-32. https://doi.org/10.1016/j.apsoil.2005.12.003

Isaacs, R., Williams, N., Ellis, J., Pitts-Singer, T.L., Bommarco, R., Vaughan, M., 2017. Integrated Crop Pollination: Combining strategies to ensure stable and sustainable yields of pollinationdependent crops. Basic Appl. Ecol. 22, 44-60.

Isbell, F., Craven, D., Connolly, J., Loreau, M., Schmid, B., Beierkuhnlein, C., Bezemer, T.M., Bonin, C., Bruelheide, H., Luca, E. de, Ebeling, A., Griffin, J.N., Guo, Q., Hautier, Y., Hector, A., Jentsch, A., Kreyling, J., Lanta, V., Manning, P., Meyer, S.T., Mori, A.S., Naeem, S., Niklaus, P.A., Polley, H.W., Reich, P.B., Roscher, C., Seabloom, E.W., Smith, M.D., Thakur, M.P., Tilman, D., Tracy, B.F., Putten, W.H. van der, Ruijven, J. van, Weigelt, A., Weisser, W.W., Wilsey, B., Eisenhauer, N., 2015. Biodiversity increases the resistance of ecosystem productivity to climate extremes. Nature 526, 574-577. https://doi.org/10.1038/nature15374

Jiang, J., Huang, Z.-G., Seager, T.P., Lin, W., Grebogi, C., Hastings, A., Lai, Y.-C., 2018. Predicting tipping points in mutualistic networks through dimension reduction. Proc. Natl. Acad. Sci. 115, E639-E647. https://doi.org/10.1073/pnas.1714958115 
Joner, F., Specht, G., Müller, S.C., Pillar, V.D., 2011. Functional redundancy in a clipping experiment on grassland plant communities. Oikos 120, 1420-1426. https://doi.org/10.1111/j.16000706.2011.19375.x

Jonsson, M., Kaartinen, R., Straub, C.S., 2017. Relationships between natural enemy diversity and biological control. Curr. Opin. Insect Sci. 20, 1-6. https://doi.org/10.1016/j.cois.2017.01.001

Jonsson, M., Straub, C.S., Didham, R.K., Buckley, H.L., Case, B.S., Hale, R.J., Gratton, C., Wratten, S.D., 2015. Experimental evidence that the effectiveness of conservation biological control depends on landscape complexity. J. Appl. Ecol. 52, 1274-1282. https://doi.org/10.1111/13652664.12489

Kalda, O., Kalda, R., Liira, J., 2015. Multi-scale ecology of insectivorous bats in agricultural landscapes. Agric. Ecosyst. Environ. 199, 105-113. https://doi.org/10.1016/j.agee.2014.08.028

Karp, D.S., Chaplin-Kramer, R., Meehan, T.D., Martin, E.A., DeClerck, F., Grab, H., Gratton, C., Hunt, L., Larsen, A.E., Martínez-Salinas, A., O’Rourke, M.E., Rusch, A., Poveda, K., Jonsson, M., Rosenheim, J.A., Schellhorn, N.A., Tscharntke, T., Wratten, S.D., Zhang, W., Iverson, A.L., Adler, L.S., Albrecht, M., Alignier, A., Angelella, G.M., Zubair Anjum, M., Avelino, J., Batáry, P., Baveco, J.M., Bianchi, F.J.J.A., Birkhofer, K., Bohnenblust, E.W., Bommarco, R., Brewer, M.J., Caballero-López, B., Carrière, Y., Carvalheiro, L.G., Cayuela, L., Centrella, M., Ćetković, A., Henri, D.C., Chabert, A., Costamagna, A.C., De la Mora, A., de Kraker, J., Desneux, N., Diehl, E., Diekötter, T., Dormann, C.F., Eckberg, J.O., Entling, M.H., Fiedler, D., Franck, P., Frank van Veen, F.J., Frank, T., Gagic, V., Garratt, M.P.D., Getachew, A., Gonthier, D.J., Goodell, P.B., Graziosi, I., Groves, R.L., Gurr, G.M., Hajian-Forooshani, Z., Heimpel, G.E., Herrmann, J.D., Huseth, A.S., Inclán, D.J., Ingrao, A.J., Iv, P., Jacot, K., Johnson, G.A., Jones, L., Kaiser, M., Kaser, J.M., Keasar, T., Kim, T.N., Kishinevsky, M., Landis, D.A., Lavandero, B., Lavigne, C., Le Ralec, A., Lemessa, D., Letourneau, D.K., Liere, H., Lu, Y., Lubin, Y., Luttermoser, T., Maas, B., Mace, K., Madeira, F., Mader, V., Cortesero, A.M., Marini, L., Martinez, E., Martinson, H.M., Menozzi, P., Mitchell, M.G.E., Miyashita, T., Molina, G.A.R., Molina-Montenegro, M.A., O'Neal, M.E., Opatovsky, I., Ortiz-Martinez, S., Nash, M., Östman, Ö., Ouin, A., Pak, D., Paredes, D., Parsa, S., Parry, H., Perez-Alvarez, R., Perović, D.J., Peterson, J.A., Petit, S., Philpott, S.M., Plantegenest, M., Plećaš, M., Pluess, T., Pons, X., Potts, S.G., Pywell, R.F., Ragsdale, D.W., Rand, T.A., Raymond, L., Ricci, B., Sargent, C., Sarthou, J.-P., Saulais, J., Schäckermann, J., Schmidt, N.P., Schneider, G., Schüepp, C., Sivakoff, F.S., Smith, H.G., Stack Whitney, K., Stutz, S., Szendrei, Z., Takada, M.B., Taki, H., Tamburini, G., Thomson, L.J., Tricault, Y., Tsafack, N., Tschumi, M., Valantin-Morison, M., Van Trinh, M., van der Werf, W., Vierling, K.T., Werling, B.P., Wickens, 

2018. Crop pests and predators exhibit inconsistent responses to surrounding landscape composition. Proc. Natl. Acad. Sci. 115, E7863-E7870. https://doi.org/10.1073/pnas.1800042115

Karp, D.S., Ziv, G., Zook, J., Ehrlich, P.R., Daily, G.C., 2011. Resilience and stability in bird guilds across tropical countryside. Proc. Natl. Acad. Sci. 108, 21134-21139. https://doi.org/10.1073/pnas.1118276108

Kennedy, C.M., Lonsdorf, E., Neel, M.C., Williams, N.M., Ricketts, T.H., Winfree, R., Bommarco, R., Brittain, C., Burley, A.L., Cariveau, D., Carvalheiro, L.G., Chacoff, N.P., Cunningham, S.A., Danforth, B.N., Dudenhöffer, J.H., Elle, E., Gaines, H.R., Garibaldi, L.A., Gratton, C., Holzschuh, A., Isaacs, R., Javorek, S.K., Jha, S., Klein, A.M., Krewenka, K., Mandelik, Y., Mayfield, M.M., Morandin, L., Neame, L.A., Otieno, M., Park, M., Potts, S.G., Rundlöf, M., Saez, A., SteffanDewenter, I., Taki, H., Viana, B.F., Westphal, C., Wilson, J.K., Greenleaf, S.S., Kremen, C., 2013. A global quantitative synthesis of local and landscape effects on wild bee pollinators in agroecosystems. Ecol. Lett. 16, 584-99.

Kinkel, L.L., Bakker, M.G., Schlatter, D.C., 2011. A Coevolutionary Framework for Managing DiseaseSuppressive Soils. Annu. Rev. Phytopathol. 49, 47-67. https://doi.org/10.1146/annurev-phyto072910-095232

Klein, A.-M., Vaissiere, B.E., Cane, J.H., Steffan-Dewenter, I., Cunningham, S.A., Kremen, C., Tscharntke, T., 2007. Importance of pollinators in changing landscapes for world crops. Proc. R. Soc. Lond. B Biol. Sci. 274, 303-313.

Korenko, S., Niedobová, J., Kolářová, M., Hamouzová, K., Kysilková, K., Michalko, R., 2016. The effect of eight common herbicides on the predatory activity of the agrobiont spider Pardosa agrestis. BioControl 61, 507-517. https://doi.org/10.1007/s10526-016-9729-0

Krauss, J., Gallenberger, I., Steffan-Dewenter, I., 2011. Decreased Functional Diversity and Biological Pest Control in Conventional Compared to Organic Crop Fields. PLOS ONE 6, e19502. https://doi.org/10.1371/journal.pone.0019502

Kremen, C., M'Gonigle, L.K. 2015. Small-scale restoration in intensive agricultural landscapes supports more specialized and less mobile pollinator species. J. Appl. Ecol. 52, 602-610.

Kremen, C., Williams, N.M., Thorp, R.W., 2002. Crop pollination from native bees at risk from agricultural intensification. Proc. Natl. Acad. Sci. 99, 16812-16816. 
Kruess, A., Tscharntke, T., 2000. Species richness and parasitism in a fragmented landscape: Experiments and field studies with insects on Vicia sepium. Oecologia 122, 129-137. https://doi.org/10.1007/PL00008829

Kruess, A., Tscharntke, T., 1994. Habitat Fragmentation, Species Loss, and Biological Control. Science 264, 1581-1584. https://doi.org/10.1126/science.264.5165.1581

Kühsel, S., Blüthgen, N., 2015. High diversity stabilizes the thermal resilience of pollinator communities in intensively managed grasslands. Nat. Commun. 6, ncomms8989. https://doi.org/10.1038/ncomms8989

Laliberté, E., Tylianakis, J.M., 2010. Deforestation homogenizes tropical parasitoid-host networks. Ecology 91, 1740-1747. https://doi.org/10.1890/09-1328.1

Landis, D.A., Wratten, S.D., Gurr, G.M., 2000. Habitat Management to Conserve Natural Enemies of Arthropod Pests in Agriculture. Annu. Rev. Entomol. 45, 175-201. https://doi.org/10.1146/annurev.ento.45.1.175

Larkin, R. P., 2015. Soil health paradigms and implications for disease management. Annu. Rev. Phytopathol. 53:199-221. https://doi.org/10.1146/annurev-phyto-080614-120357

Larkin, R., 1996. Suppression of Fusarium Wilt of Watermelon by Nonpathogenic Fusarium oxysporum and Other Microorganisms Recovered from a Disease-Suppressive Soil. Phytopathology 86, 812. https://doi.org/10.1094/Phyto-86-812

Larsen, T.H., Williams, N.M., Kremen, C., 2005. Extinction order and altered community structure rapidly disrupt ecosystem functioning. Ecol. Lett. 8, 538-547. https://doi.org/10.1111/j.14610248.2005.00749.x

Latz, E., Eisenhauer, N., Rall, B. C., Scheu, S., Jousset, A. 2016. Unravelling linkages between plant community composition and the pathogen-suppressive potential of soils. Sci. Rep.-UK 6: 23584. https://doi.org/10.1038/srep23584

Lavorel, S., Garnier, E., 2002. Predicting changes in community composition and ecosystem functioning from plant traits: revisiting the Holy Grail. Funct. Ecol. 16, 545-556. https://doi.org/10.1046/j.1365-2435.2002.00664.x

Lechenet, M., Dessaint, F., Py, G., Makowski, D., Munier-Jolain, N., 2017. Reducing pesticide use while preserving crop productivity and profitability on arable farms. Nat. Plants 3, 17008. https://doi.org/10.1038/nplants.2017.8 
Leemput, I.A. van de, Dakos, V., Scheffer, M., Nes, E.H. van, 2018. Slow Recovery from Local Disturbances as an Indicator for Loss of Ecosystem Resilience. Ecosystems 21, 141-152. https://doi.org/10.1007/s10021-017-0154-8

Le Féon, V., Burel, F., Chifflet, R., Henry, M., Ricroch, A., Vaissière, B.E., Baudry, J., 2013. Solitary bee abundance and species richness in dynamic agricultural landscapes. Agric. Ecosyst. Environ. $166,94-101$.

Le Féon, V., Schermann-Legionnet, A., Delettre, Y., Aviron, S., Billeter, R., Bugter, R., Hendrickx, F., Burel, F., 2010. Intensification of agriculture, landscape composition and wild bee communities: A large scale study in four European countries. Agric. Ecosyst. Environ. 137, $143-150$.

Lever, J.J., Nes, E.H. van, Scheffer, M., Bascompte, J., 2014. The sudden collapse of pollinator communities. Ecol. Lett. 17, 350-359. https://doi.org/10.1111/ele.12236

Levine, J.M., Adler, P.B., Yelenik, S.G., 2004. A meta-analysis of biotic resistance to exotic plant invasions. Ecol. Lett. 7, 975-989. https://doi.org/10.1111/j.1461-0248.2004.00657.x

Lockwood, J.L., 1977. Fungistatis in soils. Biol. Rev. 52, 1-43. https://doi.org/10.1111/j.1469185X.1977.tb01344.x

Lövei, G.L., Ferrante, M., 2017. A review of the sentinel prey method as a way of quantifying invertebrate predation under field conditions. Insect Sci. 24, 528-542.

Lundberg, J., Moberg, F., 2003. Mobile Link Organisms and Ecosystem Functioning: Implications for Ecosystem Resilience and Management. Ecosystems 6, 0087-0098. https://doi.org/10.1007/s10021-002-0150-4

Maas, B., Tscharntke, T., Saleh, S., Dwi Putra, D., Clough, Y., 2015a. Avian species identity drives predation success in tropical cacao agroforestry. J. Appl. Ecol. 52, 735-743. https://doi.org/10.1111/1365-2664.12409

Macfadyen, S., Craze, P.G., Polaszek, A., van Achterberg, K., Memmott, J., 2011. Parasitoid diversity reduces the variability in pest control services across time on farms. Proc. R. Soc. B Biol. Sci. 278, 3387-3394. https://doi.org/10.1098/rspb.2010.2673

Macfadyen, S., Gibson, R., Polaszek, A., Morris, R.J., Craze, P.G., Planqué, R., Symondson, W.O.C., Memmott, J., 2009. Do differences in food web structure between organic and conventional farms affect the ecosystem service of pest control? Ecol. Lett. 12, 229-238. https://doi.org/10.1111/j.1461-0248.2008.01279.x 
Maiorano, A., Cerrani, I., Fumagalli, D., Donatelli, M., 2014. New biological model to manage the impact of climate warming on maize corn borers. Agron. Sustain. Dev. 34, 609-621. https://doi.org/10.1007/s13593-013-0185-2

Mantyka-Pringle, C.S., Martin, T.G., Rhodes, J.R., 2012. Interactions between climate and habitat loss effects on biodiversity: a systematic review and meta-analysis. Glob. Change Biol. 18, 12391252.

Martin, E.A., Seo, B., Park, C.-R., Reineking, B., Steffan-Dewenter, I., 2016. Scale-dependent effects of landscape composition and configuration on natural enemy diversity, crop herbivory, and yields. Ecol. Appl. 26, 448-462. https://doi.org/10.1890/15-0856.1

Matos, A., Kerkhof, L., Garland, J.L., 2005. Effects of Microbial Community Diversity on the Survival of Pseudomonas aeruginosa in the Wheat Rhizosphere. Microb. Ecol. 49, 257-264. https://doi.org/10.1007/s00248-004-0179-3

Matthiessen, J.N., Kirkegaard, J.A., 2006. Biofumigation and Enhanced Biodegradation: Opportunity and Challenge in Soilborne Pest and Disease Management. Crit. Rev. Plant Sci. 25, 235-265. https://doi.org/10.1080/07352680600611543

Mazzola, M., Brown, J., Izzo, A.D., Cohen, M.F., 2007. Mechanism of Action and Efficacy of Seed Meal-Induced Pathogen Suppression Differ in a Brassicaceae Species and Time-Dependent Manner. Phytopathology 97, 454-460. https://doi.org/10.1094/PHYTO-97-4-0454

McGill, B.J., Enquist, B.J., Weiher, E., Westoby, M., 2006. Rebuilding community ecology from functional traits. Trends Ecol. Evol. 21, 178-185. https://doi.org/10.1016/j.tree.2006.02.002

McKey, D., Rostain, S., Iriarte, J., Glaser, B., Birk, J.J., Holst, I., Renard, D., 2010. Pre-Columbian agricultural landscapes, ecosystem engineers, and self-organized patchiness in Amazonia. Proc. Natl. Acad. Sci. 107, 7823-7828. https://doi.org/10.1073/pnas.0908925107

Menalled, F.D., Costamagna, A.C., Marino, P.C., Landis, D.A., 2003. Temporal variation in the response of parasitoids to agricultural landscape structure. Agric. Ecosyst. Environ. 96, 29-35.

Millennium Ecosystem Assessment, 2005. Ecosystems and human well-being: current state and trends. Millenn. Ecosyst. Assess. Glob. Assess. Rep.

Mocali, S., Landi, S., Curto, G., Dallavalle, E., Infantino, A., Colzi, C., d’Errico, G., Roversi, P.F., D’Avino, L., Lazzeri, L., 2015. Resilience of soil microbial and nematode communities after biofumigant treatment with defatted seed meals. Ind. Crops Prod. 75, 79-90. https://doi.org/10.1016/j.indcrop.2015.04.031 
Mommer, L., Anne Cotton, T. E., Raaijmakers, J. M., Termorshuizen, A. J., van Ruijven, J., Hendriks, M., van Rijssel, S. Q., van de Mortel, J. E., van der Paauw, J. W., Schijlen, E. G. W. M., SmitTiekstra, A. E., Berendse. F., de Kroon, H., Dumbrell, A. J. 2018. Lost in diversity: the interactions between soil-borne fungi, biodiversity and plant productivity. New Phytol. 218: 542-553. https://doi.org/10.1111/nph.15036

Mora, F., 2017. A structural equation modeling approach for formalizing and evaluating ecological integrity in terrestrial ecosystems. Ecol. Inform. 41, 74-90. https://doi.org/10.1016/j.ecoinf.2017.05.002

Morales, C.L., Arbetman, M.P., Cameron, S.A., Aizen, M.A., 2013. Rapid ecological replacement of a native bumble bee by invasive species. Front. Ecol. Environ. 11, 529-534.

Moreira, J.I., Riba-Hernández, P., Lobo, J.A., 2017. Toucans (Ramphastos ambiguus) facilitate resilience against seed dispersal limitation to a large-seeded tree (Virola surinamensis) in a human-modified landscape. Biotropica 49, 502-510. https://doi.org/10.1111/btp.12427

Mori, A.S., 2016. Resilience in the Studies of Biodiversity-Ecosystem Functioning. Trends Ecol. Evol. 31, 87-89. https://doi.org/10.1016/j.tree.2015.12.010

Mori, A.S., Furukawa, T., Sasaki, T., 2013. Response diversity determines the resilience of ecosystems to environmental change. Biol. Rev. 88, 349-364. https://doi.org/10.1111/brv.12004

Naeem, S., 1998. Species Redundancy and Ecosystem Reliability. Conserv. Biol. 12, 39-45. https://doi.org/10.1111/j.1523-1739.1998.96379.x

Naeem, S., Wright, J.P., 2003. Disentangling biodiversity effects on ecosystem functioning: Deriving solutions to a seemingly insurmountable problem. Ecol. Lett. 6, 567-579. https://doi.org/10.1046/j.1461-0248.2003.00471.x

Nash, K.L., Graham, N.A., Jennings, S., Wilson, S.K., Bellwood, D.R., 2016. Herbivore cross-scale redundancy supports response diversity and promotes coral reef resilience. J. Appl. Ecol. 53, 646-655.

Norberg, J., Swaney, D.P., Dushoff, J., Lin, J., Casagrandi, R., Levin, S.A., 2001. Phenotypic diversity and ecosystem functioning in changing environments: A theoretical framework. Proc. Natl. Acad. Sci. 98, 11376-11381. https://doi.org/10.1073/pnas.171315998

Nurdiansyah, F., Denmead, L.H., Clough, Y., Wiegand, K., Tscharntke, T., 2016. Biological control in Indonesian oil palm potentially enhanced by landscape context. Agric. Ecosyst. Environ. 232, 141-149. https://doi.org/10.1016/j.agee.2016.08.006 
Nyffeler, M., Sterling, W.L., Dean, D.A., 1994. How spiders make a living. Environ. Entomol. 23, 13571367. https://doi.org/10.1093/ee/23.6.1357

Öckinger, E., Schweiger, O., Crist, T.O., Debinski, D.M., Krauss, J., Kuussaari, M., Petersen, J.D., Pöyry, J., Settele, J., Summerville, K.S., Bommarco, R., 2010. Life-history traits predict species responses to habitat area and isolation: a cross-continental synthesis. Ecol. Lett. 13, 969-979. https://doi.org/10.1111/j.1461-0248.2010.01487.x

Oerke, E.-C., 2006. Crop losses to pests. J. Agric. Sci. 144, 31-43.

Okuyama, T., Holland, J.N., 2008. Network structural properties mediate the stability of mutualistic communities. Ecol. Lett. 11, 208-216. https://doi.org/10.1111/j.1461-0248.2007.01137.x

Oliver, T.H., Heard, M.S., Isaac, N.J.B., Roy, D.B., Procter, D., Eigenbrod, F., Freckleton, R., Hector, A., Orme, C.D.L., Petchey, O.L., Proença, V., Raffaelli, D., Suttle, K.B., Mace, G.M., Martín-López, B., Woodcock, B.A., Bullock, J.M., 2015a. Biodiversity and Resilience of Ecosystem Functions. Trends Ecol. Evol. 30, 673-684. https://doi.org/10.1016/j.tree.2015.08.009

Oliver, T.H., Isaac, N.J.B., August, T.A., Woodcock, B.A., Roy, D.B., Bullock, J.M., 2015b. Declining resilience of ecosystem functions under biodiversity loss. Nat. Commun. 6, 10122. https://doi.org/10.1038/ncomms10122

Ollerton, J., Winfree, R., Tarrant, S., 2011. How many flowering plants are pollinated by animals? Oikos 120, 321-326.

Orwin, K.H., Wardle, D.A., Greenfield, L.G., 2006. Context-dependent changes in the resistance and resilience of soil microbes to an experimental disturbance for three primary plant chronosequences. Oikos 112, 196-208.

Östman, Ö., Ekbom, B., Bengtsson, J., 2003. Yield increase attributable to aphid predation by groundliving polyphagous natural enemies in spring barley in Sweden. Ecol. Econ. 45, 149-158. https://doi.org/10.1016/S0921-8009(03)00007-7

Partap, U., Ya, T., 2012. The Human Pollinators of Fruit Crops in Maoxian County, Sichuan, China. Mt. Res. Dev. 32, 176-186.

Peralta, G., Frost, C.M., Rand, T.A., Didham, R.K., Tylianakis, J.M., 2014. Complementarity and redundancy of interactions enhance attack rates and spatial stability in host-parasitoid food webs. Ecology 95, 1888-1896. https://doi.org/10.1890/13-1569.1 
Pérez-Piqueres, A., Edel-Hermann, V., Alabouvette, C., Steinberg, C., 2006. Response of soil microbial communities to compost amendments. Soil Biol. Biochem. 38, 460-470. https://doi.org/10.1016/j.soilbio.2005.05.025

Perfecto, I., Vandermeer, J.H., Bautista, G.L., Nuñez, G.I., Greenberg, R., Bichier, P., Langridge, S., 2004. Greater predation in shaded coffee farms: The role of resident neotropical birds. Ecology 85, 2677-2681. https://doi.org/10.1890/03-3145

Peterson, C.A., Eviner, V.T., Gaudin, A.C., 2018. Ways forward for resilience research in agroecosystems. Agric. Syst. 162, 19-27.

Peterson, G., Allen, C.R., Holling, C.S., 1998. Ecological resilience, biodiversity, and scale. Ecosystems $1,6-18$.

Pillar, V.D., Blanco, C.C., Müller, S.C., Sosinski, E.E., Joner, F., Duarte, L.D., 2013. Functional redundancy and stability in plant communities. J. Veg. Sci. 24, 963-974.

Pisa, L.W., Amaral-Rogers, V., Belzunces, L.P., Bonmatin, J.M., Downs, C.A., Goulson, D., Kreutzweiser, D.P., Krupke, C., Liess, M., McField, M., Morrissey, C.A., Noome, D.A., Settele, J., Simon-Delso, N., Stark, J.D., Van der Sluijs, J.P., Van Dyck, H., Wiemers, M., 2015. Effects of neonicotinoids and fipronil on non-target invertebrates. Environ. Sci. Pollut. Res. 22, 68-102. https://doi.org/10.1007/s11356-014-3471-x

Pitts-Singer, T.L., Artz, D.R., Peterson, S.S., Boyle, N.K., Wardell, G.I., 2018. Examination of a Managed Pollinator Strategy for Almond Production Using Apis mellifera (Hymenoptera: Apidae) and Osmia lignaria (Hymenoptera: Megachilidae). Environ. Entomol. 47, 364-377. https://doi.org/10.1093/ee/nvy009

Poisot, T., Mouquet, N., Gravel, D., 2013. Trophic complementarity drives the biodiversity-ecosystem functioning relationship in food webs. Ecol. Lett. 16, 853-861. https://doi.org/10.1111/ele.12118

Porcel, M., Andersson, G.K.S., Pålsson, J., Tasin, M., 2018. Organic management in apple orchards: higher impacts on biological control than on pollination. J. Appl. Ecol. https://doi.org/10.1111/1365-2664.13247

Potts, S.G., Biesmeijer, J.C., Kremen, C., Neumann, P., Schweiger, O., Kunin, W.E., 2010. Global pollinator declines: trends, impacts and drivers. Trends Ecol. Evol. 25, 345-53. 
Potts, S.G., Imperatriz-Fonseca, V., Ngo, H.T., Aizen, M.A., Biesmeijer, J.C., Breeze, T.D., Dicks, L.V., Garibaldi, L.A., Hill, R., Settele, J., Vanbergen, A.J., 2016. Safeguarding pollinators and their values to human well-being. Nature 540, 220-229.

Pywell, R.F., Heard, M.S., Woodcock, B.A., Hinsley, S., Ridding, L., Nowakowski, M., Bullock, J.M., 2015. Wildlife-friendly farming increases crop yield: evidence for ecological intensification. Proc R Soc B 282, 20151740. https://doi.org/10.1098/rspb.2015.1740

Raaijmakers, J.M., Paulitz, T.C., Steinberg, C., Alabouvette, C., Moënne-Loccoz, Y., 2009. The rhizosphere: a playground and battlefield for soilborne pathogens and beneficial microorganisms. Plant Soil 321, 341-361. https://doi.org/10.1007/s11104-008-9568-6

Rader, R., Reilly, J., Bartomeus, I., Winfree, R., 2013. Native bees buffer the negative impact of climate warming on honey bee pollination of watermelon crops. Glob. Change Biol. 19, 31033110.

Rader, R., Bartomeus, I., Garibaldi, L.A., Garrat, M.D.P., Howlett, B., Cunningham, S.A., Mayfield, M.M., Arthur, A.D., Andersson, G.K.S., Bommarco, R., Brittain, C., Carvalheiro, L.G., Chacoff, N.P., Entling, M.H., Foully, B., Freitas, B.M., Gemmill-Herren, B., Ghazoul, J., Griffin, S.R., Gross, C.L., Herbertsson, L., Herzog, F., Hipólito, J., Jaggar, S., Jauker, F., Klein, A.M., Kleijn, D., Krishnan, S., Lemos, C.Q., Lindström, S.A.M., Mandelik, Y., Monteiro, V.M., Nelson, W., Nilsson, L., Pattemore, D.E., de O. Pereira, N., Pisanty, G., Potts, S.G., Reemer, M., Rundlöf, M., Sheffield, C.S., Scheper, J., Schüepp, C., Smith, H.G., Stanley, D.A., Stout, J.C., Szentgyörgyi, H., Taki, H., Vergara, C.H., Viana, B.F., Woyciechowski, M., 2016. Non-bee insects are important contributors to global crop pollination. Proc. Natl. Acad. Sci. 113, 146-151.

Redlich, S., Martin, E.A., Steffan-Dewenter, I., 2018. Landscape-level crop diversity benefits biological pest control. J. Appl. Ecol. https://doi.org/10.1111/1365-2664.13126

Ricketts,T.H., Regetz, J., Steffan-Dewenter, I., Cunningham, S.A., Kremen, C., Bogdanski, A., GemmillHerren, B., Greenleaf, S.S., Klein, A.M., Mayfield, M.M., Morandin, L.A., Ochieng, A., Potts, S.G., Viana, B.F., 2008. Landscape effects on crop pollination services: are there general patterns? Ecol. Lett. 11, 499-515. https://doi.org/10.1111/j.1461-0248.2008.01157.x

Romo, C.M., Tylianakis, J.M., 2013. Elevated temperature and drought interact to reduce parasitoid effectiveness in suppressing hosts. PLoS One 8, e58136.

Roslin, T., Hardwick, B., Novotny, V., Petry, W.K., Andrew, N.R., Asmus, A., Barrio, I.C., Basset, Y., Boesing, A.L., Bonebrake, T.C., Cameron, E.K., Dáttilo, W., Donoso, D.A., Drozd, P., Gray, C.L., 

Hik, D.S., Hill, S.J., Hopkins, T., Huang, S., Koane, B., Laird-Hopkins, B., Laukkanen, L., Lewis, O.T., Milne, S., Mwesige, I., Nakamura, A., Nell, C.S., Nichols, E., Prokurat, A., Sam, K., Schmidt, N.M., Slade, A., Slade, V., Suchanková, A., Teder, T., Van Nouhuys, S., Vandvik, V., Weissflog, A., Zhukovich, V., Slade, E.M., 2017. Latitudinal gradients: Higher predation risk for insect prey at low latitudes and elevations. Science 356, 742-744. https://doi.org/10.1126/science.aaj1631

Rowe, R.C., 1978. Control of Fusarium Crown and Root Rot of Greenhouse Tomatoes by Inhibiting Recolonization of Steam-Disinfested Soil with a Captafol Drench. Phytopathology 68, 1221. https://doi.org/10.1094/Phyto-68-1221

Rundlöf, M., Andersson, G.K.S., Bommarco, R., Fries, I., Hederström, V., Herbertsson, L., Jonsson, O., Klatt, B.K., Pedersen,T.R., Yourstone, J., Smith, H.G., 2015. Seed coating with a neonicotinoid insecticide negatively affects wild bees, Nature, 521, 77-80.

Rusch, A., Bommarco, R., Jonsson, M., Smith, H.G., Ekbom, B., 2013. Flow and stability of natural pest control services depend on complexity and crop rotation at the landscape scale. J. Appl. Ecol. 50, 345-354. https://doi.org/10.1111/1365-2664.12055

Rusch, A., Chaplin-Kramer, R., Gardiner, M.M., Hawro, V., Holland, J., Landis, D., Thies, C., Tscharntke, T., Weisser, W.W., Winqvist, C., Woltz, M., Bommarco, R., 2016. Agricultural landscape simplification reduces natural pest control: A quantitative synthesis. Agric. Ecosyst. Environ. 221, 198-204. https://doi.org/10.1016/j.agee.2016.01.039

Saez, A., Morales, C.L., Garibaldi, L.A., Aizen, M.A., 2017. Invasive bumble bees reduce nectar availability for honey bees by robbing raspberry flower buds. Basic Appl. Ecol. 19, 26-35. https://doi.org/10.1016/j.baae.2017.01.001

Sala, O.E., Chapin, F.S., lii, Armesto, J.J., Berlow, E., Bloomfield, J., Dirzo, R., Huber-Sanwald, E., Huenneke, L.F., Jackson, R.B., Kinzig, A., Leemans, R., Lodge, D.M., Mooney, H.A., Oesterheld, M., Poff, N.L., Sykes, M.T., Walker, B.H., Walker, M., Wall, D.H., 2000. Global Biodiversity Scenarios for the Year 2100. Science 287, 1770-1774. https://doi.org/10.1126/science.287.5459.1770

Sanders, D., Thébault, E., Kehoe, R., Veen, F.J.F. van, 2018. Trophic redundancy reduces vulnerability to extinction cascades. Proc. Natl. Acad. Sci. 115, 2419-2424. https://doi.org/10.1073/pnas.1716825115 
Sasaki, T., Furukawa, T., Iwasaki, Y., Seto, M., Mori, A.S., 2015. Perspectives for ecosystem management based on ecosystem resilience and ecological thresholds against multiple and stochastic disturbances. Ecol. Indic. 57, 395-408.

Scheffer, M., Bascompte, J., Brock, W.A., Brovkin, V., Carpenter, S.R., Dakos, V., Held, H., Nes, E.H. van, Rietkerk, M., Sugihara, G., 2009. Early-warning signals for critical transitions. Nature 461, 53-59. https://doi.org/10.1038/nature08227

Scheffer, M., Carpenter, S.R., Dakos, V., van Nes, E.H., 2015. Generic Indicators of Ecological Resilience: Inferring the Chance of a Critical Transition. Annu. Rev. Ecol. Evol. Syst. 46, 145167. https://doi.org/10.1146/annurev-ecolsys-112414-054242

Schellhorn, N.A., Bianchi, F., Hsu, C.L., 2014. Movement of entomophagous arthropods in agricultural landscapes: links to pest suppression. Annu. Rev. Entomol. 59, 559-581.

Schellhorn, N.A., Gagic, V., Bommarco, R., 2015. Time will tell: resource continuity bolsters ecosystem services. Trends Ecol. Evol. 30, 524-530.

Schlatter, D., Kinkel, L., Thomashow, L., Weller, D., Paulitz, T., 2017. Disease suppressive soils: new insights from the soil microbiome. Phytopathology 107, 1284-1297.

Siegel-Hertz, K., Edel-Hermann, V., Chapelle, E., Terrat, S., Raaijmakers, J.M., Steinberg, C., 2018. Comparative Microbiome Analysis of a Fusarium Wilt Suppressive Soil and a Fusarium Wilt Conducive Soil From the Châteaurenard Region. Front. Microbiol. 9. https://doi.org/10.3389/fmicb.2018.00568

Smolinska, U., Morra, M.J., Knudsen, G.R., James, R.L., 2003. Isothiocyanates Produced by Brassicaceae Species as Inhibitors of Fusarium oxysporum. Plant Dis. 87, 407-412. https://doi.org/10.1094/PDIS.2003.87.4.407

Standish, R.J., Hobbs, R.J., Mayfield, M.M., Bestelmeyer, B.T., Suding, K.N., Battaglia, L.L., Eviner, V., Hawkes, C.V., Temperton, V.M., Cramer, V.A., 2014. Resilience in ecology: abstraction, distraction, or where the action is? Biol. Conserv. 177, 43-51.

Stapel, J.O., Cortesero, A.M., Lewis, W.J., 2000. Disruptive sublethal effects of insecticides on biological control: Altered foraging ability and life span of a parasitoid after feeding on extrafloral nectar of cotton treated with systemic insecticides. Biol. Control 17, 243-249. https://doi.org/10.1006/bcon.1999.0795 
Staudacher, K., Rennstam Rubbmark, O., Birkhofer, K., Malsher, G., Sint, D., Jonsson, M., Traugott, M., 2018. Habitat heterogeneity induces rapid changes in the feeding behaviour of generalist arthropod predators. Funct. Ecol. 32, 809-819. https://doi.org/10.1111/1365-2435.13028

Stavert, J.R., Pattemore, D.E., Bartomeus, I., Gaskett, A.C., Beggs, J.R., 2018. Exotic flies maintain pollination services as native pollinators decline with agricultural expansion. J. Appl. Ecol. 55, 1737-1746. https://doi.org/10.1111/1365-2664.13103

Steffan-Dewenter, I., Münzenberg, U., Bürger, C., Thies, C., Tscharntke, T., 2002. Scale-dependent effects of landscape context on three pollinator guilds. Ecology 83, 1421-1432.

Steffan-Dewenter, I., Schiele, S., 2008. Do resources or natural enemies drive bee population dynamics in fragmented habitats? Ecology 89, 1375-1387.

Steffen, W., Rockström, J., Richardson, K., Lenton, T.M., Folke, C., Liverman, D., Summerhayes, C.P., Barnosky, A.D., Cornell, S.E., Crucifix, M., 2018. Trajectories of the Earth System in the Anthropocene. Proc. Natl. Acad. Sci. 115, 8252-8259.

Sterling, E.J., Filardi, C., Toomey, A., Sigouin, A., Betley, E., Gazit, N., Newell, J., Albert, S., Alvira, D., Bergamini, N., 2017. Biocultural approaches to well-being and sustainability indicators across scales. Nat. Ecol. Evol. 1, 1798.

Stres, B., Philippot, L., Faganeli, J., Tiedje, J.M., 2010. Frequent freeze-thaw cycles yield diminished yet resistant and responsive microbial communities in two temperate soils: a laboratory experiment. FEMS Microbiol. Ecol. 74, 323-335. https://doi.org/10.1111/j.1574$6941.2010 .00951 . x$

Suding, K.N., Lavorel, S., Chapin, F.S., Cornelissen, J.H.C., Díaz, S., Garnier, E., Goldberg, D., Hooper, D.U., Jackson, S.T., Navas, M.-L., 2008. Scaling environmental change through the communitylevel: a trait-based response-and-effect framework for plants. Glob. Change Biol. 14, 11251140. https://doi.org/10.1111/j.1365-2486.2008.01557.x

Tamburini, G., De Simone, S., Sigura, M., Boscutti, F., Marini, L., 2016. Conservation tillage mitigates the negative effect of landscape simplification on biological control. J. Appl. Ecol. 53, 233-241. https://doi.org/10.1111/1365-2664.12544

Termorshuizen, A.J., Jeger, M.J., 2008. Strategies of soilborne plant pathogenic fungi in relation to disease suppression. Fungal Ecol. 1, 108-114. https://doi.org/10.1016/j.funeco.2008.10.006

Termorshuizen, A.J., van Rijn, E., van der Gaag, D.J., Alabouvette, C., Chen, Y., Lagerlöf, J., Malandrakis, A.A., Paplomatas, E.J., Rämert, B., Ryckeboer, J., Steinberg, C., Zmora-Nahum, S., 
2006. Suppressiveness of 18 composts against 7 pathosystems: Variability in pathogen response. Soil Biol. Biochem. 38, 2461-2477. https://doi.org/10.1016/j.soilbio.2006.03.002

Thébault, E., Fontaine, C., 2010. Stability of Ecological Communities and the Architecture of Mutualistic and Trophic Networks. Science 329, 853-856. https://doi.org/10.1126/science.1188321

Thibaut, L.M., Connolly, S.R., 2013. Understanding diversity-stability relationships: Towards a unified model of portfolio effects. Ecol. Lett. 16, 140-150. https://doi.org/10.1111/ele.12019

Thies, C., Haenke, S., Scherber, C., Bengtsson, J., Bommarco, R., Clement, L.W., Ceryngier, P., Dennis, C., Emmerson, M., Gagic, V., Hawro, V., Liira, J., Weisser, W.W., Winqvist, C., Tscharntke, T., 2011. The relationship between agricultural intensification and biological control: experimental tests across Europe. Ecol Appl 21, 2187-2196. https://doi.org/10.1890/100929.1

Thies, C., Tscharntke, T., 1999. Landscape structure and biological control in agroecosystems. Science $285,893-895$.

Thomson, L.J., Macfadyen, S., Hoffmann, A.A., 2010. Predicting the effects of climate change on natural enemies of agricultural pests. Biol. Control 52, 296-306. https://doi.org/10.1016/J.BIOCONTROL.2009.01.022

Thorbek, P., Bilde, T., 2004. Reduced numbers of generalist arthropod predators after crop management. J. Appl. Ecol. 41, 526-538. https://doi.org/10.1111/j.0021-8901.2004.00913.x

Thrush, S.F., Hewitt, J.E., Dayton, P.K., Coco, G., Lohrer, A.M., Norkko, A., Norkko, J., Chiantore, M., 2009. Forecasting the limits of resilience: integrating empirical research with theory. Proc. R. Soc. Lond. B Biol. Sci. rspb20090661. https://doi.org/10.1098/rspb.2009.0661

Trivedi, P., Delgado-Baquerizo, M., Trivedi, C., Hamonts, K., Anderson, I.C., Singh, B.K., 2017. Keystone microbial taxa regulate the invasion of a fungal pathogen in agro-ecosystems. Soil Biol. Biochem. 111, 10-14. https://doi.org/10.1016/j.soilbio.2017.03.013

Tscharntke, T., Karp, D.S., Chaplin-Kramer, R., Batáry, P., DeClerck, F., Gratton, C., Hunt, L., Ives, A., Jonsson, M., Larsen, A., Martin, E.A., Martínez-Salinas, A., Meehan, T.D., O’Rourke, M., Poveda, K., Rosenheim, J.A., Rusch, A., Schellhorn, N., Wanger, T.C., Wratten, S., Zhang, W., 2016. When natural habitat fails to enhance biological pest control - Five hypotheses. Biol. Conserv. 204, Part B, 449-458. https://doi.org/10.1016/j.biocon.2016.10.001 
Tscharntke, T., Bommarco, R., Clough, Y., Crist, T.O., Kleijn, D., Rand, T.A., Tylianakis, J.M., van Nouhuys, S., Vidal, S., 2008a. Reprint of "Conservation biological control and enemy diversity on a landscape scale" [Biol. Control 43 (2007) 294-309]. Biol. Control 45, 238-253.

Tscharntke, T., Sekercioglu, C.H., Dietsch, T. V., Sodhi, N.S., Hoehn, P., Tylianakis, J.M., 2008b. Landscape constraints on functional diversity of birds and insects in tropical agroecosystems. Ecology 89, 944-951. https://doi.org/10.1890/07-0455.1

Tscharntke, T., Tylianakis, J.M., Rand, T.A., Didham, R.K., Fahrig, L., Batary, P., Bengtsson, J., Clough, Y., Crist, T.O., Dormann, C.F., others, 2012. Landscape moderation of biodiversity patterns and processes-eight hypotheses. Biol. Rev. 87, 661-685.

Tuck, S.L., Winqvist, C., Mota, F., Ahnström, J., Turnbull, L.A., Bengtsson, J., 2014. Land-use intensity and the effects of organic farming on biodiversity: A hierarchical meta-analysis. J. Appl. Ecol. https://doi.org/10.1111/1365-2664.12219

Tylianakis, J.M., Morris, R.J., 2017. Ecological Networks Across Environmental Gradients. Annu. Rev. Ecol. Evol. Syst. 48, 25-48. https://doi.org/10.1146/annurev-ecolsys-110316-022821

Tylianakis, J.M., Didham, R.K., Bascompte, J., Wardle, D.A., 2008. Global change and species interactions in terrestrial ecosystems. Ecol. Lett. 11, 1351-1363. https://doi.org/10.1111/j.1461-0248.2008.01250.x

Tylianakis, J.M., Tscharntke, T., Klein, A.M., 2006. Diversity, ecosystem function, and stability of parasitoid-host interactions across a tropical habitat gradient. Ecology 87, 3047-3057. https://doi.org/10.1890/0012-9658(2006)87[3047:DEFASO]2.0.CO;2

Valone, T.J., Barber, N.A., 2008. An Empirical Evaluation of the Insurance Hypothesis in DiversityStability Models. Ecology 89, 522-531. https://doi.org/10.1890/07-0153.1

van Elsas, J.D., Chiurazzi, M., Mallon, C.A., Elhottova, D., Kristufek, V., Salles, J.F., 2012. Microbial diversity determines the invasion of soil by a bacterial pathogen. Proc. Natl. Acad. Sci. 109, 1159-1164. https://doi.org/10.1073/pnas.1109326109

van Vliet, J., de Groot, H.L.F., Rietveld, P., Verburg, P.H., 2015. Manifestations and underlying drivers of agricultural land use change in Europe. Landsc. Urban Plan. 133, 24-36. https://doi.org/10.1016/j.landurbplan.2014.09.001

Vandermeer, J., 2011. The inevitability of surprise in agroecosystems. Ecol. Complex., Special Section: Complexity of Coupled Human and Natural Systems 8, 377-382. https://doi.org/10.1016/j.ecocom.2011.10.001 
Vasseur, C., Joannon, A., Aviron, S., Burel, F., Meynard, J.-M., Baudry, J., 2013. The cropping systems mosaic: How does the hidden heterogeneity of agricultural landscapes drive arthropod populations? Agric. Ecosyst. Environ. 166, 3-14. https://doi.org/10.1016/j.agee.2012.08.013

Veraart, A.J., Faassen, E.J., Dakos, V., Nes, E.H. van, Lürling, M., Scheffer, M., 2012. Recovery rates reflect distance to a tipping point in a living system. Nature 481, 357-359. https://doi.org/10.1038/nature10723

Walker, B., Holling, C.S., Carpenter, S., Kinzig, A., 2004. Resilience, Adaptability and Transformability in Social-ecological Systems. Ecol. Soc. 9. https://doi.org/10.5751/ES-00650-090205

Wang, Q., Ma, Y., Wang, G., Gu, Z., Sun, D., An, X., Chang, Z., 2014. Integration of biofumigation with antagonistic microorganism can control Phytophthora blight of pepper plants by regulating soil bacterial community structure. Eur. J. Soil Biol. 61, 58-67. https://doi.org/10.1016/j.ejsobi.2013.12.004

Weerakoon, D.M.N., Reardon, C.L., Paulitz, T.C., Izzo, A.D., Mazzola, M., 2012. Long-term suppression of Pythium abappressorium induced by Brassica juncea seed meal amendment is biologically mediated. Soil Biol. Biochem. 51, 44-52. https://doi.org/10.1016/j.soilbio.2012.03.027

Wei, F., Passey, T., Xu, X., 2016. Amplicon-based metabarcoding reveals temporal response of soil microbial community to fumigation-derived products. Appl. Soil Ecol. 103, 83-92. https://doi.org/10.1016/j.apsoil.2016.03.009

Wei, Z., Yang, T., Friman, V.-P., Xu, Y., Shen, Q., Jousset, A., 2015. Trophic network architecture of root-associated bacterial communities determines pathogen invasion and plant health. Nat. Commun. 6. https://doi.org/10.1038/ncomms9413

Weibull, A.C., Östman, Ö., Granqvist, Å., 2003. Species richness in agroecosystems: The effect of landscape, habitat and farm management. Biodivers. Conserv. 12, 1335-1355. https://doi.org/10.1023/A:1023617117780

Weise, H., Auge, H., Baessler, C., Baerlund, I., Bennett, E.M., Berger, U., Bohn, F., Bonn, A., Borchardt, D., Brand, F., Chatzinotas, A., Corstanje, R., Laender, F.D., Dietrich, P., Dunker, S., Durka, W., Fazey, I., Groeneveld, J., Guilbaud, C.S.E., Harms, H., Harpole, S., Harris, J.A., Jax, K., Jeltsch, F., Johst, K., Joshi, J., Klotz, S., Kuehn, I., Kuhlicke, C., Mueller, B., Radchuk, V., Reuter, H., Rinke, K., Schmitt-Jansen, M., Seppelt, R., Singer, A.S., Standish, R.J., Thulke, H.-H., Tietjen, B., Weitere, M., Wirth, C., Wolf, C., Grimm, V., 2019. Resilience trinity: safeguarding 
ecosystem services across three different time horizons and decision contexts. bioRxiv 549873. https://doi.org/10.1101/549873

Weller, D.M., Raaijmakers, J.M., Gardener, B.B.M., Thomashow, L.S., 2002. Microbial populations responsible for specific soil suppressiveness to plant pathogens. Annu. Rev. Phytopathol. 40, 309-348. https://doi.org/10.1146/annurev.phyto.40.030402.110010

Wheeler, T., Braun, J. von, 2013. Climate Change Impacts on Global Food Security. Science 341, 508513. https://doi.org/10.1126/science.1239402

Williams, N.M., Ward, K.L., Pope, N., Isaacs, R., Wilson, J., May, E.A., Ellis, J., Daniels, J., Pence, A., Ullmann, K., Peters, J., 2015. Native wildflower plantings support wild bee abundance and diversity in agricultural landscapes across the United States. Ecol. Appl. 25, 2119-2131.

Williams, N.M., Crone, E.E., T’ai, H.R., Minckley, R.L., Packer, L., Potts, S.G., 2010. Ecological and lifehistory traits predict bee species responses to environmental disturbances. Biol. Conserv. 143, 2280-2291. https://doi.org/10.1016/j.biocon.2010.03.024

Williams, P.H., Osborne, J.L., 2009. Bumblebee vulnerability and conservation world-wide. Apidologie 40, 367-87.

With, K.A., Pavuk, D.M., Worchuck, J.L., Oates, R.K., Fisher, J.L., 2002. Threshold Effects of Landscape Structure on Biological Control in Agroecosystems. Ecol. Appl. 12, 52-65. https://doi.org/10.1890/1051-0761.

Woodcock, B.A., Isaac, N.J., Bullock, J.M., Roy, D.B., Garthwaite, D.G., Crowe, A., Pywell, R.F., 2016. Impacts of neonicotinoid use on long-term population changes in wild bees in England. Nat. Commun. 7, 12459.

Woodcock, B.A., Redhead, J., Vanbergen, A.J., 2010. Impact of habitat type and landscape structure on biomass, species richness and functional diversity of ground beetles. Agric Ecosyst Env. $139,181-186$.

Yachi, S., Loreau, M., 1999. Biodiversity and ecosystem productivity in a fluctuating environment: the insurance hypothesis. Proc. Natl. Acad. Sci. 96, 1463-1468.

Yohalem, D., Passey, T., 2011. Amendment of soils with fresh and post-extraction lavender (Lavandula angustifolia) and lavandin (Lavandulaxintermedia) reduce inoculum of Verticillium dahliae and inhibit wilt in strawberry. Appl. Soil Ecol. 49, 187-196. https://doi.org/10.1016/j.apsoil.2011.05.006 
Yulianti, T., Sivasithamparam, K., Turner, D.W., 2007. Saprophytic and pathogenic behaviour of R. solani AG2-1 (ZG-5) in a soil amended with Diplotaxis tenuifolia or Brassica nigra manures and incubated at different temperatures and soil water content. Plant Soil 294, 277-289. https://doi.org/10.1007/s11104-007-9254-0

\section{Table and figure legends}

Table 1. Indicators of agroecosystem function resilience and theoretical and empirical evidence for their use. In green: evidence from biodiversity-driven functions in agroecosystems. In black: evidence for biodiversity-driven functions from other systems.

Fig. 1. Schematic representation of different concepts of resilience. (a) Persistence as the ability to continue function provision under high disturbance levels. The system represented by the dashed red line is less resilient than the system shown by the solid blue line. The persistence domain (grey) indicates the amount of function necessary to continue service provision. (b) Engineering resilience as the ability of a system to bounce back after disturbance at $t_{0}$. The system represented by the solid blue line is able to recover faster (returning to the persistence domain (grey) at $t_{1}$ ), than the system shown by the dashed red line (returning to the persistence domain at $t_{2}$ ). (c) Ecological resilience as the strength of disturbance a system can absorb before it moves to an alternate state. Illustrated are four different resilience regimes ranging from high (blue) to low resilience (red). The difference in resilience is a consequence of (1) the topography of the domain and (2) the precariousness of the system, i.e. its closeness to the tipping point to an alternate state prior to the disturbance event. The 
strength of the disturbance required to push the system over the tipping point to an alternate state increases with resilience of the system, indicated by the red arrows. Adapted with modification from Döring et al. (2013).

Fig. 2. Types of disturbances characteristic of agroecosystems that affect biodiversity-driven functions across spatial (on the $y$-axis), temporal and organizational scales. Disturbances listed here refer particularly to drivers of global environmental change including land use change, climate change and biotic invasions. Regularly recurring, anthropogenic 'pulses' (recurring acute disturbances) are key features of most agroecosystems that may intensify or decrease under agricultural land use change. They take place at the same time as other, non-recurring pulses (sporadic acute disturbances such as extreme climate events) and 'presses' (chronic disturbances), which represent gradual changes taking place over long periods of time or large spatial scales. Local, field-level disturbances (crop rotation, introduction of new crops \& varieties, supplementation of beneficial species including pollinators and antagonists, pesticide application, harvesting, changes in field size) frequently upscale to impact biodiversity-driven functions at the landscape level.

Fig. 3. Breaking down the meaning of an operational framework to measure resilience of agroecosystem functions to environmental change. a) Biodiversity-driven agroecosystem functions are exemplified by biological pest control taking place in different crop fields of agricultural landscapes. At a hypothetical reference time $t_{0}$, crop fields and landscapes are under extensive cultivation (low-intensity cropping practices, small fields, high amounts of non-crop habitat around fields). Between $t_{0}$ and $t_{1}$, some fields and landscapes undergo varying degrees of intensification (the disturbance D1): fields are enlarged, habitat is cleared, crop management becomes intensive. This leads to a gradient in land use intensity between fields and/or between landscapes. In a space-fortime substitution, pest control in 'undisturbed' landscapes becomes a dynamic reference of the pest 
control that could have been provided in 'disturbed' landscapes if intensification had not occurred.

b) One aim of an operational resilience framework is to predict pest control resilience to D1 in 'as yet undisturbed' areas, by extrapolating its observed resilience to D1 in disturbed areas. Specifically, we may ask if the function persisted after D1 (stayed in or recovered to a socially acceptable persistence domain), or underwent a regime shift to no or insufficient function. Critically, the temporal resolution of measurements determines their richness of interpretation. Short-term or one-time assessments of persistence, as most often performed, give no indication of potential future recovery. However, because D1 has happened and the function's response can be assessed, these measures are key opportunities to test the performance of indicators of function resilience.

Fig. 4. In addition to predicting a function's resilience in response to disturbance D1 (see Fig. 3), a second aim of an operational resilience framework is to understand how D1 affects the function's resilience to further, potentially different disturbances (D2). We highlight four scenarios: in i) and ii), resilience to D1 was high, but in ii) the function's buffering capacity (resistance, recovery) for further disturbance has been affected. In iii) and iv), resilience to D1 was low and in iv), D1 further affected the function's resilience to further disturbance. Because D2 is a future, yet unrealized disturbance, the only way to assess resilience to such future disturbance is via indicators with known validity and interpretation. Blue lines: dynamic undisturbed reference system; red dashes: dynamic disturbed system. 
2142 Table 1. Indicators of agroecosystem function resilience and theoretical and empirical evidence for their use. In green: evidence from biodiversity-driven

2143 functions in agroecosystems. Evidence for biodiversity-driven functions from other systems is shown in black.

\begin{tabular}{|c|c|c|c|c|c|}
\hline \multirow[b]{2}{*}{ Indicator } & \multirow[b]{2}{*}{ Definition } & \multirow{2}{*}{$\begin{array}{l}\text { How does the indicator affect resilience } \\
\text { of functioning? }\end{array}$} & \multirow{2}{*}{$\begin{array}{l}\text { Resilience property } \\
\text { affected }\end{array}$} & \multicolumn{2}{|c|}{ Evidence for a link between indicator and function resilience } \\
\hline & & & & Models & Data \\
\hline \multicolumn{6}{|c|}{ Indicators of function resilience based on measures of biodiversity } \\
\hline $\begin{array}{l}\text { Species richness or } \\
\text { diversity (Elmqvist et } \\
\text { al., 2003; Peterson et } \\
\text { al., 1998) }\end{array}$ & $\begin{array}{l}\text { Number or diversity of } \\
\text { species in a community }\end{array}$ & $\begin{array}{l}\text { 'Portfolio effect' contributing to the } \\
\text { insurance value of biodiversity. But, } \\
\text { species-rich systems may still be very } \\
\text { vulnerable to disturbance, and ignores the } \\
\text { fact that loss of species if non-random }\end{array}$ & $\begin{array}{l}\text { Resistance or recovery } \\
\text { (cf. mechanisms of } \\
\text { response diversity) }\end{array}$ & $\begin{array}{l}\text { High species richness leads to } \\
\text { persistence of functions by } \\
\text { buffering disturbances (e.g. } \\
\text { (Hooper et al., 2005; Yachi and } \\
\text { Loreau, 1999) }\end{array}$ & $\begin{array}{l}\text { Found for some but not all disturbances (e.g. not } \\
\text { drought, warming or high environmental } \\
\text { variance) (Balvanera et al., 2006) (various } \\
\text { functions); Isbell et al., } 2015 \text { (plant productivity) }\end{array}$ \\
\hline $\begin{array}{l}\text { Presence of key } \\
\text { species or functional } \\
\text { groups (Elmqvist et al., } \\
\text { 2003; Folke et al., } \\
\text { 2004; Gagic et al., } \\
\text { 2015) } \\
\end{array}$ & $\begin{array}{l}\text { Presence of species or } \\
\text { functional groups } \\
\text { providing the majority } \\
\text { of a function }\end{array}$ & $\begin{array}{l}\text { Presence of key groups is necessary to } \\
\text { provide function; their loss leads to loss of } \\
\text { function }\end{array}$ & $\begin{array}{l}\text { Resistance; regime shift } \\
\text { to 'no function' if key } \\
\text { functional group is } \\
\text { removed }\end{array}$ & $\begin{array}{l}\text { The consequences of the number } \\
\text { of species removed from a } \\
\text { system depends on the function } \\
\text { those species perform in the } \\
\text { system (Dunne et al., 2002) }\end{array}$ & $\begin{array}{l}\text { Maas et al., } 2015 \text { (pest control); Caves et al., } \\
2013 \text { (seed dispersal); Anderson et al., 2011; } \\
\text { Garibaldi et al., } 2009 \text { (pollination); Weller et al., } \\
2002 \text { (soil disease control) }\end{array}$ \\
\hline $\begin{array}{l}\text { Functional diversity } \\
\text { (Elmqvist et al., 2003; } \\
\text { Folke et al., 2004; Gagic } \\
\text { et al., 2015) }\end{array}$ & $\begin{array}{l}\text { Diversity of functions } \\
\text { performed by } \\
\text { organisms in the } \\
\text { community }\end{array}$ & $\begin{array}{l}\text { May lead to presence of key groups (see } \\
\text { above) through sampling effects; may } \\
\text { enhance function continuity in } \\
\text { spatiotemporal crop mosaics; implies high } \\
\text { niche occupation, which should buffer } \\
\text { against invasion and altered interactions }\end{array}$ & $\begin{array}{l}\text { Resistance of } \\
\text { functioning due to } \\
\text { continued performance } \\
\text { in different crops / times } \\
\text { or due to competition } \\
\text { for niche space }\end{array}$ & & $\begin{array}{l}\text { Eisenhauer et al., 2013; Elsas et al., } 2012 \text { (soil } \\
\text { disease control); Fargione and Tilman, } 2005 \\
\text { (plant productivity) }\end{array}$ \\
\hline $\begin{array}{l}\text { Functional redundancy } \\
\text { (Biggs et al., 2015; De } \\
\text { Bello et al., 2009; Folke } \\
\text { et al., 2004; Naeem, } \\
\text { 1998; Peterson et al., } \\
\text { 1998) }\end{array}$ & $\begin{array}{l}\text { Number of species } \\
\text { performing the same } \\
\text { function; the fraction of } \\
\text { species diversity not } \\
\text { expressed by functional } \\
\text { diversity }\end{array}$ & $\begin{array}{l}\text { When combined with response diversity } \\
\text { within functional groups (see below), } \\
\text { functional redundancy leads to increased } \\
\text { function resilience through species } \\
\text { complementarity }\end{array}$ & $\begin{array}{l}\text { Resistance or recovery } \\
\text { (cf. mechanisms of } \\
\text { response diversity) }\end{array}$ & $\begin{array}{l}\text { Functional redundancy leads to } \\
\text { function resilience (Naeem 1998) } \\
\text { and decreases extinction risk of } \\
\text { functional groups (Fonseca \& } \\
\text { Ganade 2001) }\end{array}$ & $\begin{array}{l}\text { Hallett et al., } 2017 \text { (pollination); Joner et al., } \\
2011 \text { find effects on community but not function } \\
\text { resilience (plant productivity); Sanders et al., } \\
2018 \text { (pest control); Griffiths \& Philippot } 2013 \\
\text { (soil functions) }\end{array}$ \\
\hline $\begin{array}{l}\text { Response diversity } \\
\text { (Biggs et al., 2015; } \\
\text { Elmqvist et al., 2003; } \\
\text { Mori et al., 2013; Oliver } \\
\text { et al., 2015a) }\end{array}$ & $\begin{array}{l}\text { Different species (or } \\
\text { individuals within } \\
\text { species) contributing to } \\
\text { the same function } \\
\text { respond differently to } \\
\text { disturbance }\end{array}$ & $\begin{array}{l}\text { Species or individuals performing the } \\
\text { same function but responding differently } \\
\text { to disturbance compensate for each other } \\
\text { under a given disturbance through } \\
\text { functional compensation and } \\
\text { spatiotemporal complementarity }\end{array}$ & $\begin{array}{l}\text { Resistance or recovery } \\
\text { of function due to } \\
\text { performance of species } \\
\text { less or not affected by } \\
\text { the disturbance, and/or } \\
\text { able to adapt and } \\
\text { recover from the } \\
\text { disturbance }\end{array}$ & $\begin{array}{l}\text { Norberg et al., } 2001 \text { show higher } \\
\text { resistance of functioning under } \\
\text { disturbance when response } \\
\text { diversity is high; other work also } \\
\text { points in this direction (reviewed } \\
\text { by Hooper et al. 2005) }\end{array}$ & $\begin{array}{l}\text { Cariveau et al., } 2013 \text { find no link with } \\
\text { persistence of pollination under land use } \\
\text { change, but Rader et al., } 2013 \text { and Stavert et al., } \\
2018 \text { find buffering under climate and land use } \\
\text { change respectively (pollination); Farwig et al., } \\
\text { 2017; González-Varo et al., 2017; Moreira et al., } \\
\text { 2017 (seed dispersal) }\end{array}$ \\
\hline $\begin{array}{l}\text { Cross-scale resilience } \\
\text { (Allen et al., 2014; } \\
\text { Biggs et al., 2015; }\end{array}$ & $\begin{array}{l}\text { Species or functional } \\
\text { groups respond to } \\
\text { disturbance at different }\end{array}$ & $\begin{array}{l}\text { Risk-spreading across scales similarly to } \\
\text { response diversity; due to nestedness of } \\
\text { scales, species can be recruited from e.g. }\end{array}$ & $\begin{array}{l}\text { Resistance due to } \\
\text { species unaffected by } \\
\text { the scale of disturbance. }\end{array}$ & & $\begin{array}{l}\text { Jonsson et al., } 2015 \text { find evidence that pest } \\
\text { control in crops is less affected by local } \\
\text { disturbance when the surrounding landscape is }\end{array}$ \\
\hline
\end{tabular}




\begin{tabular}{|c|c|c|c|c|c|}
\hline $\begin{array}{l}\text { Elmqvist et al., 2003; } \\
\text { Peterson et al., 1998) }\end{array}$ & $\begin{array}{l}\text { spatial or temporal } \\
\text { scales }\end{array}$ & $\begin{array}{l}\text { regional pools to perform functions at the } \\
\text { landscape or local scales }\end{array}$ & $\begin{array}{l}\text { Recovery through } \\
\text { recruitment of species at } \\
\text { an unaffected scale }\end{array}$ & & $\begin{array}{l}\text { complex ('intermediate landscape hypothesis') } \\
\text { (pest control); Nash et al., } 2016 \text { (coral reefs) }\end{array}$ \\
\hline $\begin{array}{l}\text { Negative co-variation } \\
\text { (Elmqvist et al., 2003) }\end{array}$ & $\begin{array}{l}\text { The abundance of pairs } \\
\text { of species with similar } \\
\text { effect on function } \\
\text { tends to be negatively } \\
\text { correlated across } \\
\text { disturbance gradients }\end{array}$ & $\begin{array}{l}\text { Arises through competition in the same } \\
\text { functional group (density compensation) } \\
\text { or differing responses to disturbance. } \\
\text { Similarly to response diversity, leads to } \\
\text { species with similar function replacing } \\
\text { each other under disturbance }\end{array}$ & $\begin{array}{l}\text { Resistance of function } \\
\text { due to performance of } \\
\text { competitors or species } \\
\text { with opposing response } \\
\text { to disturbance }\end{array}$ & $\begin{array}{l}\text { In theory leads to higher function } \\
\text { persistence similarly to response } \\
\text { diversity and is associated with } \\
\text { the statistical portfolio effect of } \\
\text { diversity (Hooper et al., 2005) }\end{array}$ & $\begin{array}{l}\text { Found not to occur often in real communities } \\
\text { and thus untested empirically (Houlahan et al., } \\
\text { 2007; Karp et al., 2011; Valone and Barber, } \\
\text { 2008) }\end{array}$ \\
\hline $\begin{array}{l}\text { Relationship between } \\
\text { effect and response } \\
\text { traits (Díaz et al., 2013; } \\
\text { Lavorel and Garnier, } \\
\text { 2002; Oliver et al., } \\
\text { 2015a; Suding et al., } \\
\text { 2008) }\end{array}$ & $\begin{array}{l}\text { Degree to which effects } \\
\text { of species on function } \\
\text { (their effect traits) are } \\
\text { correlated with the } \\
\text { responses of species to } \\
\text { disturbance (their } \\
\text { response traits) }\end{array}$ & $\begin{array}{l}\text { Correlation between effect and response } \\
\text { traits implies high risk of loss of function if } \\
\text { a response group is removed. Conversely, } \\
\text { if traits are unrelated, function } \\
\text { persistence is decoupled from the } \\
\text { response of single groups to disturbance }\end{array}$ & $\begin{array}{l}\text { Resistance of } \\
\text { functioning through } \\
\text { maintenance of effect } \\
\text { traits across different } \\
\text { levels or types of } \\
\text { disturbance }\end{array}$ & $\begin{array}{l}\text { Díaz et al., } 2013 \text { assess the } \\
\text { theoretical risk of loss of function } \\
\text { due to trait correlation in } 5 \text { case } \\
\text { studies (decomposition, } \\
\text { bushmeat harvest rate, seed } \\
\text { dispersal) }\end{array}$ & $\begin{array}{l}\text { Larsen et al., } 2005 \text { show unexpectedly large } \\
\text { consequences for function persistence of non- } \\
\text { random species loss in relation to their function } \\
\text { (pollination, dung burial) }\end{array}$ \\
\hline $\begin{array}{l}\text { Presence, redundancy } \\
\text { and response diversity } \\
\text { of biological legacies } \\
\text { and/or mobile link } \\
\text { organisms (Elmqvist et } \\
\text { al., 2003; Folke et al., } \\
\text { 2004; Lundberg and } \\
\text { Moberg, 2003) }\end{array}$ & $\begin{array}{l}\text { Biological legacies } \\
\text { remain in the system } \\
\text { after disturbance and } \\
\text { provide sources of } \\
\text { regrowth (e.g. seed } \\
\text { bank, eggs in diapause). } \\
\text { Mobile links are able to } \\
\text { recolonize patches } \\
\text { after a disturbance }\end{array}$ & $\begin{array}{l}\text { 1) Abundance, survival and growth rate of } \\
\text { biological legacies and mobile links; } 2 \text { ) } \\
\text { their support by e.g. undisturbed areas in } \\
\text { the surrounding landscape; and 3) the } \\
\text { accessibility of disturbed patches for } \\
\text { mobile link organisms (i.e. their dispersal } \\
\text { abilities), determine the speed at which } \\
\text { these species can recolonize and provide } \\
\text { functions in disturbed patches }\end{array}$ & $\begin{array}{l}\text { Recovery of function } \\
\text { after disturbance } \\
\text { through renewal and } \\
\text { reorganization }\end{array}$ & & $\begin{array}{l}\text { Seed dispersal resilience is enhanced by mobile } \\
\text { link birds and by biological legacies (isolated } \\
\text { trees and forest patches), but not by bird } \\
\text { response diversity and functional redundancy } \\
\text { (García et al., 2013) (seed dispersal) }\end{array}$ \\
\hline $\begin{array}{l}\text { Network structure and } \\
\text { interactions (Biggs et } \\
\text { al., 2015; Folke et al., } \\
\text { 2004; Tylianakis and } \\
\text { Morris, 2017) }\end{array}$ & $\begin{array}{l}\text { Strength, number and } \\
\text { structure of } \\
\text { interactions between } \\
\text { species of a community }\end{array}$ & $\begin{array}{l}\text { Function resilience should increase with } \\
\text { resource use complementarity and/or } \\
\text { nestedness or modularity of a network, } \\
\text { due to disturbances only affecting } \\
\text { (modifying or removing) a subset of } \\
\text { existing interactions; network } \\
\text { connectedness however is not necessarily } \\
\text { positive for resilience of associated } \\
\text { functions }\end{array}$ & $\begin{array}{l}\text { Resistance and recovery } \\
\text { take place through } \\
\text { buffering by remaining } \\
\text { network links after } \\
\text { disturbance and through } \\
\text { formation of new links, } \\
\text { respectively }\end{array}$ & $\begin{array}{l}\text { Network complementarity } \\
\text { affects functioning under species } \\
\text { loss (Poisot et al., 2013); } \\
\text { nestedness improves network } \\
\text { recovery (Okuyama and Holland, } \\
\text { 2008; Thébault and Fontaine, } \\
\text { 2010); connectance, nestedness } \\
\text { affect proneness to sudden } \\
\text { collapse of pollinators (Lever et } \\
\text { al., 2014) }\end{array}$ & $\begin{array}{l}\text { Peralta et al., } 2014 \text { show network } \\
\text { complementarity enhances parasitism and } \\
\text { decreases its spatial variability, but no test of } \\
\text { persistence under disturbance; apparent } \\
\text { competition shapes response to change of host- } \\
\text { parasitoid networks and parasitism rates (Frost } \\
\text { et al., 2016) (pest control) }\end{array}$ \\
\hline \multicolumn{6}{|c|}{ Other indicators of function resilience } \\
\hline $\begin{array}{l}\text { Recovery rate (Scheffer } \\
\text { et al., 2015) }\end{array}$ & $\begin{array}{l}\text { Functions recover more } \\
\text { and more slowly after } \\
\text { disturbance }\end{array}$ & $\begin{array}{l}\text { 'Critical Slowing Down' of recovery rates } \\
\text { (i.e. engineering resilience) after small } \\
\text { disturbance is an early warning signal of } \\
\text { proximity to a tipping point (i.e. of low } \\
\text { ecological resilience) }\end{array}$ & $\begin{array}{l}\text { Distance to tipping point } \\
\text { or regime shift }\end{array}$ & $\begin{array}{l}\text { Cellular automata show that } \\
\text { slowing recovery rates indicate } \\
\text { proximity to thresholds for plants } \\
\text { in semi-arid systems (Bailey et al. } \\
\text { 2010; Dakos et al. 2011) }\end{array}$ & $\begin{array}{l}\text { Veraart et al. } 2012 \text { show slowing recovery rates } \\
\text { are a robust indicator of tipping point proximity } \\
\text { (cyanobacteria); Dai et al. } 2013 \text { show 'recovery } \\
\text { length' (the distance of recovery for spatially } \\
\text { connected populations) increases with tipping } \\
\text { point proximity (yeast populations) }\end{array}$ \\
\hline $\begin{array}{l}\text { Spatial or temporal } \\
\text { autocorrelation } \\
\text { (Scheffer et al., 2015) } \\
\end{array}$ & $\begin{array}{l}\text { System state variables } \\
\text { become more similar to }\end{array}$ & $\begin{array}{l}\text { Increasing autocorrelation is an early- } \\
\text { warning signal of proximity to a tipping } \\
\text { point }\end{array}$ & $\begin{array}{l}\text { Distance to tipping point } \\
\text { or regime shift }\end{array}$ & $\begin{array}{l}\text { Autocorrelation does not always } \\
\text { increase near a critical transition } \\
\text { (Dakos et al. 2015) and is }\end{array}$ & $\begin{array}{l}\text { Good indicator of critical transition in some } \\
\text { systems (e.g. Veraart et al. 2012) (yeast }\end{array}$ \\
\hline
\end{tabular}




\begin{tabular}{|c|c|c|c|c|c|}
\hline & $\begin{array}{l}\text { each other in space } \\
\text { and/or time }\end{array}$ & & & $\begin{array}{l}\text { affected by spatially } \\
\text { heterogeneous stressors (Génin } \\
\text { et al. 2018) }\end{array}$ & $\begin{array}{l}\text { populations) but not others (e.g. Bestelmeyer et } \\
\text { al. 2013) (plant communities) }\end{array}$ \\
\hline $\begin{array}{l}\text { Spatial or temporal } \\
\text { variance (Carpenter } \\
\text { and Brock, 2006; } \\
\text { Thrush et al., 2009) } \\
\end{array}$ & $\begin{array}{l}\text { The variability of } \\
\text { functioning over time } \\
\text { or space }\end{array}$ & $\begin{array}{l}\text { Increase in function variance is an early- } \\
\text { warning signal of proximity to a tipping } \\
\text { point }\end{array}$ & $\begin{array}{l}\text { Distance to tipping point } \\
\text { or regime shift }\end{array}$ & $\begin{array}{l}\text { Temporal variance not a robust } \\
\text { indicator (Dakos et al. 2012); } \\
\text { spatial variance may be } \\
\text { unreliable (Génin et al. 2018) }\end{array}$ & $\begin{array}{l}\text { Temporal variance does not relate to threshold } \\
\text { proximity (Veraart et al. 2012) (yeast } \\
\text { populations), but spatial variance was a good } \\
\text { indicator (Eby et al. 2017) (plant communities) }\end{array}$ \\
\hline $\begin{array}{l}\text { Self-regulation (Cabell } \\
\text { and Oleofse, 2012) }\end{array}$ & $\begin{array}{l}\text { Degree to which a } \\
\text { function can maintain } \\
\text { itself }\end{array}$ & $\begin{array}{l}\text { Feedbacks such as density-dependence } \\
\text { make the function responsive and able to } \\
\text { adapt to changes }\end{array}$ & $\begin{array}{l}\text { Recovery by being able } \\
\text { to adjust to variable } \\
\text { conditions }\end{array}$ & $\begin{array}{l}\text { Self-regulation is positively } \\
\text { related to function persistence } \\
\text { and ecological integrity (Mora et } \\
\text { al. 2017) }\end{array}$ & $\begin{array}{l}\text { Self-regulation by ecosystem engineers benefits } \\
\text { persistence of soil fertility (McKey et al. 2010) } \\
\text { (soil fertility) }\end{array}$ \\
\hline $\begin{array}{l}\text { Exposure to } \\
\text { disturbance (Cabell } \\
\text { and Oleofse, 2012) }\end{array}$ & $\begin{array}{l}\text { Function is exposed to } \\
\text { frequent, low-intensity } \\
\text { disturbances }\end{array}$ & $\begin{array}{l}\text { Small disturbances foster the ability of } \\
\text { function providers to maintain the } \\
\text { function under further disturbance }\end{array}$ & $\begin{array}{l}\text { Resistance and recovery } \\
\text { through adaptation to } \\
\text { disturbance }\end{array}$ & & $\begin{array}{l}\text { Microbial organisms that survive after freezing } \\
\text { can adapt to changed temperature conditions } \\
\text { (Stres et al. 2010) (microbial respiration) }\end{array}$ \\
\hline $\begin{array}{l}\text { Local coupling (Cabell } \\
\text { and Oleofse, 2012) }\end{array}$ & $\begin{array}{l}\text { Function relies on local } \\
\text { resources / interactions } \\
\text { (few imports) and } \\
\text { produces little waste } \\
\text { (few exports) }\end{array}$ & $\begin{array}{l}\text { Functions are supported by species and } \\
\text { resources that are adapted to the } \\
\text { (historic) range of local disturbances and } \\
\text { do not depend on external inputs/outputs }\end{array}$ & $\begin{array}{l}\text { Resistance and recovery } \\
\text { through local adaptation } \\
\text { to disturbance }\end{array}$ & & $\begin{array}{l}\text { Vanilla production outside its native range relies } \\
\text { on (human) hand pollination due to the absence } \\
\text { of native pollinators (Garibaldi et al. 2009) } \\
\text { (pollination) }\end{array}$ \\
\hline
\end{tabular}


(a)

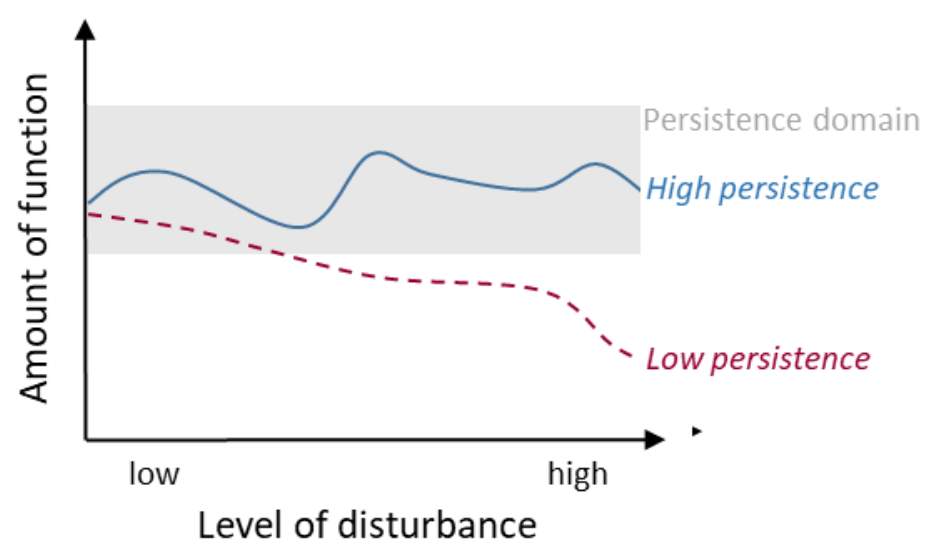

(b)

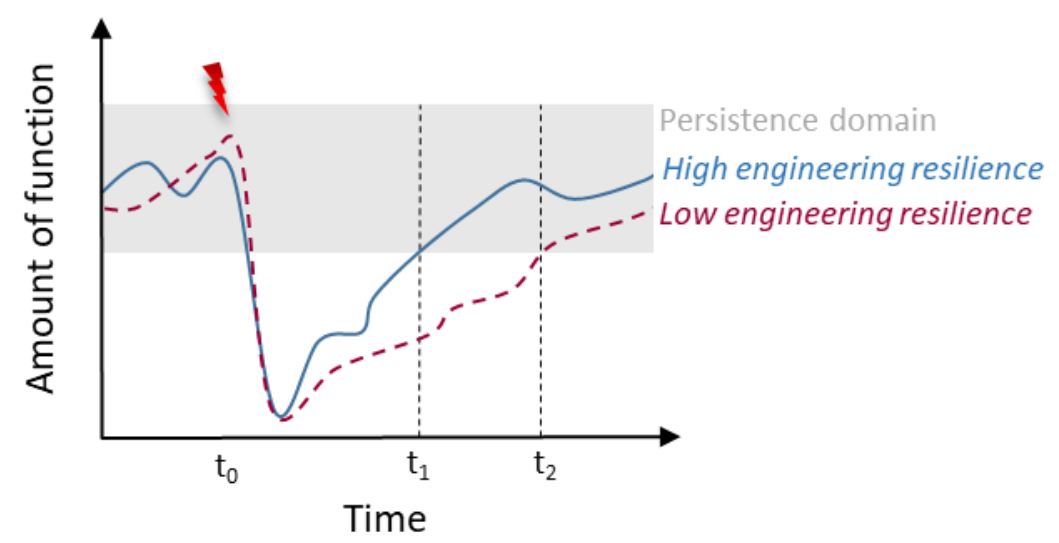

(c)

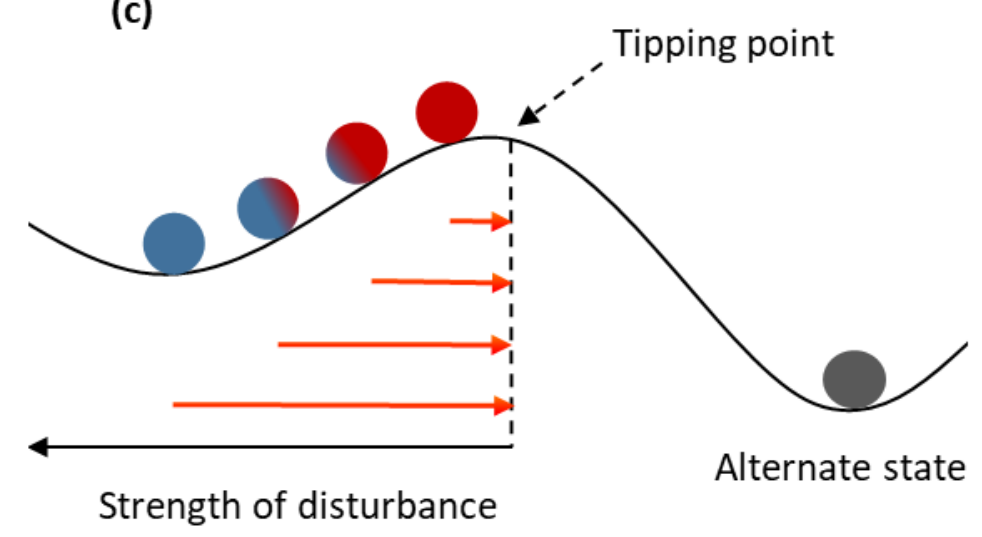

2145

Figure 1 


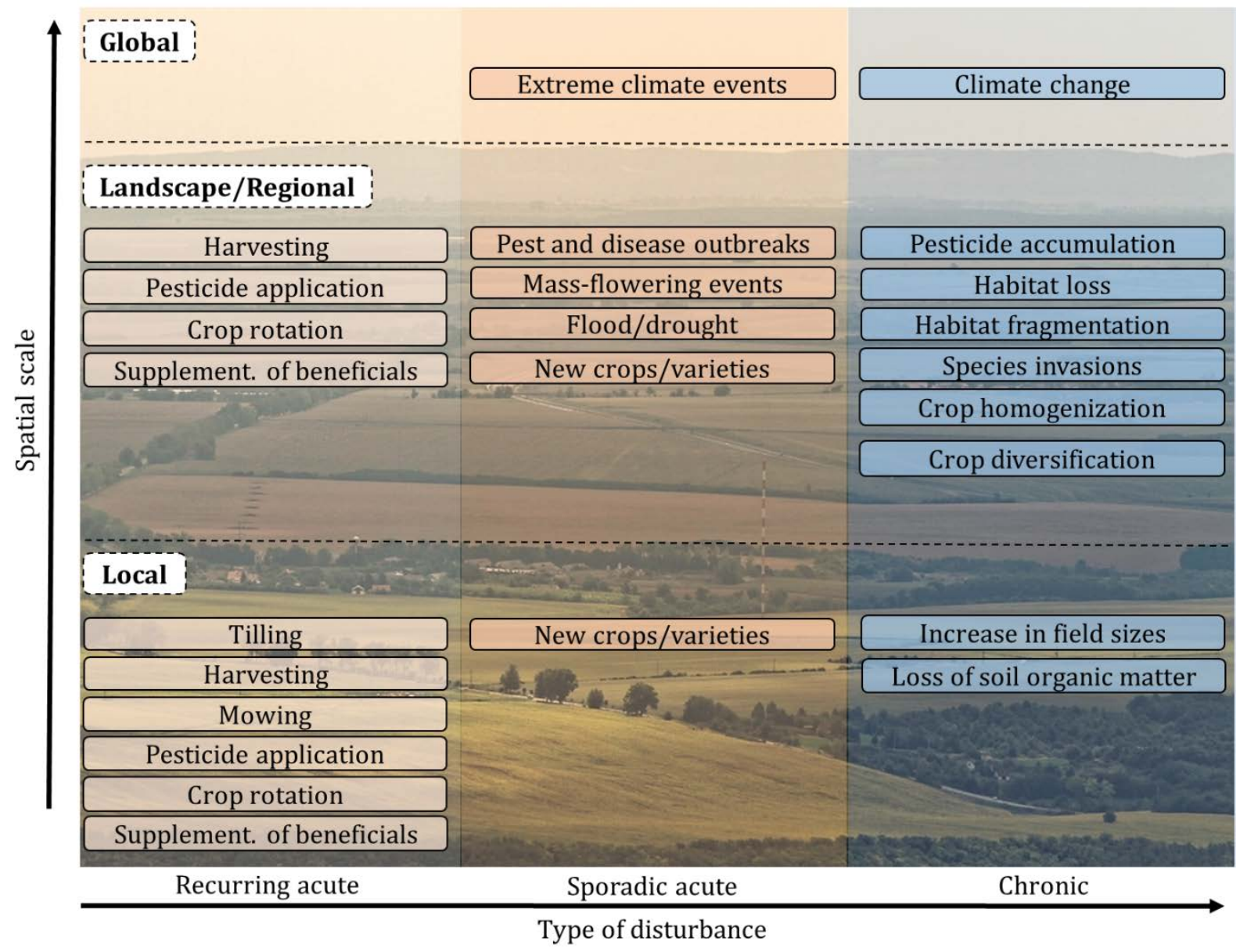

Figure 2 

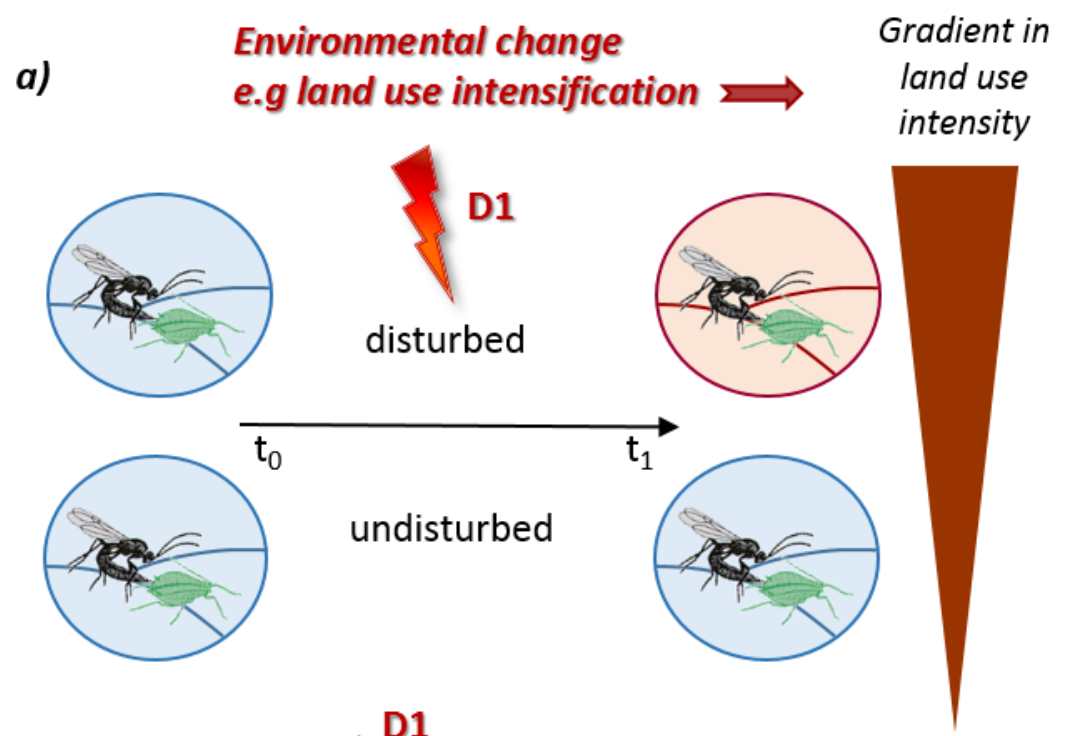

b)

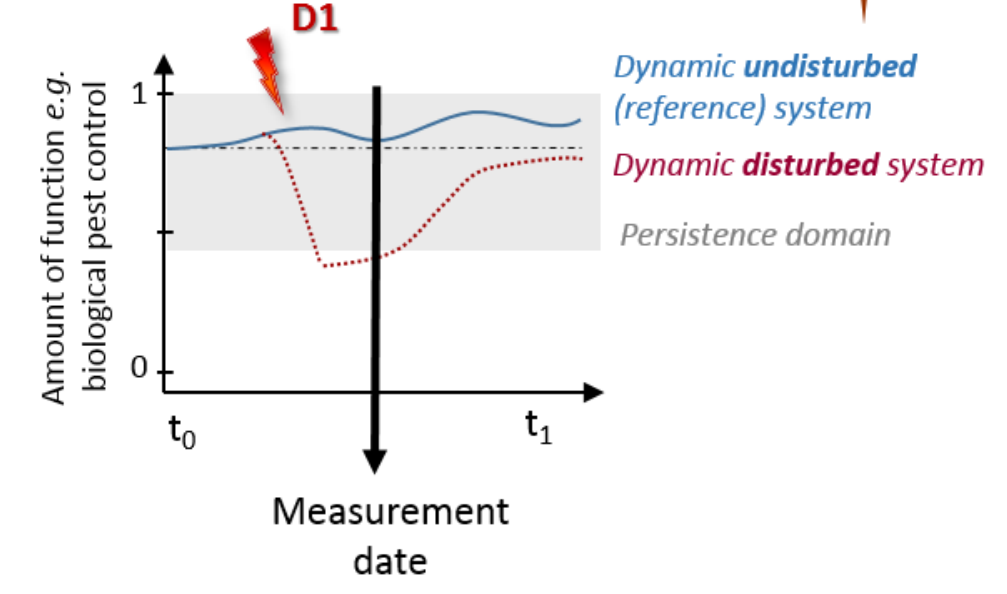

Figure 3 

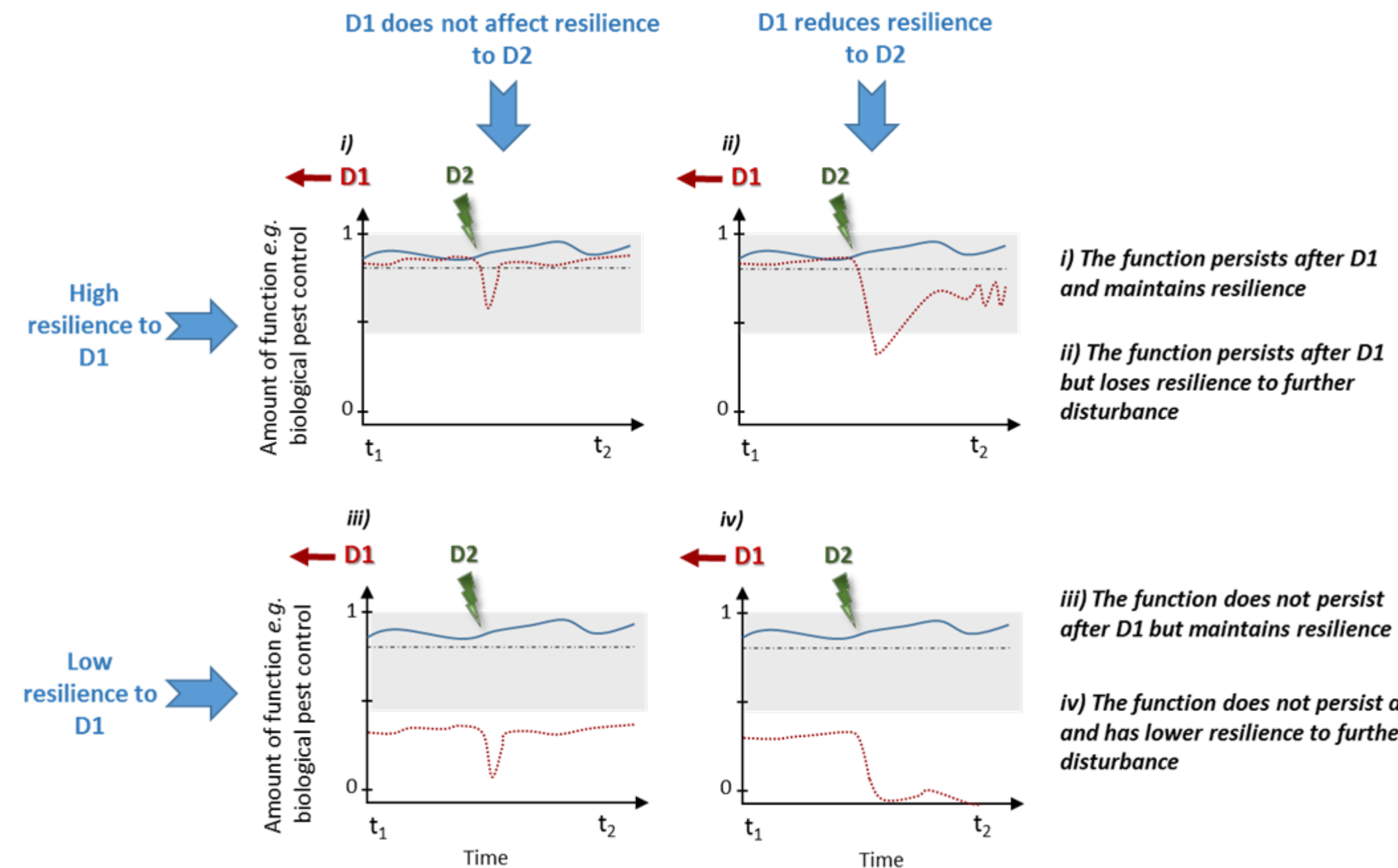

iv)

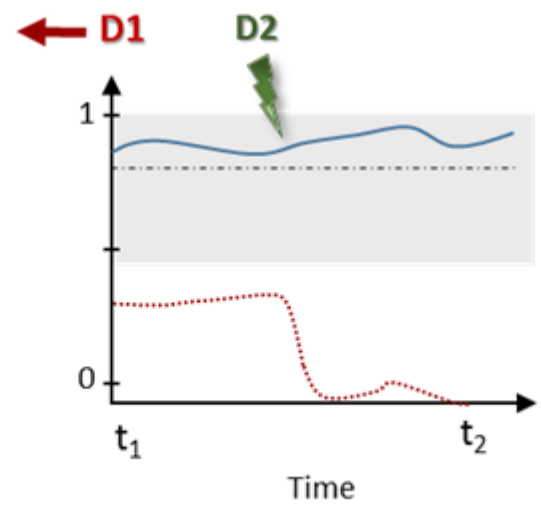

iii) The function does not persist after D1 but maintains resilience

iv) The function does not persist after D1 and has lower resilience to further disturbance 